(2) norden 



\section{Macroeconomic Framework Conditions and the Management of Research and Development in the Nordic Countries}

Authors: Svend Jespersen, senior analyst, Ph.D., CEBR; and Per Svejstrup Hansen, associate analyst, Ph.D, CEBR

Project leader: Svend E. Hougaard Jensen, professor, Ph.D, CEBR

TemaNord 2005:586 
Macroeconomic Framework Conditions and the

Management of Research and Development in the Nordic Countries

TemaNord 2005:586

(C) Nordic Council of Ministers, Copenhagen 2005

ISBN 92-893-1244-0

Only available as Print on Demand

This publication can be ordered on www.norden.org/order. Other Nordic publications are available at www.norden.org/publications

Nordic Council of Ministers

Store Strandstræde 18

DK-1255 Copenhagen K

Phone (+45) 33960200

Fax (+45) 33960202

\section{Nordic Council}

Store Strandstræde 18

DK-1255 Copenhagen K

Phone (+45) 33960400

Fax (+45) 33111870

www.norden.org

Authors: Svend Jespersen, senior analyst, Ph.D., CEBR and Per Svejstrup Hansen, associate analyst, Ph.D, CEBR

Project leader: Svend E. Hougaard Jensen, professor, Ph.D, CEBR, shj.cebr@cbs.dk

CEBR - Centre For Economic and Business Research

Copenhagen Business School

Porcelaenshaven 24B, DK-2000 Frederiksberg

$\mathrm{T}:+4538153479$

$\mathrm{F}:+4538153499$

W: www.cebr.dk

This report is prepared for the Nordic Council of Ministers. The findings, interpretations, and conclusions expressed in this report are entirely those of the authors. They do not necessarily represent the views of the Nordic Council of Ministers or of CEBR. Helpful comments from Svend E. Hougaard Jensen, Jakob R. Munch and Nikolaj Malchow-Møller are gratefully acknowledged. The report was prepared in collaboration with Nordic partners. Thanks to Thomas Andersson, IKED, Olof Ejermo, IKED, Thorvaldur Finnbjørnsson, Rannis, Per Koch, NIFU STEP, Juha Oksanen, VTT, and Arnold Verbeek, IDEA Consult for their contributions to this project. Thanks also to Ebbe K. Graversen, Danish Centre for Studies in Research and Research Policy for help and assistance in providing and analyzing the data used for this report.

\section{Nordic co-operation}

Nordic co-operation, one of the oldest and most wide-ranging regional partnerships in the world, involves Denmark, Finland, Iceland, Norway, Sweden, the Faroe Islands, Greenland and Åland. Cooperation reinforces the sense of Nordic community while respecting national differences and similarities, makes it possible to uphold Nordic interests in the world at large and promotes positive relations between neighbouring peoples.

Co-operation was formalised in 1952 when the Nordic Council was set up as a forum for parliamentarians and governments. The Helsinki Treaty of 1962 has formed the framework for Nordic partnership ever since. The Nordic Council of Ministers was set up in 1971 as the formal forum for co-operation between the governments of the Nordic countries and the political leadership of the autonomous areas, i.e. the Faroe Islands, Greenland and Åland. 


\section{Table of Contents}

Preface

Terms of Reference

1 Introduction

2 Framework conditions: Importance, measurement and indicators 25

2.1 Why are the framework conditions important?

3 Measurement and Main Indicators of R\&D and Innovation Activities in the Nordic Countries

3.1 Inputs into the Knowledge Producing System $\mathrm{n}$ the Nordic Countries

3.2 Outputs of the Knowledge Producing System in the Nordic Countries

4 Public Sector Research in the Nordic Countries

4.1 Description of the Public Knowledge System in the Nordic Countries

4.2 Challenges and Changes in the Public Knowledge System

in the Nordic Countries

5 The Common Innovation Infrastructure for Private Sector

Research in the Nordic Countries

5.1 Framework conditions and R\&D output - results from a Danish case study

6 Common Nordic initiatives 


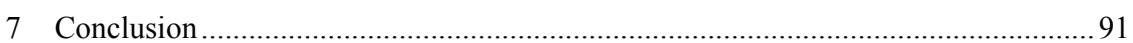

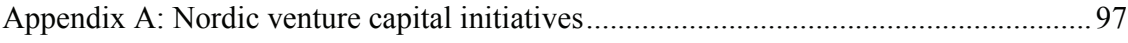

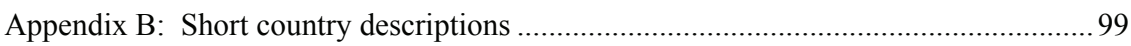

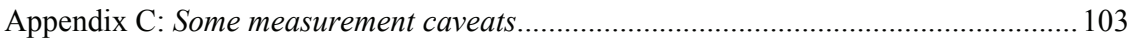

Appendix D: Short descriptions of the public knowledge system

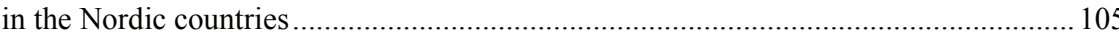

Appendix E: An econometric investigation of the Patents-R\&D relationship for Denmark

Appendix F: Svend E. Hougaard Jensen's presentation at seminar in the Danish Ministry of Finance 16 September 2005. 


\section{Preface}

This report is prepared for the Nordic Council of Ministers. The findings, interpretations, and conclusions expressed in this report are entirely those of the authors. They do not necessarily represent the views of the Nordic Council of Ministers or of CEBR. Helpful comments from Svend E. Hougaard Jensen, Jakob R. Munch and Nikolaj MalchowMøller are gratefully acknowledged. The report was prepared in collaboration with Nordic partners. Thanks to Thomas Andersson, IKED, Olof Ejermo, IKED, Thorvaldur Finnbjørnsson, Rannis, Per Koch, NIFU STEP, Juha Oksanen, VTT, and Arnold Verbeek, IDEA Consult for their contributions to this project. Thanks also to Ebbe K. Graversen, Danish Centre for Studies in Research and Research Policy for help and assistance in providing and analyzing the data used for this report. 



\section{Terms of Reference}

This project is performed for the Nordic Council of Ministers, acting through the Danish Ministry of Finance. The task is to describe the Nordic Innovation Systems and analyze the importance of a broad range of framework conditions for R\&D input and output.

The project has been carried out from 1 March 2005 to 30 September 2005. The results are delivered in the form of a report and have been presented at a seminar in the Danish Ministry of Finance the $16^{\text {th }}$ September 2005. 



\section{Sammenfatning}

I de senere år er den økonomisk politiske debat i en række vestlige lande i stigende grad kommet til at omhandle forskning og udvikling. Det skyldes bl.a., at flere og flere områder oplever en stigende globalisering og international konkurrence. I en sådan situation leder arbejdskraften efter politiktiltag, der kan sikre beskæftigelse og løn i fremtiden, arbejdsgivere leder efter tiltag, der kan fastholde og styrke konkurrenceevnen og lokale og nationale politikere efterspørger måder, hvorpå deres skattebase kan fastholdes.

Forskning og udvikling kan være et vigtigt bidrag i forhold til at sikre beskæftigelse, konkurrenceevne og skattegrundlag i fremtiden. En række økonomiske betragtninger taler for, at det samfundsøkonomiske afkast af forskning og udvikling overstiger det privatøkonomiske afkast med 50100 pct., jf. Mohnen (1996). Hertil kommer, at selv konservative skøn på de privatøkonomiske afkast af forskning og udvikling peger i retning af, at dette afkast er stort, i omegnen af 7-14 pct., jf. Jones og Williams (1998).

EUs medlemslande er enedes om inden 2010 at bringe de nationale udgifter til forskning og udvikling på et niveau svarende til 3 pct. af BNP, den såkaldte "Barcelona målsætning". Blandt de nordiske lande er det $\mathrm{i}$ øjeblikket kun Finland, Island og Sverige, der opfylder målsætningen, mens Danmark mangler noget og Norge er langt fra at opfylde målsætningen.

Barcelona målsætningen er en udgiftsmålsætning. Set fra et velfærdsøkonomisk perspektiv burde fokus i stedet være på, hvordan en indsats i forhold til forskning og udvikling gavner de europæiske og nordiske befolkninger mest. Dette taler for at formulere målsætninger for nationalindkomst pr. capita, for den erhvervsmæssige anvendelse af offentlig forskning, for den videnskabelige produktion mv.

For at sikre, at det samfundsmæssige afkast af en øget forsknings- og udviklingsindsats bliver højt, er det nødvendigt at identificere de rammebetingelser, der giver private og offentlige aktører en tilskyndelse til at engagere sig i forskning og udvikling, og de rammebetingelser, der sikrer en høj kvalitet og værdi af indsatsen. Sådanne rammebetingelser kan være adgang til højtkvalificeret arbejdskraft, adgang til finansiering, samt hvorvidt innovationssystemet $i$ bred forstand er hensigtsmæssigt indrettet $i$ forhold til at sikre en hensigtsmæssig brug af forsknings- og udviklingsmidler.

Nærværende projekt belyser ovennævnte rammebetingelser ud fra et Nordisk perspektiv. Projektet tilvejebringer en del af den nødvendige viden for at kunne besvare spørgsmål om, hvordan der kan sikres et fort- 
sat højt afkast af offentlig forsknings- og udviklingsindsats. Den nuværende indsats og de nuværende resultater i de nordiske lande belyses, og der gennemføres teoretiske og empiriske analyser af betydningen af rammevilkår for såvel indsats som resultater.

\section{Særtræk ved de nordiske lande i en forsknings- og udviklingssammenhæng}

De nordiske lande har det til fælles, at de er små åbne økonomier, og de er højt økonomisk udviklet. Hertil kommer, at der er mange fællestræk i de måder, de har valgt at udforme deres offentlige videnssystemer på.

De nordiske lande er indbyrdes meget forskellige med hensyn til størrelse og befolkningstæthed. Bortset fra Danmark har de nordiske lande generelt lav befolkningstæthed. Norge har betydelige ressourcer af olie og vandkraft, mens Finland og Sverige har adgang til store ressourcer af skov og Island har store ressourcer af fisk i Atlanterhavet.

\section{Situationen i de nordiske lande}

Den generelle økonomiske situation i de nordiske lande er god. Nationalindkomsten pr. capita er høj, ledigheden er forholdsvis lav, inflationen er lav, de offentlige budgetter er forholdsvis stærke og den internationale konkurrenceevne er høj.

En måde at opsummere den generelle økonomiske situation på er ved hjælp af det såkaldte globale konkurrenceevneindeks, jf. tabel 1. Dette indeks sammenfatter information om en økonomis generelle makroøkonomiske situation, kvaliteten af offentlige institutioner og teknologisk udviklingsparathed. Ifølge denne indikator hører de nordiske lande til den internationale elite.

De nordiske lande er generelt dygtige til at producere videnskabelig viden og formidle den i videnskabelige tidsskrifter, som det ses af tabel 2 neden for. I en sammenligning med en række af de lande, de nordiske lande ofte sammenlignes med, ligger de nordiske lande i top. Der bør dog tages forbehold for, at antallet af citationer af de publicerede artikler ikke er kendt, og derfor vides det ikke, hvor stor videnskabelig gennemslagskraft, den videnskabelige produktion har. 
Tabel 1 Globalt konkurrenceevneindeks (GCl)

\begin{tabular}{lrrr}
\hline Country & GCl 2004 placering & GCl 2004 score & GCl 2003 placering \\
\hline Finland & 1 & 5.95 & 1 \\
USA & 2 & 5.82 & 2 \\
Sverige & 3 & 5.72 & 3 \\
Taiwan & 4 & 5.69 & 5 \\
Danmark & 5 & 5.66 & 4 \\
Norge & 6 & 5.56 & 9 \\
Singapore & 7 & 5.56 & 6 \\
Schweiz & 8 & 5.49 & 7 \\
Japan & 9 & 5.48 & 11 \\
Island & 10 & 5.44 & 8 \\
Storbritannien & 11 & 5.30 & 15 \\
Holland & 12 & 5.30 & 12 \\
Tyskland & 13 & 5.28 & 13 \\
Australien & 14 & 5.25 & 10 \\
Canada & 15 & 5.23 & 16 \\
Forenede Arabiske Emirater & 16 & 5.21 &. \\
Østrig & 17 & 5.20 & 17 \\
New Zealand & 18 & 5.18 & 14 \\
Israel & 19 & 5.09 & 20 \\
Estland & 20 & 5.08 & 22 \\
\hline
\end{tabular}

Kilde: World Economic Forum, Global Competitiveness Report, 2004-05

Med hensyn til kommercialiseringen af viden er billedet mere sammensat. Mens Finland og Sverige hører til den internationale top i forhold til antallet af patenter pr. indbygger, ligger Danmark over gennemsnittet, men dog et stykke fra toppen, og Norge og Island ligger under OECD og EU-gennemsnittet. I forhold til andre lande, som de nordiske lande ofte sammenlignes med, klarer Danmark sig relativt dårligt med hensyn til udtagningen af patenter, jf. tabel 3.

Tabel 2 Videnskabelige artikler pr. million indbyggere

\begin{tabular}{lll}
\hline & $\mathbf{1 9 9 5}$ & $\mathbf{2 0 0 1}$ \\
\hline Danmark & 843 & 931 \\
Finland & 809 & 983 \\
Island & 591 & 610 \\
Norge & 678 & 721 \\
Sverige & 1.052 & 1.159 \\
\hline Frankrig & 493 & 514 \\
Tyskland & 467 & 530 \\
Japan &. & 451 \\
Holland & 798 & 786 \\
USA & 762 & 705 \\
\hline
\end{tabular}

Anm.: Tyskland er inklusive artikler fra Østtyskland før 1992. Videnskabelige artikler dækker over "science and engineering".

Kilde: OECD Science, Technology and Industry Outlook 2004, Paris 
Tabel 3 Patentaktivitet i de nordiske lande

\begin{tabular}{|c|c|c|c|c|c|c|c|c|}
\hline & \multicolumn{4}{|c|}{ Patentansøgninger } & \multicolumn{4}{|c|}{ Patenter tildelt } \\
\hline & \multicolumn{2}{|c|}{$\begin{array}{c}\text { EPO } \\
\text { højteknologi }\end{array}$} & \multicolumn{2}{|c|}{ EPO } & \multicolumn{2}{|c|}{$\begin{array}{c}\text { USPTO } \\
\text { højteknologi }\end{array}$} & \multicolumn{2}{|c|}{ USPTO } \\
\hline & 1996 & 2002 & 1996 & 2002 & 1996 & 2002 & 1996 & 2002 \\
\hline \multicolumn{9}{|c|}{---------- Pr. million indbyggere ----------- } \\
\hline Danmark & 13 & 45 & 130 & 215 & 5 & 16 & 48 & 84 \\
\hline Finland & 49 & 120 & 174 & 311 & 15 & 51 & 87 & 159 \\
\hline Island & 2 & 43 & 30 & 122 & 0 & 22 & 17 & 58 \\
\hline Norge & 5 & 23 & 87 & 131 & 3 & 6 & 31 & 55 \\
\hline Sverige & 36 & 75 & 218 & 312 & 17 & 38 & 97 & 187 \\
\hline Frankrig & 12 & 32 & 100 & 147 & 8 & 12 & 48 & 68 \\
\hline Tyskland & 16 & 45 & 178 & 301 & 7 & 16 & 84 & 137 \\
\hline Japan & 22 & 40 & 101 & 167 & 50 & 75 & 184 & 274 \\
\hline Holland & 23 & 93 & 136 & 279 & 11 & 15 & 52 & 87 \\
\hline USA & 24 & 48 & 107 & 155 & 41 & 76 & 231 & 301 \\
\hline
\end{tabular}

Anm.: EPO er European Patent Office. USPTO er United States Patent and Trademarks Office Kilde: Trendchart Scoreboard 2004.

En anden indikator er andelen af virksomhedernes omsætning, der stammer fra salget af produkter, der enten er nye for virksomheden, der introducerer dem, eller nye for markedet, hvorpå de introduceres. Tabel 4 viser denne indikator for de nordiske lande sammenlignet med en række af de lande, de normalt sammenlignes med.

Det viser sig, at målt ved andelen af omsætningen, der skabes ved salg af nye produkter, er Finland det eneste nordiske land, der klarer sig bedre end EU-gennemsnittet. Danmark klarer sig lidt dårligere end EUgennemsnittet (ca. 23 pct.), mens der ikke er oplysninger for Sverige på denne indikator. Island og Norge klarer sig markant dårligere end gennemsnittet, målt på denne indikator.

Tabel 4 Andel af omsætning skabt ved salg af produkter, der er nye på markedet eller for den enkelte virksomhed, pct.

\begin{tabular}{lr}
\hline & $\mathbf{2 0 0 3}$ \\
\hline Danmark & 20,1 \\
Finland & 32,0 \\
Island & 4,9 \\
Norge & 8,4 \\
Sverige &. \\
\hline Frankrig & 17,5 \\
Tyskland & 29,7 \\
Japan &. \\
Holland & 17,7 \\
USA &. \\
\hline
\end{tabular}

Kilde: Trendchart Scoreboard 2004. 
Figur 1 Doktorgrader pr. mio. indbyggere i de nordiske lande

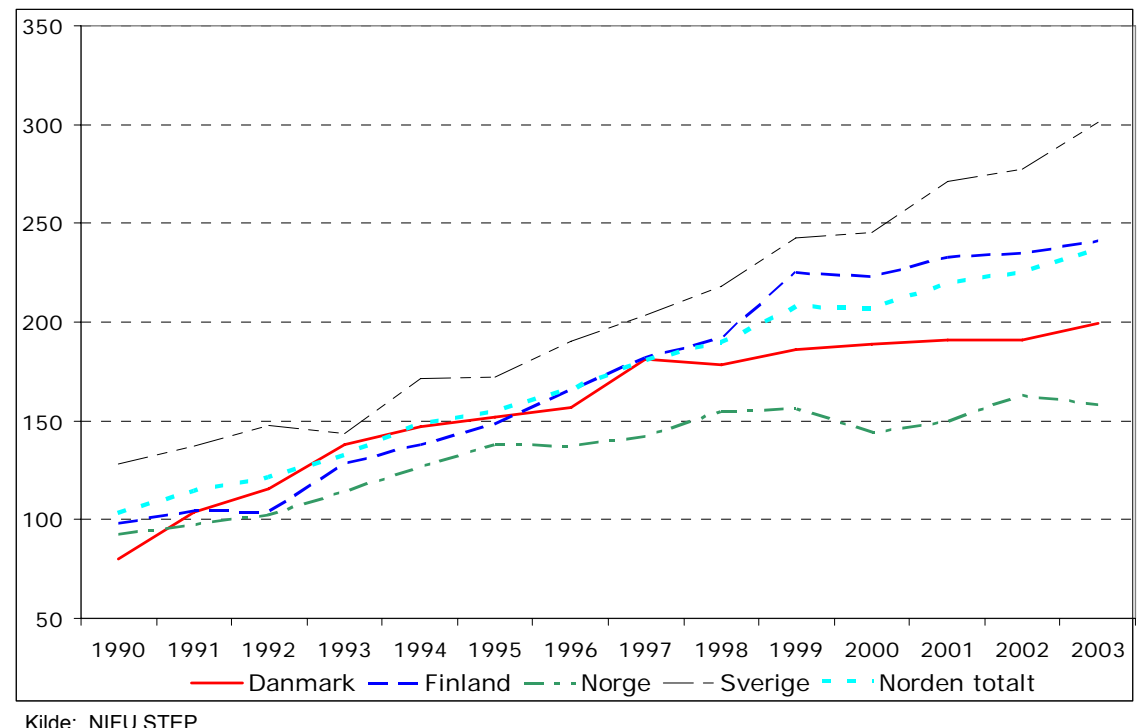

Tabel 5 Samlede F\&U udgifter, pct. af BNP

\begin{tabular}{|c|c|c|c|c|c|c|c|}
\hline & 1985 & 1989 & 1993 & 1997 & 2001 & 2002 & 2003 \\
\hline & & & נו-נינו & Pct. -..- & - & & \\
\hline \multirow{2}{*}{$\begin{array}{l}\text { Danmark } \\
\text { Finland }\end{array}$} & 1,21 & 1,51 & 1,74 & 1,94 & 2,41 & 2,53 & \\
\hline & 1,56 & 1,81 & 2,16 & 2,71 & 3,41 & 3,44 & 3,49 \\
\hline Island & 0,74 & 1,02 & 1,35 & 1,88 & 3,06 & 3,09 & 3,04 \\
\hline \multirow{2}{*}{$\begin{array}{l}\text { Norge } \\
\text { Sverige }\end{array}$} & 1,48 & 1,68 & 1,72 & 1,64 & 1,6 & 1,67 & 1,75 \\
\hline & 2,78 & 2,80 & 3,17 & 3,54 & 4,27 & & 3,98 \\
\hline Frankrig & 2,22 & 2,29 & 2,40 & 2,22 & 2,23 & 2,26 & 2,19 \\
\hline & 2,68 & 2,79 & 2,33 & 2,29 & 2,51 & 2,53 & 2,55 \\
\hline Japan & 2,75 & 2,89 & 2,83 & 2,84 & 3,07 & 3,12 & 3,15 \\
\hline Holland & 1,99 & 2,04 & 1,93 & 2,04 & 1,88 & 1,80 & \\
\hline USA & 2,75 & 2,61 & 2,52 & 2,58 & 2,73 & 2,66 & 2,60 \\
\hline
\end{tabular}

Kilde: OECD Database, Science and Technology.

En indikator for output fra den offentlige del af innovationssystemet er produktionen af forskeruddannede, jf. figur 1. Der er stor forskel mellem udviklingen i de nordiske lande, målt på denne indikator. I Sverige og Finland er antallet af forskeruddannede steget kraftigt i de seneste år, mens væksten har været langsommere i Danmark og der nærmest har været nulvækst i Norge.

Alle de nordiske lande, bortset fra Norge, bruger en større andel af BNP i forskning og udvikling, end de fleste lande, de normalt sammenlignes med, jf. tabel 5, og målt ved indsatsen af menneskelige ressourcer i forskning og udvikling er indsatsen i alle nordiske lande over gennemsnittet for EU. Antallet af forskere i forhold til antallet af indbyggere er også generelt højt i de nordiske lande i en international sammenligning. 


\section{Rammevilkår: Den offentlige sektor}

De nordiske lande deler en række træk med hensyn til indretningen af den offentlige del af innovationssystemet. Videninstitutioner er bl.a. universiteter, sektorforskningsinstitutter, Godkendte Teknologiske Serviceinstitutter (GTS) mv. Universiteterne udfører forskning, undervisning og vidensoverførsel. Sektorforskningsinstitutter udfører forskning rettet mod rådgivning af den offentlige sektor. Sektorforskningen er typisk placeret under et bestemt ministerium. Ud over forskning gennemfører sektorforskningsinstitutioner en række rådgivnings- og moniteringsopgaver. GTS-institutter tilbyder rådgivning til virksomheder mod betaling. Videninstitutionerne skaber viden gennem forskning og tiltrækker viden fra udlandet og fra andre sektorer i økonomien gennem ansættelse af akademisk personnel, deltagelse i konferencer mv. Videninstitutionerne videreformidler deres viden gennem uddannelse, samarbejde med virksomheder og den offentlige sektor, via forbindelser til forskerparker mv.

Ud over videninstitutionerne har de nordiske lande også til fælles, at de har forskningsråd, der finansierer forskning samt rådgiver det offentlige om videnskabspolitik og prioriteringen af de offentlige forskningsmidler.

Der er dog markante forskelle mellem, hvordan de nordiske lande uddeler forskningsmidler, jf. tabel 6 . Finland finansierer en stor del af forskningen, 42 pct., gennem forskningsrådene, mens Danmark kun finansierer en mindre del af forskningen, 12 pct., på denne måde.

Tabel 6 Statslige bevillinger til F\&U, fordelt på modtagere i Norden, 2005, pct. af samlede bevillinger

\begin{tabular}{lccccc}
\hline & $\begin{array}{c}\text { Basis- } \\
\text { bevillinger, } \\
\text { universitetet og } \\
\text { lignende }\end{array}$ & $\begin{array}{r}\text { Andre } \\
\text { forsknings- } \\
\text { institutioner }\end{array}$ & Forskningsråd & $\begin{array}{r}\text { Andre } \\
\text { programmer }\end{array}$ & $\begin{array}{r}\text { Udlandet/ } \\
\text { internationale } \\
\text { organisationer }\end{array}$ \\
Danmark & 51 & 15 & 12 & 17 & 5 \\
Finland & 29 & 16 & 42 & 13 & 4 \\
Island & 37 & 33 & 18 & 8 & 6 \\
Norge & 42 & 10 & 30 & 11 & 1 \\
Sverige & 43 & 38 & 18 &. & 2 \\
\hline Total & 41 & 23 & 25 & 8 & 4 \\
\hline
\end{tabular}

Kilde: Nordisk Ministerråd (2005).

Der er også markante forskelle med hensyn til den del af forskningsmidlerne, der tilflyder almenvidenskabelige formål eller kanaliseres ud til enkeltsektorer i økonomien, jf. tabel 7. I Danmark anvendes 70 pct. af de offentlige forskningsmidler på almenvidenskabelige formål, mens den tilsvarende andel er 17 pct. i Island. 
Der er også store forskelle på, hvordan universiteterne i de nordiske lande fordeler forskningsmidlerne på hovedområder, jf. tabel 8. Danmark og Finland bruger størstedelen af forskningsmidlerne på naturvidenskab, mens Sverige og Norge bruger størstedelen på forskning inden for medicinområdet.

Tabel 7 Statslige bevillinger til F\&U, fordelt på specifikke programmer i Norden, 2005, pct.

\begin{tabular}{|c|c|c|c|c|c|}
\hline & $\begin{array}{r}\text { Primære } \\
\text { erhverv }\end{array}$ & Industri & $\begin{array}{r}\text { Offentlig } \\
\text { service }\end{array}$ & $\begin{array}{r}\text { Almenviden- } \\
\text { skabelig } \\
\text { udvikling }\end{array}$ & $\begin{array}{r}\text { Forsvar og } \\
\text { rumforskning }\end{array}$ \\
\hline & & - & Pct. --.---..- & --------- & \\
\hline Danmark & 6 & 7 & 13 & 70 & 3 \\
\hline Finland & 6 & 26 & 21 & 41 & 5 \\
\hline Island & 17 & 1 & 65 & 17 & 0 \\
\hline Norge & 9 & 8 & 23 & 52 & 9 \\
\hline Sverige & 2 & 5 & 15 & 57 & 21 \\
\hline Total & 5 & 11 & 19 & 54 & 11 \\
\hline
\end{tabular}

Kilde: Nordisk Ministerråd (2005).

Tabel 8 Højere uddannelsesinstitutioners F\&U-udgifter fordelt på hovedområde, pct., 2001

\begin{tabular}{|c|c|c|c|c|c|}
\hline & Danmark & Finland & Island & Norge & Sverige \\
\hline & & \multicolumn{4}{|c|}{ - Pct. - -- } \\
\hline Naturvidenskab & 31,4 & 27,5 & 19,9 & 20,6 & 18,4 \\
\hline Teknik & 14,9 & 20,2 & 33,8 & 11,8 & 25,5 \\
\hline Medicin & 13,3 & 24,1 & 12,0 & 29,8 & 28,6 \\
\hline Jordbrugsvidenskab & 6,7 & 2,0 & 8,5 & 5,2 & 5,3 \\
\hline Samfundsvidenskab & 17,3 & 17,9 & 15,6 & 21,7 & 13,1 \\
\hline Humaniora & 16,5 & 8,3 & 10,1 & 10,9 & 6,0 \\
\hline Total & 100,0 & 100,0 & 100,0 & 100,0 & 100,0 \\
\hline
\end{tabular}

Kilde: OECD

Tabel 9 Statslige bevillinger til F\&U i de nordiske lande, pct.

\begin{tabular}{|c|c|c|c|c|}
\hline & \multicolumn{2}{|c|}{ Andel af statens budget } & \multicolumn{2}{|c|}{ Andel af BNP } \\
\hline & 2000 & 2005 & 2000 & 2005 \\
\hline & \multicolumn{4}{|c|}{-.o-n } \\
\hline Danmark & 3,0 & 2,8 & 0,77 & 0,73 \\
\hline Finland & 4,6 & 4,5 & 1,00 & 1,04 \\
\hline Island & 11,9 & 12,6 & 0,93 & 0,95 \\
\hline Norge & 1,6 & 1,5 & 0,66 & 0,77 \\
\hline Sverige & 2,3 & 3,3 & 0,70 & 0,90 \\
\hline
\end{tabular}

Kilde: NIFU STEP

Centrale træk ved udviklingen i de senere år i offentlig forskning og udvikling er, at forskningsmidlerne i stigende grad er blevet kanaliseret gennem forskningsråd og med et strategisk formål. Med hensyn til forsk- 
ningsbevillingerne for 2005 har Danmark som det eneste nordiske land reduceret de offentlige udgifter til forskning og udvikling som andel af det samlede offentlige budget og i forhold til BNP, som det fremgår af tabel 9.

\section{Rammevilkår: Den private sektor}

Der er meget empirisk belæg for, at det privatøkonomiske afkast til forskning og udvikling er højt, og at det samfundsøkonomiske afkast er endnu højere. Forsigtige skøn på det privatøkonomiske afkast til investeringer i forskning og udvikling ligger mellem 7 og 14 pct., jf. Jones and Williams (1998).

Der er således gode principielle argumenter for offentlig støtte til forskning og udvikling. Alle nordiske lande anvender også forskellige former for tiltag til at understøtte forskning og udvikling, nogle eksempler er skattefradrag for private virksomheders forskning og udvikling eller offentlig støtte til venture capital.

En række nyere undersøgelser har fundet belæg for, at subsidier til forskning og udvikling og skattefradrag for forskning og udvikling bidrager til at øge den private sektors forsknings- og udviklingsudgifter. Offentlige initiativer i form af GTS-institutter har også en statistisk signifikant positiv effekt på den private sektors forsknings- og udviklingsudgifter. Omvendt er der ikke statistisk sikre tegn på, at styrkede patentrettigheder medfører øget privat forskning og udvikling.

De nordiske landes erhvervsstrukturer er meget forskellige, og de har forskellig adgang til naturressourcer. Finland og Sverige har enkelte meget store virksomheder, der spiller en særlig rolle i landenes innovationssystemer. Norge er omvendt specialiseret i udvinding og udnyttelse af naturressourcer.

To centrale spørgsmål er, om forskellene i erhvervsstruktur påvirker virksomhedernes omfang af investering i forskning og udvikling, og om forskellene i erhvervsstruktur påvirker afkastet af investeringer i forskning og udvikling.

En række nyere undersøgelser finder, at meget lave eller meget høje niveauer af produktmarkedskonkurrence virker hæmmende for privat forskning og udvikling. Ligeledes kan offentlig regulering af produkt- og arbejdsmarkedet virke hæmmende for privat forskning og udvikling. Omvendt betyder tilstedeværelsen af store virksomheder, adgang til højtuddannet arbejdskraft, nærhed til offentlige forsknings- og udviklingsinstitutioner og adgang til kapital, at den private forsknings- og udviklingsindsats stiger. En anden faktor, der synes at være gavnlig for den private sektors forskning og udvikling, er tilstedeværelsen af multinationale virksomheder. Disse virksomheder har stor betydning for et lands mulighed 
for at tiltrække viden fra udlandet, og de øger konkurrencen på produktmarkedet.

Et case-studie baseret på en stikprøve af danske virksomheder koblet med oplysninger om erhvervsstruktur og beskæftigelsesstruktur i danske pendlingsoplande, finder, at produktmarkedskonkurrence øger virksomhedernes værditilvækst og at adgang til højtuddannet arbejdskraft øger afkastet af investeringer i forskning og udvikling. Industriel agglomeration er negativt korreleret med virksomhedernes værditilvækst. Et overraskende resultat af case-studiet er, at virksomheder placeret i oplande, hvor der er en stor koncentration af beskæftigelse i forsknings- og udviklingssektoren, ikke har højere afkast af deres investeringer i forskning og udvikling. Nærhed til højtkvalificeret arbejdskraft i form af forskningsog udviklingspersonnel kunne ellers forventes at øge effektiviteten af F\&U-aktiviteter, fordi der er adgang til højproduktiv arbejdskraft. Simulationsresultater baseret på undersøgelserne i case-studiet indikerer imidlertid, at subsidier til privat forskning og udvikling, og en øgning af antallet af personer med videregående uddannelse vil have en betydelig effekt på private virksomheders værditilvækst.

\section{Fællesnordiske udfordringer og vidensbehov}

De nordiske lande klarer sig generelt godt i forhold til at levere forskningsresultater af høj videnskabelig værdi, mens billedet er mere sammensat $i$ forhold til landenes evne til at anvende viden kommercielt. En række af de væsentligste udfordringer for de nordiske lande består i at forbedre den kommercielle anvendelse af videnskabelige resultater. Flere nordiske lande har formuleret målsætninger om, at universiteterne skal overføre deres viden til resten af økonomien, men der er ikke sket en tilpasning af incitamentsstrukturerne på universiteterne, således at akademisk personnel har et direkte økonomisk eller karrieremæssigt incitament til at deltage i vidensoverførsel. En væsentlig udfordring består $\mathrm{i}$ indretningen af incitamentsstrukturer, der sikrer den rette balance mellem universiteternes opgaver i forhold til forskning, undervisning og vidensoverførsel. I flere nordiske lande er det forsøgt at tilvejebringe incitamenter for videnskabeligt personnel til at kommercialisere viden ved at give forskere intellektuelle ejendomsrettigheder til den videnskabelige produktion. Principielle økonomiske betragtninger taler ikke nødvendigvis for, at denne tilgang er hensigtsmæssig. Monopoliseringen af viden gennem patentering skaber ikke nødvendigvis øget videnoverførsel. Nyere forskning peger i stedet på mekanismer som patent buyouts eller innovationskonkurrencer, hvor den offentlige sektor sikrer sig retten til den frembragte viden, som kan stilles frit til rådighed for alle, der ønsker at anvende den. 
En anden udfordring, der også er relateret til vidensoverførsel består i at finde den rette balance mellem på den ene side at skabe videnskabelige miljøer i regionerne, der kan bidrage til en regional videnspredning, og på den anden side at sikre tilstrækkelig kritisk masse til at sikre høj kvalitet i den videnskabelige produktion. I øje-blikket er der ikke undersøgelser af, hvordan denne balance bedst opnås, og det er nødvendigt at udvikle analyseredskaber hertil.

De europæiske lande har som mål, at der anvendes 3 pct. af bruttonationalproduktet på forskning og udvikling i 2010. For at sikre et højt samfundsmæssigt afkast af øgede udgifter til forskning og ud-vikling er det nødvendigt med analyser inden for flere områder.

Først og fremmest er det nødvendigt med flere analyser af afkastet af forskning og udvikling i de nordiske lande. For at kunne indrette den offentlige sektors forskning hensigtsmæssigt - og eventuelt øge den - er det nødvendigt at analysere, hvilke faktorer der medfører, at det marginale afkast af offentlige investeringer i forskning og udvikling bliver højt. Tilsvarende, hvis den offentlige sektor skal støtte den private sektors forskning og udvikling er det nødvendigt at vide, hvilke forhold der skal være opfyldt, for at afkastet af private investeringer i forskning og udvikling bliver højt. Der er desuden behov for analyser af, hvorledes stigende udgifter til forskning og udvikling påvirker lønningerne og den videnskabelige produktion for videnskabeligt personnel. Dette er særligt tilfældet for Danmark og Norge, der begge mangler meget i forhold til at opfylde Barcelona-målsætningen, men som ikke har øget antallet af forskeruddannede meget i de senere år.

Der er behov for analyser af, hvorledes øgede forskningsmidler skal fordeles. Der er kun få undersøgelser af, hvorvidt fordeling gennem forskningsråd er bedre end fordeling via universiteternes basisbevillinger. De gennemførte analyser tyder på, at fordeling af midlerne gennem forskningsråd er bedre end via basisbevillinger, men flere analyser på dette område er nødvendigt for at understøtte eller afkræfte de hidtil fundne resultater. Herudover er der behov for analyser af samspillet mellem supra-national forskning gennem f.eks. EU, og nationale bevillingssystemer.

Der er tegn på, at multinationale virksomheder spiller en vigtig rolle $\mathrm{i}$ den internationale overførsel af viden. Derfor er det vigtigt, at de nordiske lande er attraktive for multinationale virksomheder i forhold til etablering og investering. Hidtidige undersøgelser peger på forhold som kvaliteten af arbejdsstyrken som en afgørende faktor, men niveauet af et lands selskabsskatter har også en betydning for multinationale virksomheders tilbøjelighed til at etablere sig i landet.

De nordiske lande er alle meget åbne økonomier. Det indebærer, at der er forholdsvis god adgang til viden produceret i andre lande, bl.a. fordi viden er indlejret i produkter, der handles over landegrænserne. Det indebærer imidlertid også, at en stor del af den viden, der produceres i de 
nordiske lande hurtigt tilflyder andre lande. Der er et behov for forskning i, hvordan små åbne økonomier som de nordiske bedst deltager i den internationale vidensdeling, det vil bl.a. sige forskning i spørgsmål som optimal udformning af intellektuelle ejendomsrettigheder.

Generelt er forskning og udvikling et område, hvor der er et stort behov for en yderligere forskningsindsats, jf. ovenstående. 



\section{Introduction}

In recent years, the intensified globalization and the rapid technological progress have turned the focus of the economic debate in the developed countries towards issues of research and development (R\&D). Workers look for policies which can ensure high levels of employment and wages in a future where more areas of economic activity will be subjected to more intense competition. Employers look for policies which can increase their competitiveness. Local and national politicians look for ways to attract multinational companies to their region and to maintain the tax base.

$\mathrm{R} \& \mathrm{D}$, innovation, and knowledge diffusion may be an important part of the solution to these concerns as they are important sources to economic growth and increased productivity. Clear focus on these factors is at the forefront in EU's endeavors to fulfill the Lisbon criteria in order to make EU the world's most productive region.

The countries in the European Union have agreed to bring national research expenditures to a level of 3 per cent of GDP by 2010 - the socalled Barcelona Objective. At present, Sweden and Finland easily fulfill the expenditure requirements, whereas Denmark does not. Iceland will just satisfy the 3 per cent target, but Norway is some way from meeting the requirements, should these countries choose to adopt the objectives of the Barcelona Summit. The Barcelona Objective concerns national expenditure on $R \& D$, which is a measure of inputs or efforts. From a welfare economic perspective, however, emphasis should be put on outputs or results. R\&D objectives should thus be cast in terms of welfare measures such as national income per worker.

But how can we ensure a high return to increases in public and private R\&D spending? To answer this question, we need to look into the knowledge producing system and determine which framework conditions are required for companies and public institutions in order to encourage sufficient $R \& D$ while maintaining a high quality in the R\&D effort.

This report will look at the framework conditions conducive to successful R\&D activities. By framework conditions we mean the availability of input into R\&D, such as the amount of highly skilled personnel and sources of funding, as well as the general conduciveness/infrastructure of the innovation system, including the cooperation between the public and the private sector. The report will not deal with the R\&D process itself in public research institutions or in private businesses.

This project takes a Nordic perspective on answering the question of how to ensure a high return to increases in public and private $R \& D$ spending. The Nordic countries are similar in the sense that they are all 
small open economies and they are highly developed in an economic sense. Open economies are exposed to the conditions of the world market. Final goods, factors of production and knowledge flow easier to and from such economies than what is the case for less open economies. Besides being open, the Nordic economies are small in population, although they differ much with respect to their size, population density and natural resource endowment. The Nordic countries with the exception of Denmark have low population densities. Norway has outstanding resources of oil and hydroelectricity available. Finland and Sweden have access to large forest-resources while Iceland has access to great resources of fish in the Atlantic Ocean.

The project provides some of the required knowledge by analyzing and comparing the existing structure and performance of the Nordic knowledge producing systems. In section 2 there is a detailed description of the theoretical and empirical arguments of why and which framework conditions are important for successful R\&D activities, as well as some indicators of these framework conditions in the Nordic countries. Section 3 presents a description and analysis of the existing efforts and performance of R\&D in both the private and the public sector by looking at the inputs and outputs of the system, respectively. Section 4 discusses in more detail the public sector research in the Nordic countries, including the institutional framework, some recent changes in the public knowledge producing system. In addition, section 4 lists some challenges regarding research priority setting, funding and funding mechanisms, the management of human resources, and the structure of the public knowledge system. Section 5 considers in detail some challenges and changes in the private sector research system in the Nordic countries. This includes public/private partnerships, the access to capital, the role of large multinational companies, and finally the growing importance of the service sector. Section 0 presents results from a Danish case study of the importance of regional framework conditions in Denmark. Section 7 concludes. 


\section{Framework conditions: Importance, measurement and indicators}

The following section provides theoretical arguments for why framework conditions are important for $R \& D$ and innovation activities. In addition, indicators of framework conditions in the Nordic countries will be presented and discussed.

Often, knowledge is a public good, which upon being produced can benefit a wider group than the producer itself. In many cases, knowledge is produced without the researcher or inventor having a specific purpose or application in mind. Many scientific breakthroughs have found a field of application which goes beyond even the most imaginative person's comprehension at the time of the invention. Hence, the rate of return from $\mathrm{R} \& \mathrm{D}$ which an individual person, firm or country perceives is lower than the rate of return which the wider community receives from R\&D. This finds support in empirical studies, where conservative assessments of the private rate of return are 7-14 per cent, and a conservative estima-te of the social return is 30 per cent, c.f. Jones and Williams (1998). Estimates of the social rate of return indicate that this exceeds the private rate of return by 50-100 per cent, c.f. Mohnen (1996).

Therefore it is necessary to consider the relationships between the agents which produce and disseminate knowledge, and other agents which benefit from the production of knowledge. In order to be able to best utilize the production of knowledge at universities and public research institutions, it is necessary to study the interactions between these and the private sector. Furthermore, in order to achieve a high level of knowledge production in the private sector, it is important to study the incentives for private firms to innovate.

Knowledge production and diffusion have changed from being considered as linear processes that involve a limited number of actors, to complex processes involving many disciplines and numerous actors. The first models which were developed of the innovation system described innovation as starting at universities and research institutions, where new knowledge was produced. Then, the knowledge diffused more or less by itself to the surrounding community, where it was transformed into innovation. A main implication of this line of thinking was that government policies should first and foremost aim at increasing research at universities and research institutions. More recent literature recognizes, however, that innovation may arise from a variety of sources without a direct link 
to academic research. Presently a model like the one presented in figure 2.1 is commonly used to describe the innovation system.

Figure 2.1 A model of the innovation system

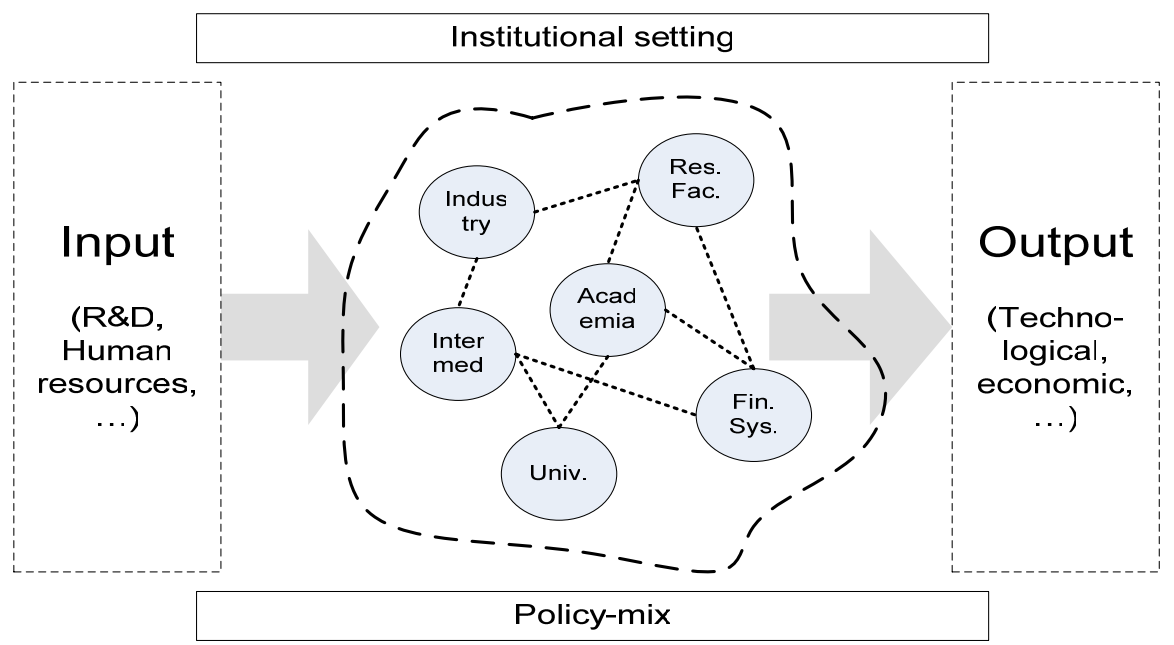

Source: Finnbjörnsson and Verbeek (2005).

Figure 2.1 depicts a complex innovation system: the inputs, the internal functioning of the system, the outputs of the system, and the institutional setting and policy mix which constitute the framework conditions. Inputs into the system consist primarily of the structure of R\&D expenditures as well as several aspects of human resources. The internal functioning is rather complex involving cooperation between and spill-over to and from public research institutions and private enterprises. Output of the system is usually described as some first order outputs like patents and scientific publications. The process from input to output is affected by framework conditions such as public policies and institutional settings.

\subsection{Why are the framework conditions important?}

The reason that framework conditions are important for $R \& D$ can be attributed to two overall aspects:

- A number of central actors within $\mathrm{R} \& \mathrm{D}$ do not have the right incentives to act in a way that benefits the society in the most proper way.

- A number of central actors within R\&D do not have the possibilities to act in a way that benefits the society in the most proper way.

The framework conditions affect both the incentives and the possibilities for conducting R\&D.

In the following, framework conditions are considered to be 
- Intellectual property rights

- Standards and regulation

- Barriers to entrepreneurship

- Access to capital

- Human resources

- Macroeconomic conditions

- Public R\&D

- Public financial support to private R\&D

- Industrial structure and competition

The list is not exhaustive but these are among the more important factors.

\section{Box 2.1 Some definitions}

In this report R\&D will be defined according to the OECD definition as being: "Creative work undertaken on a systematic basis in order to increase the stock of knowledge, including knowledge of man, culture and society, and the use of this knowledge to devise new applications" (OECD (2002)).

Innovation can be considered as a process where knowledge and R\&D are important inputs. A technological product or process innovation (TPP) is defined as: "technologically new products or processes and significant improvements in products and processes. A TPP innovation has been implemented if it has been introduced on the market or used within a production process". According to this definition an innovation does not have to be a completely new product or process, it suffices that it is new to the firm. Hence, an imitation can be an innovation.

$\mathrm{R} \& \mathrm{D}$ activities produce knowledge and this knowledge can in principle diffuse to other actors in the knowledge producing system. Knowledge has a public good nature. The fact that one individual or firm uses knowledge does not exclude other individuals or firms from using that same knowledge. Furthermore, the stock of knowledge is not decreased by firms using that knowledge. However, the fact that a knowledge producing firm has limited possibilities of excluding others from using the same knowledge implies that the firm does not have the appropriate incentive to undertake R\&D and produce knowledge; partly because the firm is not able to obtain the full benefits of its investment. In other words, the social benefits of R\&D investments are higher than the private benefits.

Furthermore, R\&D is characterized by involving considerable economies of scale due to fixed costs of implementing R\&D projects.

Finally undertaking R\&D is connected with a high degree of uncertainty. Partly because it is uncertain whether and when the innovative process will be able to produce the desired innovation, and partly because the resulting market value of the innovation is uncertain. 


\section{Intellectual Property Rights}

Establishing intellectual property rights (IPR) is central in order to give firms, researchers and others an incentive to invest in R\&D.

Intellectual property rights to the results of the $R \& D$ process can be assigned in different ways: One way is patents where a legal body obtains the exclusive property right to the application of an innovation for a certain amount of time. Hence, the legal body obtains a temporary monopoly on its innovation. Other examples of intellectual property rights include copyright and trade mark protection. For an overview of the literature on the optimal design of intellectual property rights see Scotchmer (2004).

Patents and other types of IPR, however, involve a tradeoff between encouraging the firm and researcher to invest in $R \& D$ and on the other hand ensure the diffusion of knowledge.

The incentive to invest in R\&D is strongest if the patent life is long. Both for the legal body obtaining the patent, and for those trying to copy the patented product or process. The longer they have to wait for a release of the innovation, the more they will try to "innovate around it". This may however not be beneficial to society as it might be a social waste to try to imitate or duplicate already existing knowledge. Another drawback of a long patent life is that it limits other firms' and individuals' possibilities of using and building upon already patented knowledge. To this should be added the dead weight loss associated with monopolies.

The most appropriate way of designing intellectual property rights is the one that simultaneously maximizes the advantages and minimizes the disadvantages. This is not necessarily the one that maximizes the amount of R\&D due to the potential efficiency loses discussed above stemming from monopolies and too much duplication in the case of long patent lives.

One possibility for both providing private researchers and firms with incentives to innovate and at the same time giving the wider community access to the knowledge generated is to use so-called "patent buyouts", c.f. Kremer (1998). The idea is that the state purchases the patent rights from successful innovators and makes the patent public, so that anyone can exploit the new knowledge. The correct price of the patent can be found by selling the patent in an auction, where the state buys the patent at the price found at the auction. 
Figure 2.2 Patent rights in the Nordic countries

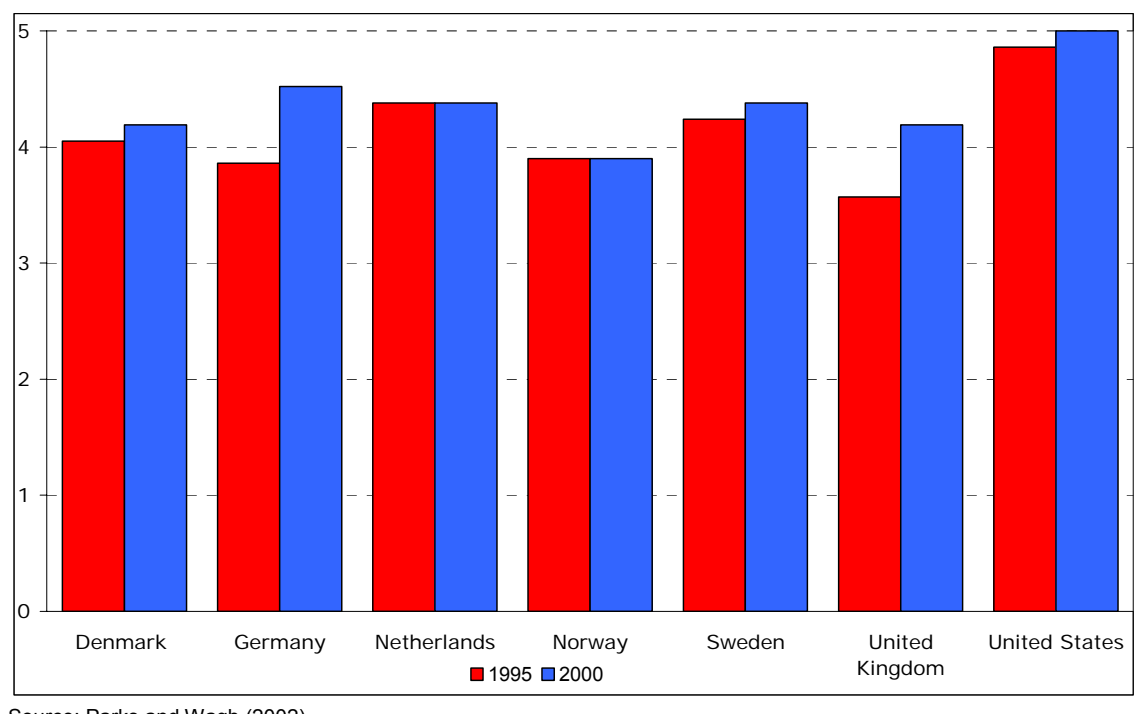

Source: Parks and Wagh (2002)

The OECD has developed an internationally comparable indicator of patent rights, based on among other things the duration and extent of patent rights in different countries. The indicator is measured on a scale from 0 to 5 where each component, e.g. duration of patents, is assigned a score. Figure 2.2 illustrates that the Nordic countries have marginally weaker patent rights than Germany and the Netherlands and much weaker than the United States.

OECD (2005) is the most recent study to empirically investigate the effect of patent rights on $R \& D$ activities. The data set is rather comprehensive and covers 19 countries from 1982-2001. They do not find any statistically significant effect of patent rights on R\&D activities.

\section{Standards and Regulations}

Standards and regulations are often thought of as the solution to market imperfections, such as externalities.

An important policy area affecting the incentives for $R \& D$ is labor market policy. Regulations on the labor market may be detrimental to R\&D if they dampen the incentive to find and attract highly specialized and qualified workers. An example might be immigration rules which make it hard for firms to attract and retain highly specialized foreign labor. On the other hand, labor market regulations and policy can help create the right incentives by for instance promoting continued learning and by up-grading of the labor force's skills. 
Figure 2.3 Product market regulation in the Nordic countries, index

Source: Conway, Janod, and Nicoletti (2005).

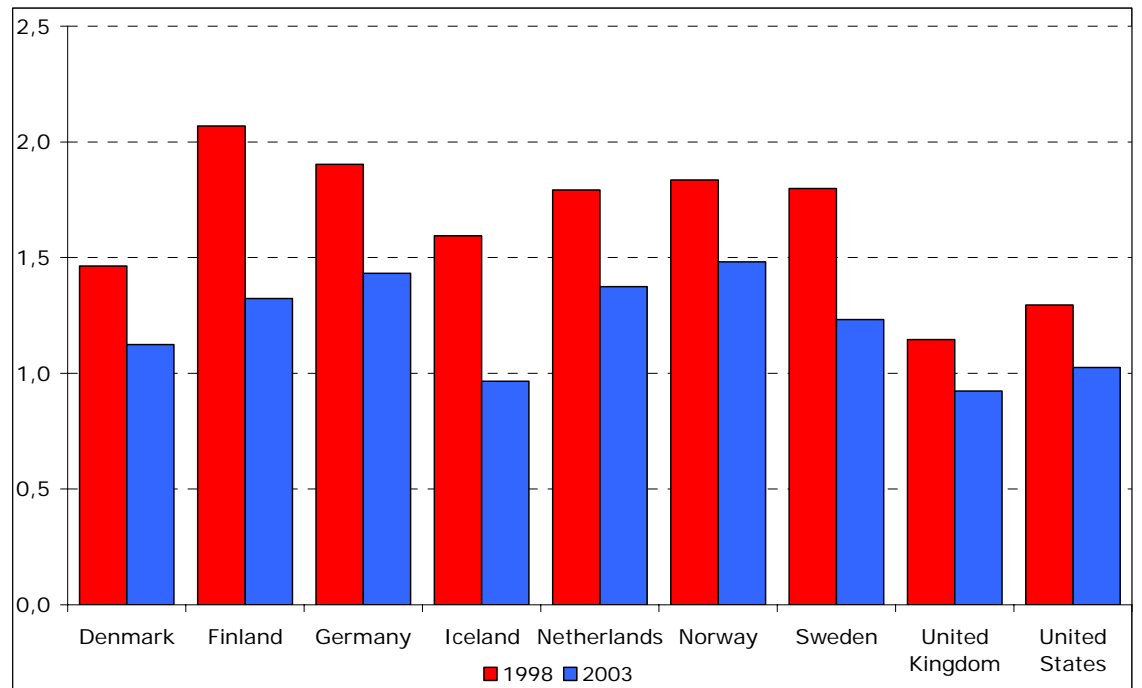

Furthermore, incorrectly designed government regulations may hamper competition, possibly to the detriment of innovation, as described elsewhere in this report.

OECD has developed an indicator of public regulation of the product market. The indicator is calculated on the basis of a point system, where a country's different types of regulation on the product market are given points from 0 to 6 , where 6 is the most restrictive. The drawback of this indicator is that it entails a certain subjective element and it is without a clear theoretical foundation.

Figure 2.3 shows that public regulations on the product market have decreased from 1998 to 2003 in the countries listed. Norway has the highest amount of regulation among the Nordic countries in 2003 and only Iceland has an index level comparable to the USA. On the other hand, the level for the rest of the Nordic countries is low ranging between 1,1 and 1,5 on a scale from 0 to 6 .

\section{Barriers to Entrepreneurship}

With the proliferation of modern growth theory, it has become apparent that entrepreneurship is essential for innovations. The older literature focused more narrowly on the importance of scale economies, but in more recent theories the role of entrepreneurship for innovation has been stressed. Barriers to entrepreneurship may thus hamper innovation.

The barriers can take many forms. Foremost is the lack of risk willing capital and access to a well functioning credit market in general (see the next section). Another impediment may be lack of access to relevant consultancy services since many entrepreneurs do not necessarily possess the necessary administrative and management skills. 
Yet another obstacle may be considerable "red tape" in both establishing and closing a firm. If it is connected with a substantial administrative burden to establish a firm, many entrepreneurs may simply give up before they ever get started. Barriers to closing a firm, such as red tape involved in going through bankruptcy proceedings, inhibit an appropriate reallocation of resources. However, often barriers to closing a firm reflect an intention to protect the creditors and thus maintain a well functioning credit market. Hence, it is a delicate matter of on the one hand protecting the investor's interests, and on the other to ease the reallocation of resources.

OECD has developed a crude index to measure the barriers to entrepreneurship. This index covers among other things bureaucracy in connection with establishing a firm, the costs of establishing a new firm, administrative burdens in the daily business operations, problems of obtaining external finance, and taxes. The different barriers are attached a value from 0 to 6 , where 6 is the most restrictive. All the different indices are aggregated into a total index that is shown in figure 2.4 .

Figure 2.4 Barriers to entreprenuership, index

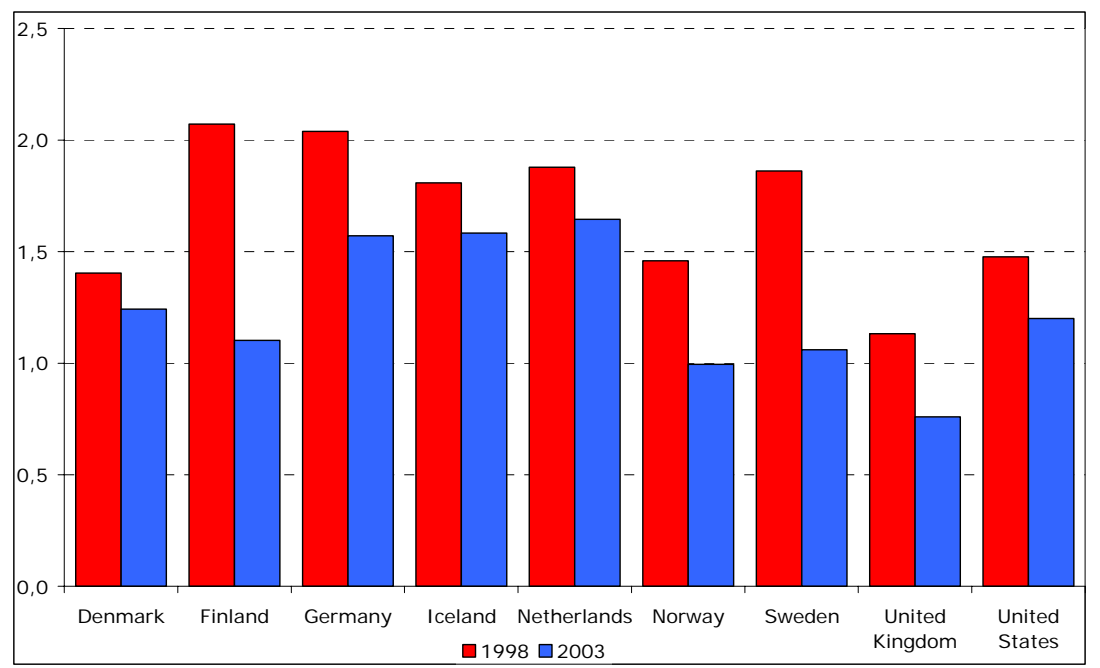

Source: Conway, P., V. Janod, and G. Nicoletti (2005), "Product Market Regulation in OECD Countries, 1998 to 2003", OECD Economics Department Working Paper, No 419

Based on this index, the barriers to entrepreneurship are for all Nordic countries, except Iceland, at a level and comparable to that of the USA. In Finland and Sweden, the barriers have been reduced significantly from 1998 to 2003, placing them slightly below Denmark and slightly above Norway.

\section{Access to Capital}

The purpose of R\&D is to produce new knowledge. However, the production of new knowledge is subject to considerable uncertainty because there does not exists a direct relationship between $R \& D$ expenditures as an input to the process and the output in terms of new knowledge and innovations. R\&D is considerably more uncertain than activities that 
concern known products and processes. This is the case both for the actual production of new knowledge, and to the market value of an eventual innovation. As a consequence, it might be difficult to obtain external financing of $\mathrm{R} \& \mathrm{D}$ activities.

For the entrepreneur a similar problem arises. Credit institutions may be reluctant to provide capital to entrepreneurs because the success or failure of the entrepreneur is not controllable by the lender, but partly by the entrepreneur himself. This results in a classical principal-agent problem.

In both cases - R\&D and entrepreneurs - a possible improvement could be to set up markets for venture capital. Venture capital is a mode of financing where the investor provides both capital and expertise to the lender. Particularly in relation to entrepreneurship, this way of financing the activities might prove helpful, since the venture capital investor gains some control in relation to running the business, and hence alleviate some of the problems of asymmetric information between the lender and the borrower. Furthermore, the expertise of the investor can be of great importance to the entrepreneur's possible success.

Table 2.1 generally shows no clear trend in the use of venture capital in the Nordic countries. On the contrary there seems to be a great deal of variation from year to year. However, the use of venture capital for high technology projects has increased in Denmark, and the share of early stage venture capital has increased as well. In a European context, all Nordic countries perform better than average, with the exception of Norway.

Table 2.1 Access to venture capital in the Nordic countries

\begin{tabular}{|c|c|c|c|c|c|c|c|c|}
\hline & \multicolumn{4}{|c|}{$\begin{array}{l}\text { Share of high-tech venture capital } \\
\text { investment in venture capital }\end{array}$} & \multicolumn{4}{|c|}{ Share of early stage venture capital in GDP } \\
\hline & 2000 & 2001 & 2002 & 2003 & 2000 & 2001 & 2002 & 2003 \\
\hline & \multicolumn{8}{|c|}{ 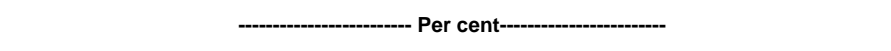 } \\
\hline Denmark & 30.3 & 32.2 & 63.4 & 69.8 & 0.02 & 0.05 & 0.08 & 0.06 \\
\hline Finland & 50.6 & 61.1 & 54.0 & 49.0 & 0.08 & 0.10 & 0.09 & 0.07 \\
\hline France & 51.7 & 52.4 & 60.2 & 57.4 & 0.06 & 0.06 & 0.04 & 0.03 \\
\hline Germany & 45.7 & 43.2 & 60.8 & 63.4 & 0.07 & 0.07 & 0.04 & 0.02 \\
\hline Iceland & 33.0 & 53.3 & 35.8 & . & 0.29 & 0.24 & 0.05 & . \\
\hline Netherlands & 45.5 & 42.2 & 39.2 & 34.0 & 0.10 & 0.07 & 0.04 & 0.03 \\
\hline Norway & 33.0 & 41.8 & 36.8 & 32.8 & 0.04 & 0.05 & 0.04 & 0.03 \\
\hline Sweden & 46.5 & 47.6 & 52.9 & 48.1 & 0.10 & 0.09 & 0.10 & 0.08 \\
\hline United States & . & . & . & . & 0.23 & 0.20 & 0.07 & . \\
\hline
\end{tabular}

Note: Numerator: High-tech venture capital includes the following sectors: computer related fields, electronics, biotechnology, medical/health, industrial automation, and financial services.

Denominator: Venture capital is defined as the sum of early stage capital (seed and start-up) plus expansion capital. Source: Trendchart Scoreboard 2004

Appendix A contains a survey of recent Nordic venture capital initiatives. The Nordic countries have exerted great efforts in recent years to set up well functioning markets for venture capital. A major challenge is to find 
an efficient financing mechanism that balances the need for seed capital to SME's and entrepreneurs and on the other hand the need for mechanisms to end the project if the prospects are bad. This is so, either because there is no potential for the end product or because the research drifts into either "blue-sky research" or into outsourced corporate R\&D. Possible solutions require a strict monitoring system and well specified clauses for risk sharing and termination conditions.

For more established firms venture capital may not be as important as a well functioning credit market and banking sector. Although some of the Nordic countries have witnessed mergers in the banking sector, the banks are still small on an international scale. This should simply be noted as a fact more than a challenge since by the very size of the Nordic countries it is hard to imagine bigger national or Nordic banks.

\section{Human resources}

In the production of knowledge, human resources is a necessary input, and access to highly qualified labour is a prerequisite for private firms to engage in R\&D. A large supply of highly qualified and specialized labour reduces the costs of the firm in its search for a match between its needs and the available supply. Furthermore, it increases the probability of finding the right match.

Figure 2.5 Share of 20-29 year old who study science and engineering

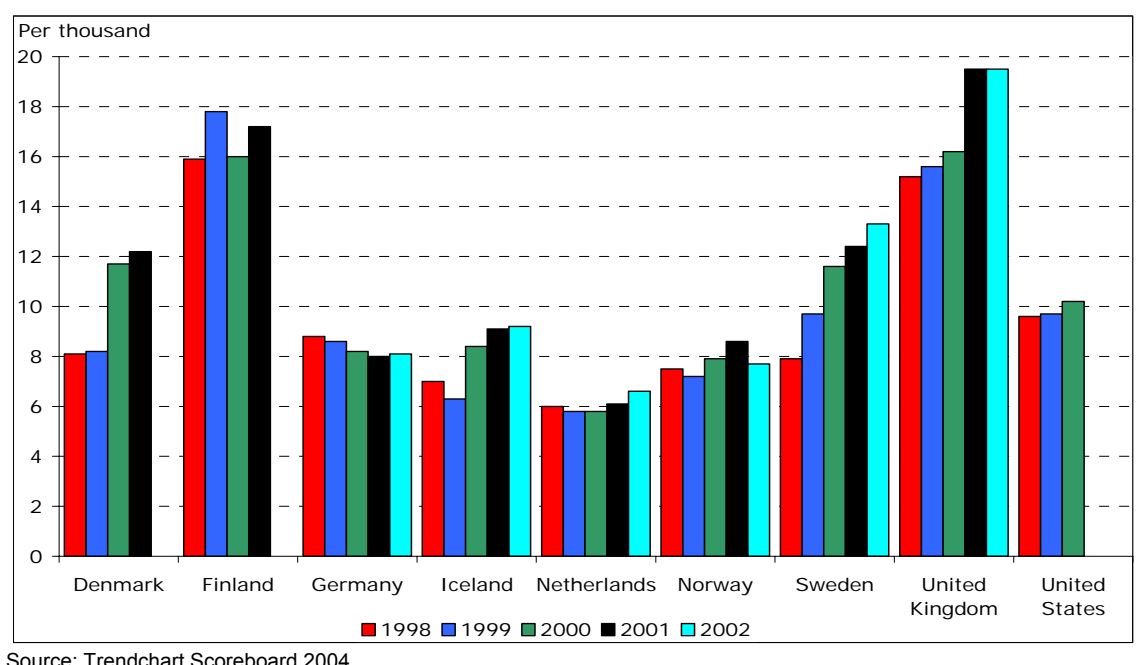

At the same time, it is important that the firm has highly qualified labour in order to absorb knowledge and hence engage in R\&D activities. Cohen and Levinthal (1989) discuss "the two faces of R\&D". That is, R\&D has a positive effect on the firm's value added, but also an indirect effect since doing R\&D increases the firm's ability to absorb knowledge from other places. This requires highly qualified human resources among other elements. 
There are several measures available for the amount and quality of human resources. The share of 25-64 year old with tertiary education is relatively high in the Nordic countries in an international comparison, with the possible exception of Iceland. Recent years has seen an increase in the share of population with tertiary education in the Nordic countries, with the possible exceptions of Sweden and Norway. The share of 20-29 year old who study science and engineering has also increased in the Nordic countries in recent years. Concerning the position of the Nordic countries in an international comparison, Finland belongs to the international top, whereas Norway is placed fairly low in such a ranking.

\section{Macroeconomic conditions}

Enhanced macroeconomic stability allows firms to plan more effectively for the future. Stable and possibly strong output growth is also beneficial to firms planning to introduce new products or processes. Furthermore a low and predictable real interest rate generally promotes investments and $R \& D$, although it is known from the real options approach to investments that the timing of investments and hence $\mathrm{R} \& \mathrm{D}$, may be affected in a nonmonotone way by uncertainty (for an overview of this literature see Dixit and Pindyck (1994)). A positive but low inflation rate is also conducive to creating a stable and predictable macroeconomic climate.

In a very recent study on the macroeconomic conditions by OECD (2005), evidence is found that macroeconomic factors contribute significantly to understanding the evolution of business R\&D expenditure. Strong output growth and low inflation rates both have a significant positive effect on the growth rate of $R \& D$. The same is true for factors that help to lower the real interest rate.

\section{Public R\&D and Public R\&D policies}

\section{Public R\&D}

Public R\&D typically takes place in universities or in publicly financed research institutes, but it can also take place in the private sector. It is much debated whether public R\&D and public support to R\&D enhances private R\&D or crowds out private R\&D. Goolsbee (1998) found that US R\&D spending in the period 1968 to 1994 had a large and significant effect on the wages of scientific personnel, but no statistically significant effect on the hours worked. Since then, the literature has exerted great effort in establishing whether government R\&D policy increases the amount of private sector R\&D.

There is a tendency for empirical research to find that public support to $R \& D$ has a positive impact on the overall level of $R \& D$ (see below). However, the studies tend to measure private $R \& D$ expenditure, not $R \& D$ output. So, strictly speaking, it may be that the observed effect on private 
sector $R \& D$ to a large degree is a reflection of increased public $R \& D$ expenditure leading to higher wages for R\&D personnel. When this is said, it is also a general finding that there is a statistically significant relationship between R\&D spending and private firms' value added. Thus, it can be expected that the increase in R\&D input caused by public R\&D expenditure leads to some R\&D output as well.

\section{Public Support to R\&D}

If private benefits from doing $R \& D$ are lower than social benefits, public support to private R\&D can be justified. Public support thus becomes an important factor in the common innovation infrastructure. The support can take different forms. In the following, three types will be investigated: subsidies to $R \& D$, tax relief from doing $R \& D$, and public supply of $R \& D$ projects.

Figure 2.6 Expenditure on R\&D per cent of GDP

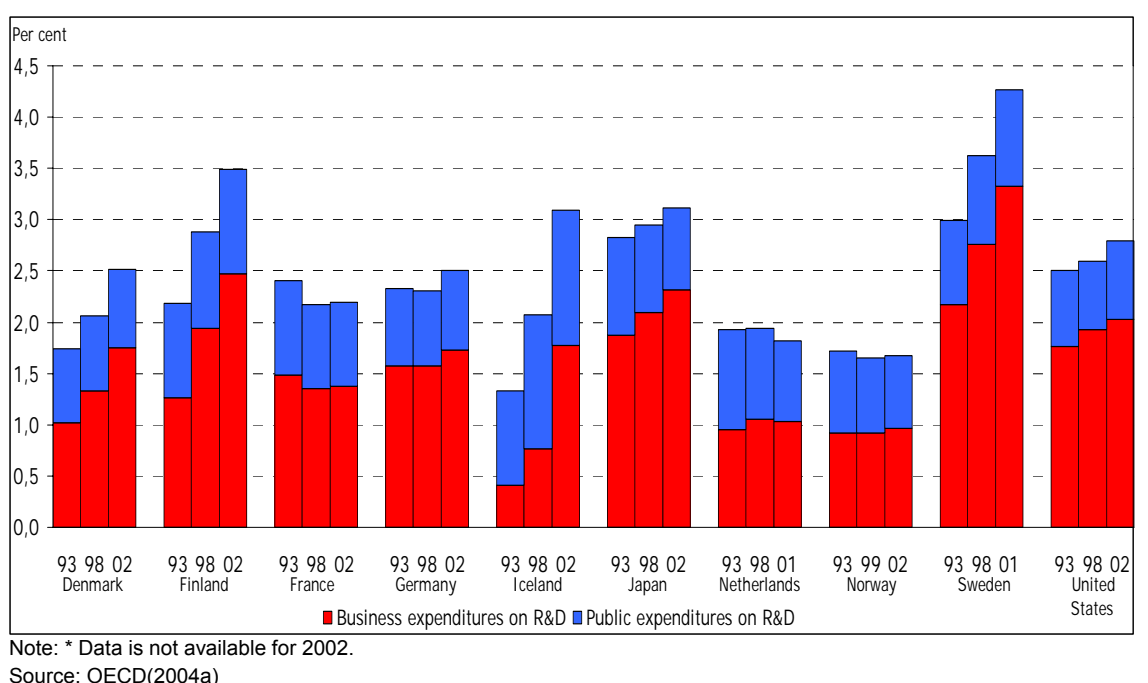

Subsidies to Private $R \& D$

Subsidies are typically given to successful applicants in some sort of competition where an expert committee evaluates the applicants' project proposals. Subsidies are given prior to the launching of the R\&D project and are not dependent upon success of the project.

A disadvantage of subsidies is that the state may support R\&D projects that would have been carried out even without the co-financing. This can happen because the authorities have less infor-mation on the $R \& D$ project than the firm which is carrying it out.

A further disadvantage that has to be taken into account is the costs of raising tax revenue to finance the subsidy.

Empirical studies by Czarnitski and Licht (2005), by Guellec and Van Pottelsberghe (2003) and Sørensen et al (2003) find, using different methods and data, that there seems to be a positive effect from public subsidies to $R \& D$ on private $R \& D$ expenditures. 
Tax reliefs for doing $R \& D$

General tax reliefs differ from subsidies by the fact that firms can determine which $R \& D$ projects receive support. In the subsidy model, the state picks the projects. The advantages of the tax relief model relative to the subsidy model are that time is not spend by highly qualified government employees in evaluating the applications, and that it involves a lower risk of crowding out private R\&D since it lowers the private costs of undertaking $R \& D$.

However, just as in the case of subsidies there still exists a risk that the state supports projects that would have been carried out even without the tax relief, and the costs of raising a tax revenue to finance the tax relief also has to be taken into account. It also creates an incentive for the firm to classify non-R\&D activities as R\&D activities in order to obtain higher tax relief.

OECD (2005), Bloom et al (2002) and Guellec and Van Pottelsberghe (2003) all find that tax reductions have a significant positive impact on private R\&D.

Among the Nordic countries Denmark and Norway are the countries with the most lucrative tax treatment of R\&D expenses. In the other Nordic countries the index does not reveal any fiscal incentives for firms to undertake $R \& D$ activities.

\section{Public Supply of R\&D projects}

Public supply of R\&D projects can be done in at least two ways: Innovation competitions and R\&D by contract. In both cases the idea is that the state acquires the property right to an innovation and releases the innovation such that it becomes publicly available. In this way the problem of a temporary monopoly can be avoided.

In the innovation competition the state poses an innovation task and rewards the first one to solve it. In research by contract the state engages in a contractual relationship with a limited number of firms and pays them for providing the innovation.

The advantage of innovation competitions is that it is open to all, and self-selection is supposed to happen such that only the most able firms participate. The major disadvantage is that potentially many firms try to make exactly the same innovation. Hence, there is much of R\&D duplication which from a social point of view might be a waste.

The advantage of research by contract is that only a limited number of firms are involved, making it possible to have a concurrent dialogue with them, adjust the goals as new knowledge is obtained, and avoid duplication of efforts. The disadvantage is the well known principal-agent problems that arise in contractual cooperation. 
Figure 2.7 Tax subsidy to R\&D per \$ spent on R\&D

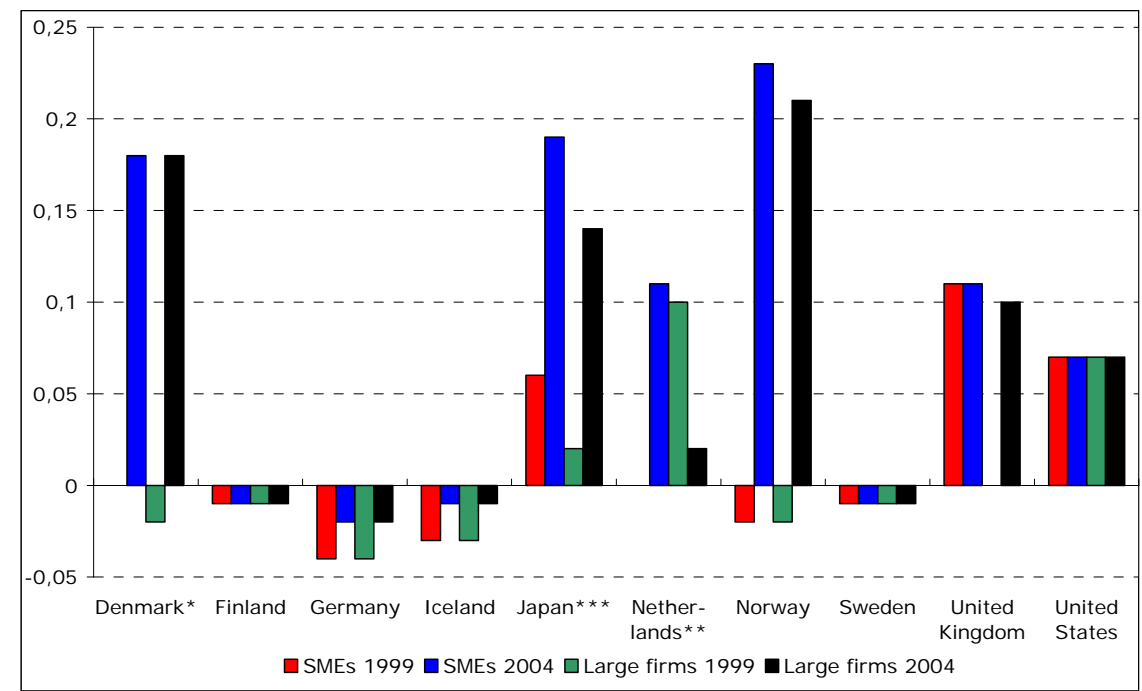

Note: Tax subsidies are calculated as 1 minus the B-index

The B-index for large firms with a R\&D-to-sales ratio above $10 \%$ is 0.831 . The B-index for research conducted in collaboration with universities is 0.782 .

* SMEs are not available 1999. "Large firms 1999" is 1998 instead

** SMEs 1999 are not available

*** The 2004 B-index for large firms in Japan applies to firms with a ratio of R\&D to sales of less than $10 \%$. Source: OECD(2004a)

\section{Industrial Structure and Competition}

There are several characteristics of the industrial structure, including product market competition and competition within the R\&D industries, which play major roles for obtaining the most knowledge creation and innovation of the $R \& D$ process.

In the following different theoretical and empirical results regarding these matters will be considered. It has not been possible to construct a set of common indicators which can illustrate these framework conditions for the Nordic countries, instead the industry structure and level of competition in the countries are described in small country case-studies in the following.

Industry specialization, diversity and maturity

It is common to distinguish between two different kinds of externalities of knowledge transfer within the R\&D literature cf. Glaeser et al (1992).

- Marshall-Arrow-Romer (MAR) externalities

- Jacobs externalities

MAR externalities (Marshall (1890), Arrow (1962), and Romer (1986)) arise between firms within the same industry. The argument is that knowledge transfer happens most effectively between similar firms. The reason is that mobility of workers between firms, informal contacts, and imitation are easier between similar firms. 
Jacobs externalities (Jacobs (1969)) arise between firms in different industries. The causes are almost the same as for MAR externalities but the effect is the opposite. Diversity is a source of inspiration, and hence the more different firms that are located within the vicinity of a particular firm, the more fruitful will this firm's innovation process be.

More recently Duranton and Puga (2001) have formed a synthesis of MAR and Jacobs externalities in the product life cycle: For new technologies, knowledge externalities are greatest when firms are located in industry-wise diversified regions, while the opposite is true for mature technologies. Here, the externalities are greatest when firms are located in industry-wise specialized regions. The arguments are the following: For new technologies, firms have yet to find best practice, and therefore it pays off to be close to firms from other industries as a source of inspiration. For mature technologies, it is of higher importance to be among similar firms, in order to be able to decode progress from these.

In any case, since knowledge to a certain extent is limited geographically mobile, the industrial structure is important for the extent of knowledge externalities and hence the success of R\&D. Knowledge may not be very mobile due to for instance low mobility of workers. There is a plethora of studies which indicate that this is true, even in a small country like Denmark, cf. Andersen (2000). Another reason could be that knowledge is embedded in products and processes and firms operate in geographically limited areas.

Duranton and Puga (2001) present empirical evidence that support the product life cycle theory. There tends to be a reallocation of firms such that industry-wise diversified regions host many newly started enterprises, and that these firms over time tend to move to specialized regions. Other studies like Audretsch and Feldman (1996), Henderson et al (1995), and Glaeser (1992) all find that diversity is conducive to innovation. There is, however, no consensus on whether or not specialization is good or bad for innovation.

Therefore, there are a number of reasons to believe that regional specialization and diversity combined with technological maturity play a role for the innovative activity in an industry.

\section{Firm size and economies of scale}

It is well established in the literature that there are economies of scale within R\&D, see e.g. Geroski (1995). These exist because, e.g. investments in apparatus, hiring of highly skilled workers, and researching of existing knowledge require a certain minimum level for $R \& D$ to be profitable. In many cases the minimum efficient level of $R \& D$ is considerable.

Eeckhout and Jovanovic (2001) find that small firms obtain their knowledge by free-riding on larger firms' R\&D. Therefore, the small firms have only weak incentives to engage in $R \& D$ themselves. Cohen 
(1995) summarizes the empirical findings until the mid 1990's of the relation between firm size and R\&D thus: There seems to be consensus that large firms are engaged in more $R \& D$ activities than small firms.

Hence, in an industrial structure with many small enterprises, the incentive to engage in $R \& D$ may be smaller.

\section{Competition in the product market}

The importance of product market competition for R\&D has long been debated in the economics literature. There are opposing views on the significance of competition for R\&D. If competition is strong in the product market it implies that profits are low, and since R\&D requires extensive investments, it means that $R \& D$ activities will be low in situations of low profits. This argument has most prominently been put forward by Schumpeter, the founding father of modern growth theory.

As a counter argument Jacobs (1969) and Porter (1990) argue that increased competition enhances $R \& D$ activities, because strong product market competition has the implication that only those firms innovating products and processes have a chance of surviving in the longer run. Monopolies, on the other hand, are more focused on harvesting the monopoly rent and prevent entry into the market.

As a synthesis of the two opposing views, it could be argued that when competition is low, increased competition strengthens management incentives to innovate, because there is an increased risk that if they do not innovate, they will lose their job and the perquisites associated with it. On the other hand, when competition is fierce, profit margins are so tight that there is no room for rewarding an extra effort by management. In this case an increase in competition further diminishes the ability of the owners of the firm to reward the management for innovating. This synthesis was developed by Schmidt (1997). Aghion et al (2002) is another recent paper finding that there is a non-monotonic relationship between product market competition and innovation. The theory of a humpshaped relationship gains support in the most recent empirical investigation by Aghion et al (2002) ${ }^{1}$.

There is thus reason to believe that there does not exist a monotone relationship between product market competition and R\&D activities and hence innovations. In fact, it might exhibit an inverted U-shape such that increased product market competition for low initial levels of competition increases R\&D activities, and reduced competition for initial high levels of competition increases R\&D activities.

One of the cornerstones in strong product market competition is free entry and exit of firms. And this may also be a source of increased inno-

\footnotetext{
${ }^{1}$ In the path-breaking paper by Nickell (1996), which was the first in an empirical study to apply profit-based indicators of competition, and the first to seriously study the relation between competition and innovation, he finds that increased competition tends to increase total factor productivity (and possibly innovation).
} 
vative activities through the so-called "creative destruction": New firms enter the market and introduce new products and processes, and thereby drive out existing firms with obsolete and old-fashioned technology. An example of this is found in Aghion and Howitt (1998).

These results pose a challenge to the conduct of competition policy. It has to balance the short run aim of low prices and hence strong product market competition against the long run aim that firms are allowed some profit in order to provide incentives for R\&D activities. Thus, there is a trade-off between static and dynamic efficiency.

\section{Competition in the $R \& D$ industry}

Whereas the significance of product market competition on R\&D activities may be inconclusive, at least theoretically, there are strong arguments supporting the view that competition within the R\&D industry has a positive impact on the quantity and quality of R\&D. See e.g. Aghion and Howitt (1998).

\section{Technological level}

Eeckhout and Jovanovic (2001) study the consequences of the composition of firm size and technological leadership on the incentive to undertake R\&D. They find that firms far from the technological frontier have a low incentive to undertake R\&D. Instead, they free ride on the other firms.

Based on this, but not directly a consequence of their model, it can be argued that if low-tech firms free-ride on high-tech firms' R\&D activities, it constitutes a problem for an economy's total R\&D effort if the industrial structure is such that it consists mainly of low-tech firms.

OECD (2005) documents that in countries with high R\&D intensities, a high share of the business R\&D and a significant part of the economic output is found in high-tech industries. In Finland, Germany, Japan, Switzerland and USA, high-tech industries account for $75 \%$ or more of all business $R \& D$ expenditures. Based on a literature survey, Bartelsman and Doms (2000) conclude that firms that belong to the high-tech category today have a substantial probability of also being high-tech tomorrow.

The Nordic countries share many common features but important differences exist as well.

Norway is probably the most industrially specialized economy of the Nordic countries, but the specialization or industrial agglomeration lies to a large extent in mature industries, which according to the Duranton and Puga (2001) argument should be an advantage. Due to lack of internationally comparable data it is difficult to draw conclusions about whether the level of industrial agglomeration is conducive to $R \& D$ and innovation. 
It is also difficult to evaluate whether the level of product market competition is conducive to $R \& D$ and innovation in the Nordic countries. Iceland does appear to have problems in fostering competition due to its small population, which leaves room only for few firms in industries with important economies of scale, e.g. network industries such as telecommunications.

The bulk of firms are very small indeed. There exist only few large firms and few large multinational firms. Sweden and Finland each have one very big multinational firm within the high-technology category (Ericsson and Nokia, respectively). Neither of the other countries has a similar industry driver in high-tech manufacturing. Norway has, in contrast to the other Nordic countries, an economy with a strong specialization in the use and extraction of natural resources and industries related to that. The mass of small firms should ceteris paribus be expected to yield a suboptimally low level of R\&D and innovation.

The technological level in the Nordic countries does not stand out in an international comparison, though both Iceland and Norway would appear to have economies founded on low-technology industries. The low technological levels in Norway and Iceland may pose a problem for private sector incentives and possibilities to undertake $R \& D$. In the rest of the Nordic countries it is difficult to say whether the general technological level per se stimulates or hampers R\&D and innovation.

In the industrial structures of the Nordic countries are described in further detail.

\section{Summary of framework conditions}

World Economic Forum publishes each year a ranking of the World's countries according to competitiveness. This is done by the so-called Global Competitiveness Index (GCI). The GCI is composed of three "pillars," all of which are widely accepted as being critical to economic growth: the quality of the macroeconomic environment, the state of a country's public institutions, and, given the increasing importance of technology in the development process, a country's technological readiness. Using a combination of publicly available hard data, and information provided in the Forum's Executive Opinion Survey-which provides more textured qualitative information on difficult-to-measure conceptsthese three pillars are brought together in the three indexes of the GCI: the macroeconomic environment index, the public institutions index, and the technology index.

Even though this index has shortcomings and may not be very precise as an indicator of competitiveness, it is still noticeable that among the first six countries in this ranking are four Nordic countries. And Iceland is placed as number 10. Finland is ranked number one. 
At least at a first glance it appears that the general framework conditions conducive for growth in the Nordic countries are not found much better elsewhere in the world except in the USA.

Table 2.2 Global competitiveness index

\begin{tabular}{lccc}
\hline Country & GCI 2004 rank & GCI 2004 score & GCI 2003 rank \\
\hline Finland & 1 & 5.95 & 1 \\
United States & 2 & 5.82 & 2 \\
Sweden & 3 & 5.72 & 3 \\
Taiwan & 4 & 5.69 & 5 \\
Denmark & 5 & 5.66 & 4 \\
Norway & 6 & 5.56 & 9 \\
Singapore & 7 & 5.56 & 6 \\
Switzerland & 8 & 5.49 & 7 \\
Japan & 9 & 5.48 & 11 \\
Iceland & 10 & 5.44 & 8 \\
United Kingdom & 11 & 5.30 & 15 \\
Netherlands & 12 & 5.30 & 12 \\
Germany & 13 & 5.28 & 13 \\
Australia & 14 & 5.25 & 16 \\
Canada & 15 & 5.23 &. \\
United Arab Emir- & 16 & 5.21 & 17 \\
ates & & & 14 \\
Austria & 17 & 5.20 & 20 \\
New Zealand & 18 & 5.18 & 22 \\
Israel & 19 & 5.09 & \\
Estonia & 20 & 5.08 & \\
\hline
\end{tabular}

Source: World Economic Forum, Global Competitiveness Report, 2004-05

To summarize this section on framework conditions:

- There is no clear theoretical or empirical prediction of whether strong patent rights are conducive to $R \& D$ and innovation or not. The Nordic countries belong to a "middle-group" in an international comparison on this indicator.

- Standards and regulations and barriers to entrepreneurship have theoretically and empirically documented negative effects on R\&D. The Nordic countries, as a whole, belong to an international "middlegroup" measured by indicators of these framework conditions.

- Access to capital has theoretically and empirically documented positive effects on R\&D. The weight of the evidence seems to suggest that Norway has problems with access to funds for R\&D investment. Measured by the use of venture capital at the early stage in projects, Denmark, Finland and Sweden do well in international comparisons, though it is difficult to draw conclusions as to whether there is "easy" access to R\&D funding for private firms in these countries.

- Access to human resources is a very important framework conditions for several reasons. In general the Nordic countries have ample supply of highly educated labor, with the possible exception of Iceland, and though Norway may perform poorly with respect to access to labor with educations in science and engineering. 
- Public sector support to R\&D has theoretically and empirically documented positive effects on private sector R\&D. The Nordic countries differ much with respect to the availability of tax relief for R\&D expenditure, and the share of GDP spent by the public sector on R\&D also differs much between the Nordic countries.

- Theoretically, industrial agglomeration can have positive or negative effects on innovation, but the weight of the empirical evidence suggests that industrial agglomeration is negatively associated with innovation. Norway is the only Nordic country, which could be dubbed as having high levels of agglomeration in natural resource related industries.

- Theoretically and empirically, very low or very high levels of product market competition are associated with relatively low levels of innovation. Only Iceland appears to have difficulty fostering product market competition.

- The presence of many large firms should theoretically and empirically be expected to result in high levels of R\&D. Only Sweden and Finland have a few very large multinational firms, and all countries have many small firms.

- A high technological level should theoretically be conducive to R\&D, but there has been found no statistically evidence of this relationship. Norway and Iceland appear to be low-technology economies in an international comparison. The other Nordic countries belong to an international middle group. 



\section{Measurement and Main Indicators of R\&D and Innovation Activities in the Nordic Countries}

Having looked at the importance and some indicators of framework conditions, the following section will look carefully into the inputs to the knowledge producing system and the output hereof. The two main inputs are expenditures to $\mathrm{R} \& \mathrm{D}$, both private and public, and the available human resources. Output is not easy to measure but the most commonly used indicators are of business $R \& D$ output are the number of patents and innovations, whereas the number of published articles in scientific journals is a commonly used indicator of public R\&D output. There exist however, some measurement problems which will be described in Appendix C.

\subsection{Inputs into the Knowledge Producing System in the Nordic Countries}

\section{$R \& D$ Expenditures}

On the input side, expenditures to $R \& D$ is a very common measure, though it is a broad measure it forms the basis of policy recommendations of for instance The European Union in their Barcelona target.

Table 3.1 Total R\&D expenditures as pct of GDP

\begin{tabular}{llllllll}
\hline & 1985 & 1989 & 1993 & 1997 & 2001 & 2002 & 2003 \\
& & & & & & \\
& & & & & & \\
& & & & & & \\
Denmark & 1.21 & 1.51 & 1.74 & 1.94 & 2.41 & 2.53 &. \\
Finland & 1.56 & 1.81 & 2.16 & 2.71 & 3.41 & 3.44 & 3.49 \\
France & 2.22 & 2.29 & 2.4 & 2.22 & 2.23 & 2.26 & 2.19 \\
Germany & 2.68 & 2.79 & 2.33 & 2.29 & 2.51 & 2.53 & 2.55 \\
Japan & 2.75 & 2.89 & 2.83 & 2.84 & 3.07 & 3.12 & 3.15 \\
Netherlands & 1.99 & 2.04 & 1.93 & 2.04 & 1.88 & 1.80 &. \\
Norway & 1.48 & 1.68 & 1.72 & 1.64 & 1.60 & 1.67 & 1.75 \\
Sweden & 2.78 & 2.80 & 3.17 & 3.54 & 4.27 &. & 3.98 \\
United States & 2.75 & 2.61 & 2.52 & 2.58 & 2.73 & 2.66 & 2.60 \\
Iceland & 0.74 & 1.02 & 1.35 & 1.88 & 3.06 & 3.09 & 3.04 \\
\hline
\end{tabular}

Source: OECD Database, Science and Technology. 
Figure 3.1 Composition between business and public R\&D as pct of GDP

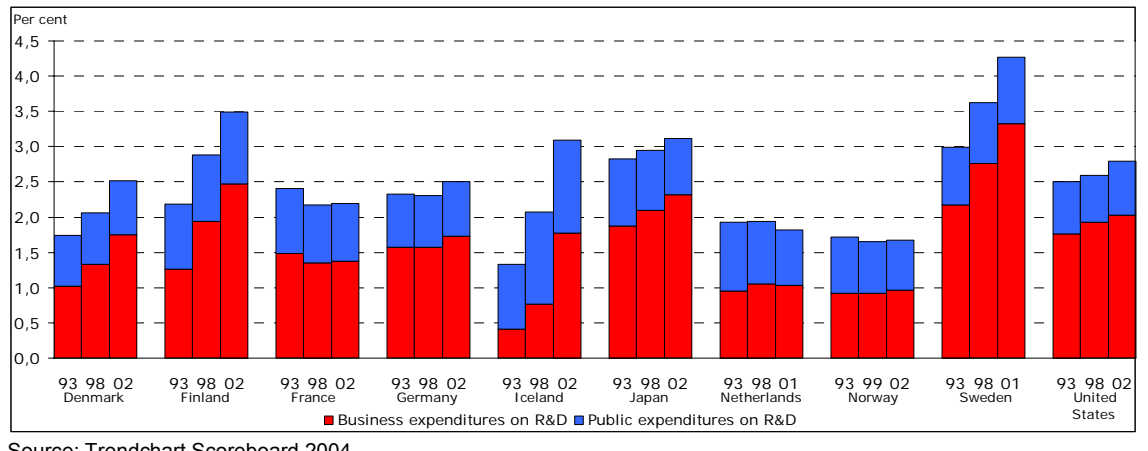

Table 3.1 reveals that total gross $R \& D$ expenditures have been growing over the last two decades for all Nordic countries with Norway as the only exception. The growth has mostly taken place in the 1990's. In particular, and most rapidly, in Finland and Iceland, although Denmark has also experienced more growth in R\&D expenditures in the 1990's than in the 1980's. Table 3.1 also shows that there are quite substantial differences in the R\&D expenditures between the Nordic countries. Sweden and Finland spend large amounts on R\&D and are way beyond the target set by the EU of spending 3 per cent of GDP on R\&D in year 2010. Also in international comparisons the Nordic countries except Norway, perform well on this indicator. They are at or above the level of USA, and well above the EU-25 average on R\&D expenditures that in 2003 were 1.85 per cent of GDP.

Figure 3.1 shows that what have been driving the increase in $R \& D$ expenditures in the Nordic countries are mostly business R\&D expenditures, though public R\&D spending has been increased in most countries as well. Finland has increased the business share of R\&D expenditures by 1.21 percentage points between 1993 and 2002 and Iceland by 1.36. This is very impressive on an international scale. In the same period EU-15 increased the business share by 0.08 percentage points.

But there are big differences in the composition between the countries. In Sweden the business sector has the highest share of total R\&D expenditures of approximately 80 per cent of total expenditures in 2001 followed by Finland and Denmark by 70 per cent in 2002. Iceland and Norway have turned their compositions from having a larger share of public than business expenditures. The share of public expenditures in 2002 was 43 per cent in both countries which is relatively high also in an international comparison. 
Table 3.2 Government appropriations for R\&D, per cent

\begin{tabular}{lrrrr}
\hline & \multicolumn{2}{c}{ Share of total budget } & & \multicolumn{2}{c}{ Share of GDP } \\
& $\mathbf{2 0 0 0}$ & $\mathbf{2 0 0 5}$ & $\mathbf{2 0 0 0}$ & $\mathbf{2 0 0 5}$ \\
\hline & & & & \\
& & & & \\
Denmark & 3.0 & 2.8 & 0.8 & 0.7 \\
Finland & 4.6 & 4.5 & 1.0 & 1.0 \\
Iceland & 11.9 & 12.6 & 0.9 & 1.0 \\
Norway & 1.6 & 1.5 & 0.7 & 0.8 \\
Sweden & 2.3 & 3.3 & 0.7 & 0.9 \\
\hline
\end{tabular}

Source: NIFU STEP

In 2005 the share of R\&D expenditure coming from public funds will continue their increase in all Nordic countries except Denmark.

Table 3.3 Government appropriations for R\&D, by recipient in the Nordic Countries, per cent of total appropriations

\begin{tabular}{|c|c|c|c|c|c|}
\hline & $\begin{array}{r}\text { Base funding } \\
\text { for universities } \\
\text { and similar } \\
\text { institutions }\end{array}$ & $\begin{array}{r}\text { Other } \\
\text { research inst. }\end{array}$ & $\begin{array}{r}\text { Research } \\
\text { councils }\end{array}$ & $\begin{array}{r}\text { Other } \\
\text { pro-grammes }\end{array}$ & $\begin{array}{r}\text { International } \\
\text { org. }\end{array}$ \\
\hline & & \multicolumn{4}{|c|}{ Per cent } \\
\hline Denmark & 51 & 15 & 12 & 17 & 5 \\
\hline Finland & 29 & 16 & 42 & 13 & . \\
\hline Iceland & 37 & 33 & 18 & 8 & 4 \\
\hline Norway & 42 & 10 & 30 & 11 & 6 \\
\hline Sweden & 43 & 38 & 18 & . & 1 \\
\hline Total & 41 & 23 & 25 & 8 & 2 \\
\hline
\end{tabular}

Source: Nordic Council of Ministers.

Table 3.4 Government appropriations for R\&D, by recipient in the Nordic Countries, per cent of total appropriations

\begin{tabular}{|c|c|c|c|c|c|}
\hline & Primary sector & Industry & Public service & $\begin{array}{r}\text { General } \\
\text { scientific } \\
\text { purposes }\end{array}$ & $\begin{array}{r}\text { Defense and } \\
\text { space re- } \\
\text { search }\end{array}$ \\
\hline \multicolumn{6}{|c|}{ 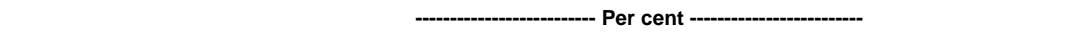 } \\
\hline Denmark & 6 & 7 & 13 & 70 & 3 \\
\hline Finland & 6 & 26 & 21 & 41 & 5 \\
\hline Iceland & 17 & 1 & 65 & 17 & 0 \\
\hline Norway & 9 & 8 & 23 & 52 & 9 \\
\hline Sweden & 2 & 5 & 15 & 57 & 21 \\
\hline Total & 5 & 11 & 19 & 54 & 11 \\
\hline
\end{tabular}

Note: Public service contains the following sectors: transportation and telecommunications, energy, environmental protection, health care, social and cultural services and education.

Source: Nordic Council of Ministers.

There are marked differences between the structure of public expenditure on R\&D in the Nordic countries. Finland allocates a large share of R\&D funding through research councils, while Denmark allocates the lion's share through university or research institution base funding, as can be seen from table 3.3. Similarly, great differences exist between the way 
research is targeted strategically toward different sectors of the economy, as shown in table 3.4. Finland targets much more of its R\&D to industry than other Nordic countries, Iceland targets the primary sectors and public service, Sweden targets defense and space research, whereas Denmark allocates funds to general scientific purposes.

Table 3.5 Higher education institutions' R\&D expenditure by main field of science, per cent, 2001

\begin{tabular}{lccccc}
\hline & Denmark & Finland & Iceland & Norway & Sweden \\
& & - & & \\
& & & & \\
\hline Natural science & 31.4 & 27.5 & 19.9 & 20.6 & 18.4 \\
Engineering & 14.9 & 20.2 & 33.8 & 11.8 & 25.5 \\
Medicine & 13.3 & 24.1 & 12.0 & 29.8 & 28.6 \\
Agricultural science & 6.70 & 2.00 & 8.50 & 5.20 & 5.30 \\
Social science & 17.3 & 17.9 & 15.6 & 21.7 & 13.1 \\
Humanities & 16.5 & 8.30 & 10.1 & 10.9 & 6.00 \\
\hline Total & 100.0 & 100.0 & 100.0 & 100.0 & 100.0 \\
\hline
\end{tabular}

Source: OECD.

Table 3.6 Business expenditures on manufactures by technology level

\begin{tabular}{|c|c|c|c|c|c|c|c|c|}
\hline & \multicolumn{2}{|c|}{ High } & \multicolumn{2}{|c|}{ Medium-high } & \multicolumn{2}{|c|}{ Medium-low } & \multicolumn{2}{|c|}{ Low } \\
\hline & 1991 & 2001 & 1991 & 2001 & 1991 & 2001 & 1991 & 2001 \\
\hline & \multicolumn{8}{|c|}{---- Per cent of total R\&D expenditures ------ } \\
\hline Denmark $^{2}$ & 34.3 & 34.0 & 18.6 & 16.9 & 5.6 & 5.4 & 10.9 & 4.1 \\
\hline Finland & 28.2 & 56.4 & 27.1 & 15.8 & 12.4 & 6.9 & 17.5 & 5.5 \\
\hline Germany & 32.9 & 27.9 & 54.5 & 55.3 & 5.5 & 5.4 & 2.5 & 2.3 \\
\hline Netherlands $^{3}$ & 27.3 & 39.5 & 48.6 & 24.9 & 7.4 & 4.5 & . & 7.0 \\
\hline Norway $^{1}$ & 26.6 & 21.4 & 19.5 & 15.8 & 12.2 & 11.4 & . & \\
\hline Sweden & 47.2 & 55.1 & 31.7 & 26.7 & 3.8 & 2.8 & 5.2 & 2.8 \\
\hline United States $^{3}$ & 46.1 & 39.4 & 21.4 & 19.4 & 5.0 & 3.2 & . & 3.0 \\
\hline EU15 ${ }^{2}$ & 39.7 & 39.7 & 38.2 & 35.2 & 6.5 & 6.0 & . & 3.4 \\
\hline
\end{tabular}

Note: 1: Data is from 1998 instead of 2001. 2: Data is from 1999 instead of 2001. 3: Data is from 2000 instead of 2001 Source: OECD Database, Main Indicators Science and Technology.

Finally, higher education institutions differ much in the Nordic countries with respect to how they allocate their R\&D funds to the main fields of science. Denmark and Finland allocate the lion's share of higher education R\&D expenditure to the natural sciences, whereas Norway and Sweden focus on medicine. Higher education institutions in Iceland spend most on engineering, as can be seen from table 3.5.

Turning now to private sector R\&D, table 3.6 shows the share of business $R \& D$ expenditures in manufacturing of total $R \& D$ expenditures by technology level.

What is clear from table 3.6 is that a great part of business R\&D activities take place in high and medium technology companies, and a very small and declining part in low technology companies. In Finland and Sweden more than half of all R\&D expenditures including public fi- 
nanced R\&D, are undertaken in high technology firms, and more than $3 / 4$ in high and medium technology firms.

According to OECD (2003a p. 17 -18) "in Sweden, the top ten R\&D performing companies account for about half of all business $\mathrm{R} \& \mathrm{D}$, and the top ten performing firms hold approximately $80 \%$ of all patents (IPTS 2002). The R\&D expenditures of Ericsson were equivalent to almost $60 \%$ of Sweden's business R\&D in 1999. In Finland, Nokia was responsible for performing approximately one-third of Finnish business R\&D in 1999, and Nokia's global R\&D expenditures were equivalent to more than $80 \%$ of Finnish business R\&D expenditures in 2001 "

\section{Box 3.1 Definitions of technological level}

The OECD has developed a classification of industries according to their technological level. The classification used is based on two indicators: i) industries' R\&D expenditure as a fraction of value added and ii) industries' $R \& D$ expenditure as a fraction of production. High technology industries have the highest levels of both i) and ii), medium-high technology industries have the second highest levels of i) and ii), medium-low technology industries have the third highest levels of i) and ii), and low technology industries have the lowest levels of i) and ii). A third indicator, R\&D expenditures plus technology embodied in intermediate and investment goods divided by production. However, this third indicator could not be calculated due to data limitations.

The industries identified as high technology industries by means of this procedure are pharmaceuticals, office and computing machinery, radio, TV and communication equipment, medical, precision and optical equipment and aircraft and spacecraft industries.

Medium-high technology industries are chemicals excluding pharmaceuticals, machinery and equipment, electrical machinery and apparatus, motor vehicles and trailers and railroad and transport equipment.

Medium-low technology industries are coke, refined petroleum and nuclear fuel, rubber and plastic products, other non-metallic minerals products, basic metals, fabricated metal products except machinery and equipment and building and repairing of ships and boats.

Low technology industries are food products, beverages and tobacco, textiles, textile products, leather and footwear, wood, pulp, paper, paper products, printing and publishing and manufacturing n.e.c. and recycling.

Analyses by among others The Danish Ministry of Science, Technology and Innovation (2003) find that the OECD definition fails to identify the knowledge service industry, which has the highest number of employees with higher education, as a high technology industry. They therefore suggest a definition of "knowledge-intensive companies" as workplaces or plants which have at least 5 employees with master or PHD level of education, and these employees constitute at least 10 per cent of the total number of employees at the workplace.

It is therefore quite clear that Sweden and Finland are special among the Nordic countries due to the two major industry drivers. Such companies are not present to the same degree in the other Nordic countries. In Nor- 
way which has to be considered a low intensity R\&D country approximately $40 \%$ of its R\&D expenditures are in high and medium technology firms. This can probably be attributed to the natural resource endowment that affects Norway's industrial structure.

In countries with a high R\&D intensity funded by businesses like Sweden, Finland, and Iceland among the Nordic countries, there is a tendency that only a few sectors account for most of this intensity. In Sweden Information and Communications Technology (ICT), pharmaceuticals, and services constitute more than half of all business R\&D expenditures (BERD). Within the service sector, more than $90 \%$ of Sweden's R\&D occurs in post and telecommunications, computer and related services, and research and development industries (OECD (2003a)). In Finland approximately $2 / 3$ of BERD comes from ICT, pharmaceuticals, and services. The same is true in Denmark and Norway but the composition between the three sectors is different. In Denmark and Norway services is much more relatively more important than in Finland and Sweden.

Even though high and medium technology firms are by far the most R\&D intensive in the Nordic economies, they employ only a modest part of the total work force. The same is true for employment in high technology services. Table 3.7 shows employment in high and medium technology manufacturing firms and high technology service firm as a percentage of the total work force.

Table 3.7 reveals that the high R\&D intensive Nordic countries, except Iceland, have almost the same share of employment in medium and high technology manufacturing firms, and almost at the same level as the EU-15 average. Iceland has a relatively low share, which is to be expected given its industrial structure. In contrast it has a relatively high share in high tech services.

Table 3.7 Employment in high technology sectors in the Nordic countries

\begin{tabular}{|c|c|c|c|c|}
\hline & \multicolumn{2}{|c|}{$\begin{array}{l}\text { Employment in medium-high and high- } \\
\text { tech manufacturing }\end{array}$} & \multicolumn{2}{|c|}{ Employment in high-tech services } \\
\hline & 1997 & 2003 & 1997 & 2003 \\
\hline & \multicolumn{4}{|c|}{-..-- Per cent of total workforce -...-- } \\
\hline Denmark & 6.31 & 6.12 & 3.90 & 4.50 \\
\hline Finland & 6.94 & 6.85 & 3.46 & 4.68 \\
\hline France & 7.10 & 6.50 & 3.57 & 4.07 \\
\hline Germany & 10.83 & 11.04 & 2.83 & 3.32 \\
\hline Iceland & 1.87 & $2.02^{1}$ & 3.70 & . \\
\hline Netherlands & 5.11 & $4.06^{1}$ & 3.05 & $3.72^{1}$ \\
\hline Norway & 5.42 & 4.53 & 3.49 & 3.85 \\
\hline Sweden & 8.62 & 7.03 & 4.04 & 4.85 \\
\hline United States & 5.18 & $4.65^{2}$ & . & \\
\hline EU-15 & 7.64 & 7.10 & 2.94 & 3.49 \\
\hline
\end{tabular}

Note: 1: Data is from 2002. 2: Data is from 2001 Source: Trendchart Scoreboard 2004 


\begin{tabular}{lr}
$\begin{array}{l}\text { Table 3.8 Percentage of GERD performed by } \\
\text { the Government sector in } \mathbf{2 0 0 1}\end{array}$ \\
\hline Denmark & 7.4 \\
Finland & 10.2 \\
France & 16.5 \\
Germany & 13.7 \\
Iceland & 20.1 \\
Netherlands & 13.8 \\
Norway & 14.6 \\
Sweden & 2.8 \\
EU-25 & 13.5 \\
\hline
\end{tabular}

Source:OECD (2004) Main Science and Technology Indicators.

Thus, table 3.7 confirms that business R\&D activities are concentrated in few high technology sectors and that in terms of employment, these sectors are small, but as drivers of the R\&D activities they are vital.

Table 3.8 shows the percentage of total R\&D expenditures performed by the government sector. Not surprisingly it shows that Iceland and Norway have the highest numbers among the Nordic countries. It is not surprising given these two countries also have the highest public expenditures on $R \& D$ relative to business expenditures on $R \& D$. What is surprising though, is the very low percentage of barely $3 \%$ of total expenditures performed by the government sector in Sweden. The reason however lies in the way this is constructed in Sweden. It only entails activities by the central government. An educated guess would be that it would correspond to the numbers of Denmark and Finland.

\section{Human Resources}

The amount of skilled labour plays an important and dual role in the knowledge producing system. Skilled labour is a key input in the R\&D process and at the same time they are essential for the diffusion of knowledge and for the ability to absorb and apply existing knowledge.

About half of the R\&D expenditures go to wages paid to researchers. Efforts to raise R\&D expenditures thus have a very direct effect on the demand for researchers, and, to the extent that supply is more or less fixed in the short run, on the wages to researchers. The wage will increase limiting the real resources available for R\&D activities. Therefore, for increased $R \& D$ expenditures to be effective, the supply of researchers has to increase, as shown in Sheehan and Wyckoff (2003).

As highly qualified personnel is a precondition for $R \& D$ activities and innovation, a common indicator for the number of highly qualified human resources in a country is the share of the labor force with a tertiary education. Another typical measure is total business enterprise R\&D personnel per thousand industrial employments. 
Figure 3.2 Percentage of 25-64 year-olds with tertiary education

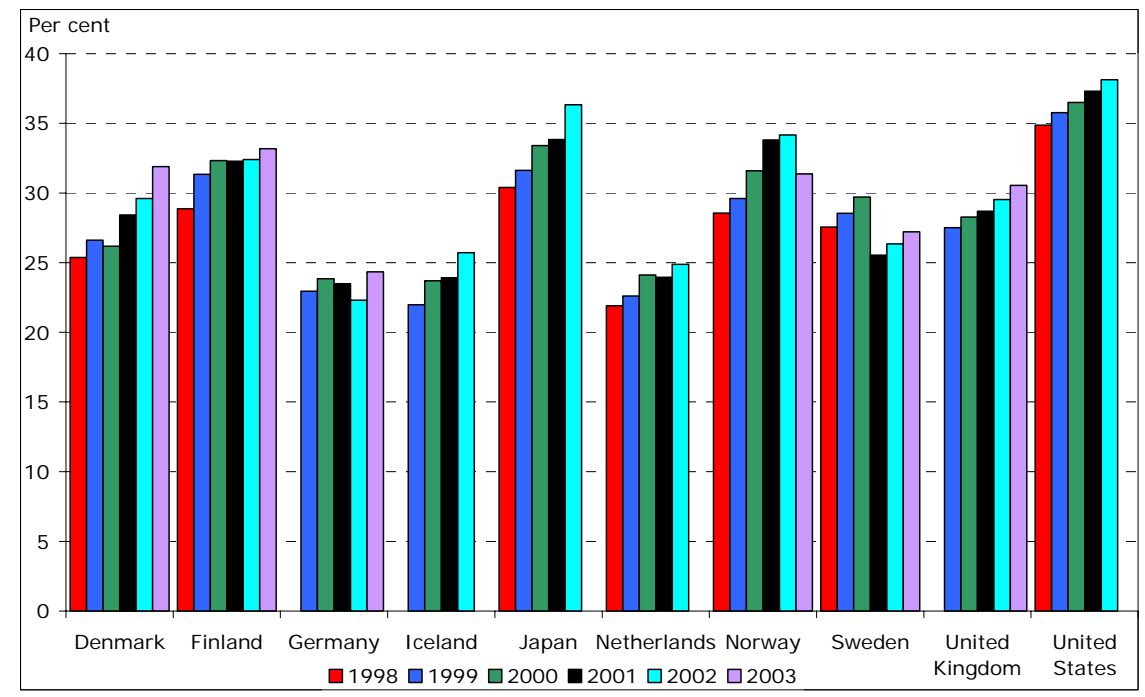

Source: Trendchart Scoreboard 2004

Figure 3.3 shows that for all Nordic countries the number is high in international comparison. The number for EU-15 was 22 per cent in 2002. USA had 38 per cent and Japan 36 per cent of the labor force with tertiary education in 2002.

An econometric study by OECD (2005) demonstrates the importance of skilled labour for all stages of the innovation process. In particular the share of scientists and engineers in total employment seems to be important. Evidence from the third community innovation survey (CIS39 also suggests that for firms to be successful innovators they need a certain proportion of skilled researchers. The fall in the number of science and engineering ( $\mathrm{S} \& \mathrm{E}$ ) graduates that is observed throughout Europe in the 1990 's is therefore a cause of concern.

The educational system thus plays an important role in the process of knowledge production and diffusion, for example by strengthening the R\&D capacity and thus by contributing to the overall competitiveness of a country. Hence, education and labour market policies are key ingredients in increasing the level of innovative activities.

In the Nordic countries (data not available for Iceland) the number of researchers per thousand employees increased markedly from 1995 to 2003. Most impressively in Finland, which saw an increase from 4.8 to 15.1 in the period. All the Nordic countries lie above EU-15 average and hence follow the trend that the Nordic countries perform well on R\&D activity measures. 
Figure 3.3 Business Enterprise researchers, 1995 and 2003

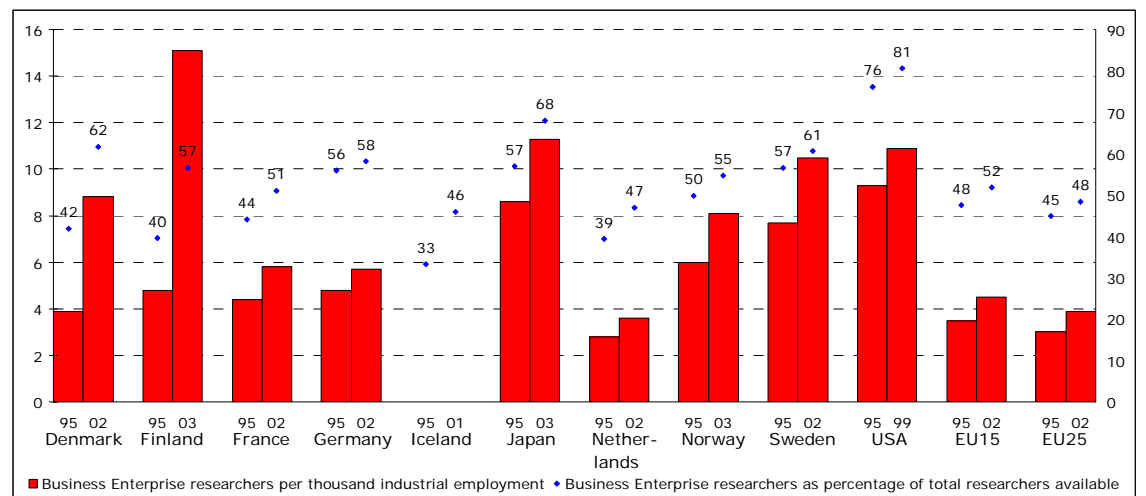

Note: If 2003 not available newest available data used Source: OECD (2004a)

The concern that there are too few S\&E graduates may still be present. Finland and Denmark have seen a decrease in the percentage of graduates from S\&E whereas Sweden has experienced the opposite. The time period is however too short to draw any conclusions regarding the trend.

Table 3.9 University graduates as percentage of total graduates

\begin{tabular}{|c|c|c|c|c|c|c|}
\hline & \multicolumn{3}{|c|}{ Science } & \multicolumn{3}{|c|}{ Engineering } \\
\hline & 1998 & 2000 & 2001 & 1998 & 2000 & 2001 \\
\hline & & -.----- & cent--- & -...-..- & & \\
\hline Denmark $^{1}$ & 12.9 & 12.6 & 6.7 & 9.8 & 8.9 & 9.0 \\
\hline Finland & 8.0 & 7.9 & 7.2 & 24.2 & 24.0 & 20.8 \\
\hline France & 15.9 & 18.0 & 18.2 & 12.9 & 11.2 & 11.2 \\
\hline Germany & 14.7 & 13.5 & 13.2 & 20.1 & 19.0 & 18.4 \\
\hline Iceland & 13.1 & 10.7 & 11.0 & 5.9 & 7.1 & 6.5 \\
\hline Japan & 4.4 & 4.4 & 4.6 & 21.6 & 21.3 & 21.2 \\
\hline Netherlands & 5.7 & 4.8 & 5.2 & 12.1 & 10.4 & 10.5 \\
\hline Norway & 3.8 & 6.3 & 6.8 & 9.0 & 6.8 & 8.3 \\
\hline Sweden & 9.0 & 8.5 & 9.4 & 16.2 & 20.5 & 21.5 \\
\hline United States & 9.2 & 9.3 & 9.4 & 7.0 & 6.5 & 6.4 \\
\hline
\end{tabular}

Note: 1: 1999 instead of 1998

Source: OECD (2004a)

Norway has by Nordic measures few S\&E students and graduates. There may be several explanations of this. These may be according to S.J. Herstad (2005): the relative low wage levels for engineers that historically have been a source of competitive strength for the Norwegian industrial system (Klette and Møen (2002)); another partial explanation may be weaknesses in physical sciences and mathematics education at the primary levels, the latter reflecting problems in recruiting competent teachers. Yet another plausible explanation may be that the petroleum sector, traditionally an important and well-paying employer for S\&E graduates, increasingly is viewed as being in decline and/or involving stationing abroad. The 1999 near bankruptcy of Saga Petroleum, followed by its take-over by Norsk Hydro and subsequent layoff of engineers, has probably contributed to this. 
In all the Nordic countries there is a relatively abundant supply of highly skilled personnel compared to the EU average (see figure 3.2). This is somewhat surprising given that the Nordic taxation system has been and still is clearly geared towards income equalisation, making the pecuniary incentive to undertake a further education fairly low. Studies by The Danish Economic Council (2003) and Ljunglöf (2004) for Denmark and Sweden respectively show that the private return to education is low. Hence, it might seem that the decision to educate oneself is more driven by an increased probability of obtaining a job rather than a rational decision to gain returns to education.

\subsection{Outputs of the Knowledge Producing System in the Nordic Countries}

There might be many indicators of output from the knowledge producing system but a common indicator is the number of patents, though as explained above it is not a perfect measure.

Table 3.10 shows the number of patents applied for per capita at the European Patens Office (EPO) and at the United States Patent and Trade Mark Office (USPTO) both in total and for high-tech industries ${ }^{2}$. Patents per capita have risen markedly in all countries over the short period. Table 3.10 also reveals that there is a tendency that countries with high R\&D expenditures, especially high business R\&D expenditures, have the highest rates of patents per capita. An exception is Iceland which seems to have a low patenting rate despite high R\&D expenditures.

Table 3.10 Patent activity in the Nordic countries

\begin{tabular}{|c|c|c|c|c|c|c|c|c|}
\hline & \multicolumn{4}{|c|}{ Patent applications } & \multicolumn{4}{|c|}{ Patents granted } \\
\hline & \multicolumn{2}{|c|}{ EPO high-tech } & \multicolumn{2}{|c|}{ EPO } & \multicolumn{2}{|c|}{ USPTO high-tech } & \multicolumn{2}{|c|}{ USPTO } \\
\hline & 1996 & 2002 & 1996 & 2002 & 1996 & 2002 & 1996 & 2002 \\
\hline & \multicolumn{8}{|c|}{ 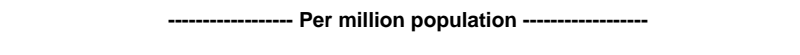 } \\
\hline Denmark & 13 & 45 & 130 & 215 & 5 & 16 & 48 & 84 \\
\hline Finland & 49 & 120 & 174 & 311 & 15 & 51 & 87 & 159 \\
\hline France & 12 & 32 & 100 & 147 & 8 & 12 & 48 & 68 \\
\hline Germany & 16 & 46 & 178 & 301 & 7 & 16 & 84 & 137 \\
\hline Island & 2 & 43 & 30 & 122 & 0 & 22 & 17 & 58 \\
\hline Japan & 22 & 40 & 101 & 167 & 50 & 75 & 184 & 274 \\
\hline Netherlands & 23 & 93 & 136 & 279 & 11 & 15 & 52 & 87 \\
\hline Norway & 5 & 23 & 87 & 131 & 3 & 6 & 31 & 55 \\
\hline Sweden & 36 & 75 & 218 & 312 & 17 & 38 & 97 & 187 \\
\hline United States & 24 & 48 & 107 & 155 & 41 & 76 & 231 & 301 \\
\hline EU-15 & 12 & 31 & 97 & 158 & 5 & 11 & 45 & 71 \\
\hline
\end{tabular}

Source: Trendchart Scoreboard 2004

\footnotetext{
${ }^{2}$ Data from USPTO are numbers of patents granted whereas it for EPO is the number of applications.
} 
With the exception of Norway all the Nordic countries perform better than the EU-15 average. In particular Finland and Sweden have outstanding performance on this measure. Relative to the EU-15 average, they have almost doubled the number of patents at USPTO, and Finland has even four times the EU-15 average in high-tech industries at the EPO.

Figure 3.4 Triadic patents per million of business R\&D spending, constant prices

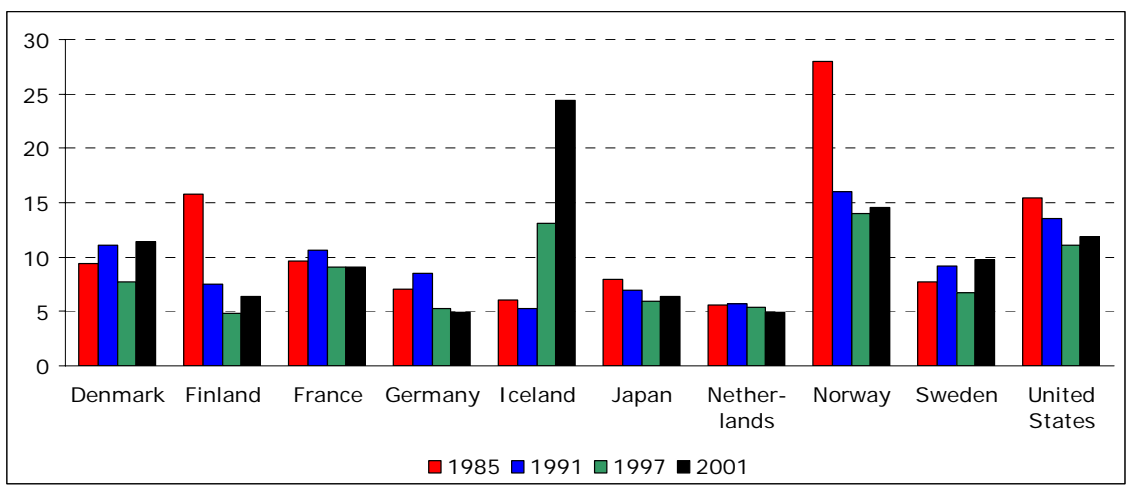

Note: Million 2000 dollars - constant prices and PPP. Triadic patents are patents granted at the US Patent and Trademarks Office, the European Patents Office and the Japanese Patents Office.

Source: OECD Database, Main Science and Technology Indicators.

The number of patents that each country applies for and are granted is an imperfect measure of the output of R\&D activities as argued in appendix C. The European Commission has made a Community Innovation Survey (CIS3) covering all EU member states plus Norway and Iceland. They have, based on questionnaires to firms, established other kinds of indicators of innovative activity than patents.

According to CIS3 an innovation is defined as the successful introduction of a new or significantly improved product or process.

What can be seen from table 3.11 is among other things that having large $R \& D$ expenditures is not a sufficient criterion for being successful. Sweden and Finland that by far have the highest R\&D expenditures do not have the highest rate of successful innovations. In fact the Nordic countries, except Iceland, do not perform above average on this indicator. Furthermore figure 3.4 does not seem to reveal a significant relationship between successfulness and intramural $R \& D$ spending.

There are however according to the definition of an innovation different ways of being successful. The definition does not distinguish between "true" innovation and imitation. A "true" innovation is new to both the firm and the market whereas an imitation refers to an innovation that is new to only the firm. In principle, the innovation can be a new product or a new process. In the CIS3 survey data on "true" innovation and imitation they consider only new products; not new processes.

It is likely that what is more important to long run productivity growth is "true" innovations. On the other hand, the role of imitations should not be underestimated in their effect of increasing the absorptive capacity of the economy. 
Table 3.11 Percentage of revenue created by sale of products, new to the market or to the company, pct

\begin{tabular}{lr}
\hline & $\mathbf{2 0 0 3}$ \\
\hline Denmark & 20.1 \\
Finland & 32.0 \\
France & 17.5 \\
Germany & 29.7 \\
lceland & 4.9 \\
Japan &. \\
Netherlands & 17.7 \\
Norway & 8.4 \\
Sweden &. \\
USA &. \\
\hline
\end{tabular}

Source: Trendchart Scoreboard 2004

Table 3.11 reveals that the share of revenue generated by innovations in the Nordic countries is not impressive, compared to other countries with which these countries are normally compared. Finland does well, but Denmark, Norway and Iceland do not appear to be very innovative measured by this indicator.

A measurement of the output of public research is difficult. One indicator however is the number of articles published in scientific journals with peer review. This indicator makes some sense since advancements in academia is normally granted on scientific contributions ("publish or perish-principle"). However, the number does not say anything about the quality of the scientific work. But given the hardness of getting comparable data on the quality such as numbers of citations, the number of articles within science and engineering will be considered an indicator of university R\&D output.

In all the Nordic countries the number of published articles has increased, and increased substantially in Iceland and Finland. Sweden has a remarkable high number of published articles, in fact, the highest among the OECD countries. But all the Nordic countries fair well by international standards.

Table 3.12 Science and engineering articles per million inhabitants

\begin{tabular}{lrr}
\hline & $\mathbf{1 9 9 5}$ & $\mathbf{2 0 0 1}$ \\
\hline Denmark & 843 & 931 \\
Finland & 809 & 983 \\
France & 493 & 514 \\
Germany & 467 & 530 \\
Iceland & 591 & 610 \\
Japan &. & 451 \\
Netherlands & 798 & 786 \\
Norway & 678 & 721 \\
Sweden & 1.052 & 1.159 \\
United States & 762 & 705 \\
\hline
\end{tabular}

Note: Germany includes articles from East Germany before 1992 Source: OECD Science, Technology and Industry Outlook 2004, Paris.

Another type of output from the knowledge system is the production of highly educated labour. On this account all the Nordic countries have 
experienced growth in recent years, though the growth rate in Sweden greatly exceeds that of the other Nordic countries, and Norway appears to be a laggard.

Figure 3.5 Doctoral degrees per million population in the Nordic countries

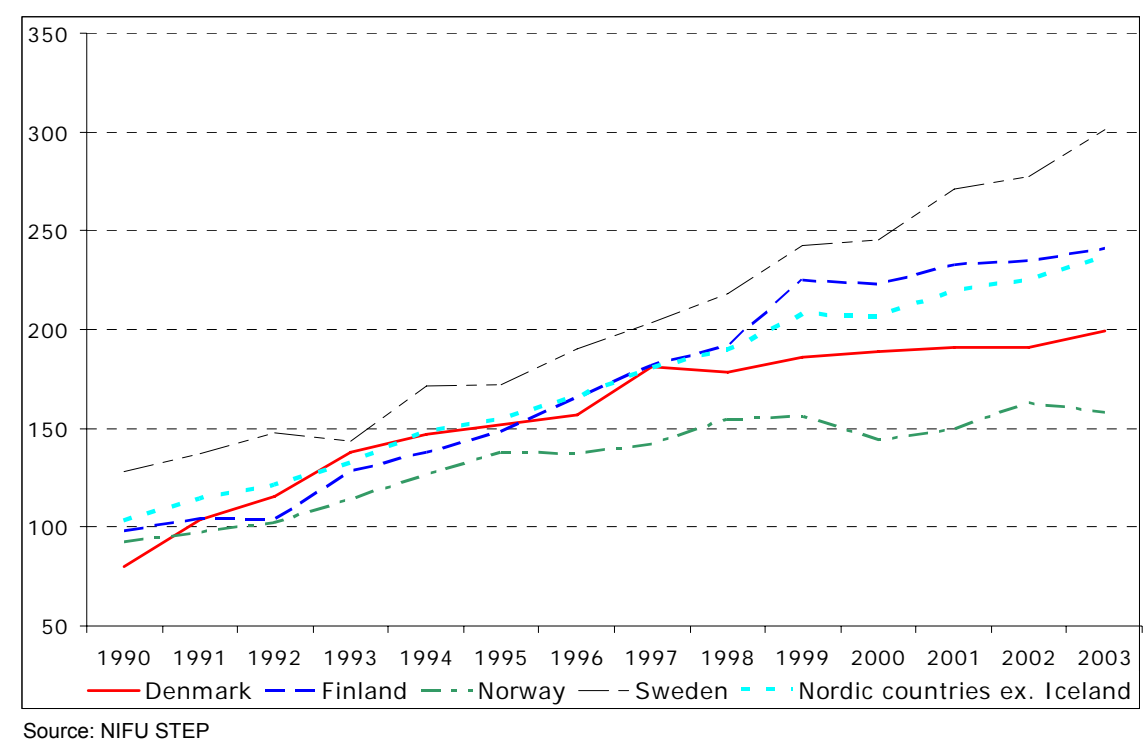

In conclusion it seems that despite the Nordic countries share the same economic welfare model and are all small open economies, there does not seems to exist a common Nordic model regarding R\&D and innovation activities. Finland, Sweden and to a smaller degree Iceland spend high amounts on R\&D in international comparisons, whereas Norway is well below OECD average on R\&D expenditures. Despite Finland and Sweden having large R\&D expenditures this do not translate into an equally high number of successful innovations, and regarding the other Nordic countries their patent rate as well as number of successful innovations are not matched by their spending rate. Even though the Nordic countries except Norway fair well on some indicators by international standards there still seems to be considerable room for improvement, and a large role to play for the public sector in ensuring the right incentives and possibilities for a more successful knowledge producing system. 



\section{Public Sector Research in the Nordic Countries}

Throughout the 1990's there has been a growing pressure for a change in the public knowledge producing system in nearly all OECD countries and certainly in the Nordic countries. This pressure can be seen as a result of increased interest from a variety of stakeholders that have become more active. The stakeholders are, besides the scientific community itself, governments as the main funding party, the business sector and the civil society.

The main interest and stake of the scientific community is to preserve a certain degree of freedom and funding to pursue its research goals and to educate highly skilled human resources. The government has besides the funding aspect an interest in creating the most efficient research and education environment to ensure spill-overs to the entire knowledge producing system and maintain and develop national competitive advantages in times of increased globalization and competition. Often governments tend to be more interested in the output than the research itself.

The business sector's increasing share of funding of R\&D performed in the public research institutions in recent years mirror its growing involvement in knowledge production, and reveals that the business sector has become a more active stakeholder. This development has spurred more connections between public and private research activities and at the same time the distinction between basic and applied research has become vaguer. Moreover, the business sector has a distinct stake in the public scientific system since the latter provides highly skilled human resources to the business sector's increasing R\&D activities.

In the civil society a greater awareness of the public research system has increased its stakes. This increased awareness stems from an expectation that the public system should have answers to new problems of public health, food safety and environmental problems for instance, and that it should be able to create jobs in a globalized world.

All together, governance of public research generally faces new challenges of balancing the diverse and often conflicting stakeholders' interests. As a result there have been a number of changes and reforms that can be organized under four headings: the research priority setting, funding and funding mechanisms, the management of human resources, and the structure of the public knowledge system.

OECD (2004a) has summarized national plans for science, technology, and innovation policies in OECD countries. Table 4.1 is an extract of this for the Nordic countries only. 
Most Nordic countries have launched and to some degree implemented national plans for science, technology and innovation in recent years. Before going into more details about the public knowledge system in the Nordic countries, it might be beneficial to summarize these plans very briefly.

Table 4.1 Summary of national plans for science, technology and innovation policy in Nordic countries

\begin{tabular}{|c|c|c|}
\hline & National plan & Main Objectives \\
\hline Denmark & Knowledge in Growth & $\begin{array}{l}\text { Strengthen Denmark's position as a knowledge- } \\
\text { based society that produces, attracts, dissemi- } \\
\text { nates and utilises knowledge. }\end{array}$ \\
\hline Finland & $\begin{array}{l}\text { Knowledge, Innovation and } \\
\text { Internationalisation }\end{array}$ & $\begin{array}{l}\text { Boost the success of business and society via } \\
\text { innovation, entrepreneurship and expertise. }\end{array}$ \\
\hline Iceland & & $\begin{array}{l}\text { Strengthen S\&T efforts to underpin Iceland's } \\
\text { cultural and economic position in an internation- } \\
\text { ally competitive environment and secure contin- } \\
\text { ued high living standards and quality of life for } \\
\text { Icelanders. }\end{array}$ \\
\hline Norway & $\begin{array}{l}\text { From Idea to Value: A Plan } \\
\text { for a Comprehensive Innova- } \\
\text { tion Policy }\end{array}$ & $\begin{array}{l}\text { Become one of the most innovative countries in } \\
\text { the world, where resourceful and creative enter- } \\
\text { prises and people are given opportunities to } \\
\text { develop a profitable business. }\end{array}$ \\
\hline Sweden & & $\begin{array}{l}\text { Integrate parts of industrial policy and of research } \\
\text { policy; increase commercialisation of university } \\
\text { research. }\end{array}$ \\
\hline
\end{tabular}

Source: OECD (2004a)

\section{Denmark}

"Knowledge in Growth, an ambitious plan to strengthen the Danish knowledge system, was released in January 2003. This White Paper lays out Denmark's overall vision and puts forward a strategy to strengthen Denmark's position as a leading knowledge society which increasingly produces, attracts, spreads and utilizes knowledge. A new Act on Technology and Innovation defines the following aims: $i$ ) co-operation and dissemination of knowledge between knowledge-producing and knowledge-using institutions; ii) development, diffusion, utilization and commercialization of research results, new technology, organizational and market knowledge; iii) development of knowledge- and technology based companies; iv) provision of finance and competence for knowledge- and technology-based companies; and v) international co-operation on the utilization of knowledge and technology. From 2001 to 2004, the government is carrying out a technological foresight pilot program, which will be closely linked to the establishment of a new Future Fund for the development of generic technologies of importance to the nation, including biotechnology, ICT and nanotechnology." (OECD (2004a), p.50).

The Danish government has also appointed the Globalization Council, which by the end of 2005 should prepare a vision and a strategy to make Denmark a leading country in the fields of growth, knowledge and entrepreneurship. 


\section{Finland}

"Finland's new government emphasizes strengthening expertise and entrepreneurship, recognizing that the keys to maintaining Finland's competitiveness are promoting $R \& D$, raising the educational level of the population, pursuing a co-operative approach to income policy, boosting productivity of the public sector, and speeding application of ICT. The triennial review of the Science and Technology Policy Council, entitled Knowledge, Innovation and Internationalization, found that success in innovation is a key factor for the success of both business enterprises and societies." (OECD (2004a), p.50).

\section{Norway}

"The Norwegian government launched in October 2003 a national policy plan, "From Idea to Value - A Comprehensive Innovation Policy". It addresses general framework conditions for innovation and focuses on five R\&D-related topics: i) raising Norway's total R\&D investments (as percentage of GDP) at least to the OECD average by 2005; ii) pursuing increased quality and internationalization of Norwegian research; iii) stimulating R\&D investments by industry; iv) promoting commercialization of research findings; and v) fostering better interaction between knowledge institutions and the business community." (OECD (2004a), p.52).

\section{Sweden}

"In 2002 Sweden initiated a process to set up a new innovation policy to deal with the so-called Swedish paradox of slow long-term economic growth despite high R\&D spending, primarily by industry. A new strategy for innovation policy calls for integration of parts of industrial and of research policy. The Prime Minister, the Minister of Education and Science, and the Minister of Industry, Employment and Communications argued for an improved innovation system as a way to increase economic growth. One aspect of the debate concerns the commercialization of university research and how to increase it. The results of a technology foresight exercise had considerable influence on the debate on future priorities concerning investments in higher education and research and resulted in the directing of major efforts to research in biotechnology and information technology." (OECD (2004a), p.52).

\subsection{Description of the Public Knowledge System in the Nordic Countries}

The public knowledge system is by and large similar in the Nordic countries. The knowledge institutions comprise universities, government research institutes, authorized technological service institutes, centers for higher education and vocational academies. Universities perform re- 
search, teaching and knowledge dissemination. Government research institutes perform research which aims at providing guidance for public sector decisions. They are typically under the authority of a particular ministry. In addition, they perform a number of monitoring and counseling tasks. Authorized technological service institutes provide counseling to companies against a payment. Centers for higher education and vocational academies provide short to medium length education beyond secondary schooling. Knowledge institutions such as universities generate knowledge through research. They attract knowledge from foreign knowledge institutions and other sectors of the economy through the hiring of academic personnel, participation in academic conferences etc. The knowledge institutions disseminate knowledge through education, cooperation with companies and the public sector, through connections to science parks and innovation incubators and through other kinds of knowledge transfers to the general public.

In addition, all the countries have research councils that act as funding bodies and provide counseling to the government on science policies and government research prioritizing.

A brief description of the main characteristics of the public knowledge system in each of the Nordic countries can be found in Appendix D. In summary it can be seen that differences exist between the Nordic countries in the way the system is organized. Some countries have a large public research institute sector like Norway, whereas others have a small like Sweden. Some countries have had specific government policies and bodies for years like Finland, whereas others like Sweden have just recently begun a establishing structured policies and government bodies aimed at science and technology. But there seems to be a parallel structure with research councils funding both independent research and strategic research. Furthermore, moves away from the collegiate system in universities toward more management like organizations are observed in Denmark and is on its way in Norway. The next section will discuss in more detail the changes that have been made in the Nordic countries' public knowledge system and the challenges it confronts.

\subsection{Challenges and Changes in the Public Knowledge System in the Nordic Countries}

\section{The Challenges and Changes: Research Priority Setting}

The growing number of more active stakeholders combined with changes in the scientific frontier have played key roles in the transformation of the public knowledge producing system. It has witnessed a trend away from mono-disciplinary research performed in either the public or the private system, towards more multi-disciplinary research carried out with inputs 
from a variety of researchers in both the public and the private research sectors.

This trend is not necessarily a sign that research questions have become more complex but is more a reflection of the increased stake in public research from the civil society where societal needs are to solve problems that call for many disciplines to be involved. Problem-solving often requires a multi-disciplinary approach that includes many areas of research beyond natural sciences and engineering; for instance economics, management, ethics, sociology and philosophy within social sciences and humanities. The tendency toward more multi-disciplinary research also reflects the fact that many scientific breakthroughs that changes the research frontier emerge at the borderline between different disciplines; e.g. nanotechnology, ICT, and biotechnology.

With improved framework conditions and new channels for commercializing research results there has been a convergence of interests between the different stakeholders. This calls for new structures in the governance of the public knowledge producing system to reap the full benefits.

Table 4.2 from OECD (2003b) gives an overview of new funding schemes and program instruments that have recently been implemented in the Nordic countries.

Table 4.2 New funding schemes and programme instruments

\begin{tabular}{|c|c|c|c|c|c|}
\hline & Denmark & Finland & Iceland & Norway & Sweden \\
\hline \multicolumn{6}{|l|}{ Promotion of co-operation with } \\
\hline the private sector & + & + & + & + & \\
\hline New centres of exellence & + & + & & + & \\
\hline New foundations/funds (estab- & & & & & \\
\hline lished with public money) & + & & & + & + \\
\hline New problem oriented research & & & & & \\
\hline programmes & + & & + & + & + \\
\hline
\end{tabular}

A major challenge to increased multidisciplinary problem-based research is to ensure that scientific areas that may not be popular today are not washed away. It is important to not forget "soft" fields of science such as e.g. humanities and social sciences, which have their places in the knowledge system, though these areas may have a relatively low profile in the public debate on research and development policy. As examples of the growing focus on "hard" fields of science, the Danish government has specifically targeted three areas in its "Knowledge in Growth" plan: Biotechnology, nanotechnology, and ICT. Iceland targets ICT, nanotechnology and the environment, and Norway prioritizes nanotechnology, ICT, marine research, medical and health research, and energy and environment. It is, however, important to maintain a wide variety of research areas in order to insulate the knowledge producing system from rapid changes in interests and thus funding, and in order to provide the necessary human resources for R\&D activities. 
Another major challenge in regard to multidisciplinary problem-based research is on the one hand to concentrate resources to achieve a critical mass, while on the other hand to ensure a sufficient breadth in research areas since important breakthroughs can come from unexpected sources. Hence, science systems need a certain readiness over a broad spectrum of research areas in order to be prepared for new challenges and in order to be able to absorb new knowledge pushing the frontier and hopefully advancing innovations.

A third challenge has to do with the way universities are typically organized. Most universities have faculties that consist of departments organized after discipline (e.g. biology, chemistry, physics, psychology, economics, law). The reason for this is to create a critical mass and obtain synergy effects within the specific discipline, and also to establish some sort of community spirit in the work place. The challenge arises when new structures are created typically in research centres that go beyond the normal organizational structure, and thus partly separate the researcher from the normal command structure and separates the researcher from his or her teaching environment (provided the researcher has teaching obligations as many university researchers have).

As an example of creating centres of excellence, Finland launched a strategy in 1995 to establish national centres of excellence. The Academy of Finland has defined such a centre as: "a research and researcher training unit comprising one or more high-level research teams with shared, clearly defined research goals and good prospects for reaching the international forefront in its field of specialization. Centres of excellence are selected for a term of six years on a competitive basis, with evaluations provided by international experts" (Academy of Finland, 2000). 26 of such centres have been selected for funding in the period of $2000-2007$. Most of them are co-financed from other sources, including the industry.

A fourth challenge concerns the apparent discrepancy between student demand and the research priority areas. Student enrolment is very high in humanities, social science, business and management whereas research focus is at the moment concentrated on e.g. biotechnology, nanotechnology, ICT in natural sciences and engineering. This has wide reaching implications for the notion of research based teaching. If money are allocated to research areas that do not enroll a corresponding number of students, the quality of teaching might be at stake in areas where enrolment is high but funding scarce. This might in turn jeopardize the necessary supply of human resources for solving the problem-oriented research questions that exactly need these kind of graduates.

As a result of the above, the entire character of the ideal from Humboldt University that many Nordic universities are building upon is also challenged. ${ }^{3}$ There seems to be a differentiation between teaching and

\footnotetext{
${ }^{3}$ The "Humboldt model" for universities stress the importance of a close relationship between research and teaching. According to the model, the research process has value in itself.
} 
research both within and between institutions as a consequence of universities becoming mass educating institutions and the increasing costs and specialization in research, notwithstanding the proliferation of on-line or e-learning education. Does this imply that policies should be developed that leads to a growing differentiation of missions among universities? Such policies have widespread implications for funding, career opportunities and the internal balance of operations.

In Finland, the Finnish Science and Technology Policy Council has been changed such that it now includes members from all the major stakeholders such as ministers and experts from the public and private sectors in addition to members from employer and employee organisations. Also, TEKES and the Academy of Finland have close connections to both the business sector and public research institutions to ensure their involvement in priority setting decisions.

\section{The Challenges and Changes: Funding and Funding Mechanisms}

Governments provide the largest share of funding for universities and other public research institutions (PRI). It is either provided directly by the ministries involved in the funding and managing of such institutions, or funding is delegated to intermediary agencies such as research councils. Funding is typically divided into two categories: institutional funding and project funding. Institutional funding are block funds that are allocated annually to research performing institutions, and they do not have any conditions attached to them. Institutions are free to use them in any way they find suitable. Basic research is normally funded by this mechanism. Project funding is as the name suggests connected to specific projects, and is normally granted based on competitive applications from researchers or research institutions. A third funding mechanism, which is also based on competitive criteria, is through special programs either to advance specific research sectors or to promote excellence in general.

Universities and other PRI's institutional funding schemes can come in different varieties but they are usually based on some kind of measure of student enrolment or the number of courses completed, although in recent years, the funding mechanism has changed as a wider and more diverse range of criteria are used. Though in principle institutional funding is block funds without any strings connected to them, they are however constrained by overall science policies, legislation and regulation. For instance regarding salaries or as in Denmark the number of professors that a university is allowed to appoint.

Since stakeholders in the public research system have become more active and greater autonomy in principle has been granted to the public research institutions, accountability to these stakeholders is a much larger theme nowadays than it used to be. It has led to a change in the funding mechanisms to public R\&D. Government funding is now to a larger extent based on contracts, missions and certain performance criteria, and 
requires networking and cooperation between institutions and multidisciplinary research. At the same time funding instruments are becoming more competitive.

Almost all Nordic countries have been implementing and are continuously developing performance agreements with their institutions for funding. These performance agreements do not only rely on, for instance, student numbers but a number of performance based criteria such as student graduates, completion of PhD's and fulfillment of certain other criteria. The agreements have to be negotiated and regularly renewed.

Also new ways of funding have been launched in several countries. Sweden, Denmark and Norway have established public foundations whose interests should be spend on public research; typically within specific research areas defined by the government.

The business sector has over the last couple of decades increased its funding of public R\&D including expenditures to higher education, as described in OECD (2003b).

Although numbers are still relatively small, Iceland has experienced an impressive increase in business funding of higher education. But also the other countries have experienced substantial increases.

Most of this funding from businesses come from project funding and is as such attached to a specific research project or on a broader level to centres of excellence.

In general a change to more project based funding poses some of the same challenges as mentioned in the section above regarding new organizational structures within an existing organization, and most prominently the problems of securing breadth and diversity in the research portfolio. In a publication from OECD (2004b) called "University Research Management" OECD writes: "The growth in defining priority areas for funding has led to the disproportionate favoring of fields of research with perceived strategic importance for economic growth and with obviously "useful" - frequently commercially significant - application. Life sciences, medicine and IT continue to absorb huge funds as do military research in several countries. The less fashionable fields, such as the arts and non-commercial languages, and newly emerging research fields, are frequently under-funded, at least from the institutional perspective. This poses a challenge to those institutions which aim to achieve a diversity of research within the institution. Most important, perhaps, there is a serious distortion occurring in intellectual culture and in the fundamental mission of the university as a major source of values and disinterested inquiry. One approach is for institutions to achieve a sufficiently wide range of resources such that adequate discretionary funds exist to support a good spread of institutional research - but, as a number of the case studies show, it is becoming increasingly difficult to build up and maintain discretionary funds". This is a serious challenge that calls for some concern among policy makers. 
Another general challenge relates to the fact that many funding bodies are increasingly supporting only a part of the cost of research or they are only covering marginal costs. However, research infrastructure is imperative for research to be undertaken and to the extent that external funding bodies do not cover this, it has to be financed from university block funds. But as project funding is becoming more widespread, there is a pertinent risk that underinvestment in equipment will result, and in some cases it already has. Even though underinvestment in infrastructure is not immediately critical it will eventually be so over the years.

Furthermore, the reliance on external funding from businesses presents yet another challenge; namely that of independence of the public research system from economic interest and its ability to preserve its integrity. OECD (2004a) writes in their report "Governance of Public Research p. 21: "As the research community pursues research with more tangible economic rewards, business, government and the general public must be able to maintain their trust in the quality and objectivity of research results. Strong frameworks are therefore needed to guard against potential conflicts of interest, promote ethical conduct, and create incentive structures that reward research that extends the knowledge frontier along a broad front".

Finally, the increase in business funding and cooperation with the business sector entails greater vulnerability of the science system to the business cycle and to sudden changes in business strategies.

\section{The Challenges and Changes: The Management of Human Resources}

In the Nordic countries the number of people seeking tertiary education has never been higher. Nevertheless concerns may be raised as to the supply of human resources into R\&D. There has been a tendency to observe falling numbers of science and engineering ( $S \& E$ ) students in the last $15-20$ years, although in the very recent years the number of $S \& E$ students has begun to increase in Finland and Sweden in particular. However, given the interest and funding available within S\&E there still seems to exist excess demand in future.

The reasons for the decline in the number of S\&E students is not well understood but may involve factors such as low status among peers (considered boring or nerdy, too much mathematics etc.), future job possibilities, and it may not be attractive to obtain a research career due to the lack of attractiveness of being employed in public research institutions.

In 1996 Finland began a program called LUMA (an acronym that in Finnish means natural sciences and mathematics). The aim is to improve teachers' mathematical and science knowledge to an international standard. This is done by various means such as developing teaching material to be used in class rooms and to develop experiments as well. Also, Finland has revised and redesigned curricula in S\&E programs, established new science centres and science exhibitions. Similar things have been observed in 
Denmark where there on main pedestrian streets in major Danish cities is the yearly science day with items such as "stand-up science".

The challenges in ensuring more $\mathrm{PhD}$ students lies not so such in too small a pool of possible $\mathrm{PhD}$ students since the number of students is the largest ever. The challenges lie more in the university system and the management of human resources. Since more and more research is funded by project funds, more and more researchers are employed by fixed term contracts on the specific project. This may seem unattractive to the individual researcher. And if he or she wants to get a prolongation he or she should engage actively in searches for more funds. This is a time consuming task and removes focus from research.

In e.g. Sweden, Denmark and Norway specific funds have been set aside to $\mathrm{PhD}$ positions and promotions for young researchers; both in terms of direct stipends and through specific programs for young researchers via the research council system. In Finland, a new graduate school system was introduced in 1995, and also a program for post doctoral studies has been launched.

Another challenge relates to the tendency that more funds and interests are in multidisciplinary and project based research areas. This is in itself not a problem but promotions within the university system are based on a proven record of academic excellence within a discipline. Even though the number of scientific journals has proliferated, they have done so in a manner that is more and more specialized such that there are journals on very discipline specific topics; but not in interdisciplinary topics. Hence, it is difficult to publish and advance in a multidisciplinary academic system.

There is no data available to see the actual working load divided between teaching and research. But it has become more common especially with the widespread use of researchers employed in fixed term contracts to observe research-only employees at universities. This of course has spill-over effects to the remaining who has to fill the teaching load. Again, the Humboldtian ideal of the unity of teaching and research is challenged. Should the university system allow more division of labor and exploit comparative advantages more such that those who find it attractive to teach (and are good at it) teach more and others do more research?

A similar challenge relates to the new knowledge dissemination task of universities. The universities have recently been assigned the additional task of disseminating knowledge. However, the reward structure for higher education research and teaching personnel has not changed to facilitate the achievement of knowledge dissemination. It is a major challenge for politicians and university managers to design proper incentives for university personnel to disseminate their research results.

Typically, salaries to researchers in public institutions are fixed by government regulation with only small possibilities for individual allow- 
ances. Furthermore, these salaries are typically lower than in the private industry. A more flexible public wage system is an obvious challenge.

A final challenge concerns the age structure in universities. In Sweden almost $75 \%$ of professors are of age 50 or above. Half of all senior lecturers and professors are expected to retire within the next ten years. Similar problems can be detected in other Nordic countries.

\section{Challenges and Changes: The Structure of the Public Knowledge System}

As the trend has changed over the last decade to more and more external funding of public research activities, and to a higher importance attached to multidisciplinary research topics, the structure of the public research institutions has changed as well. In fact, the entire public knowledge system has changed. There has been a tendency in all Nordic countries that universities have been granted greater autonomy and flexibility, that the research councils have been restructured to promote more multidisciplinary research, and that more funds are project funds either directly from the ministries or from the research councils.

The greater flexibility and autonomy that has been granted to universities and research councils implies that the need for accountability to the stakeholders has increased, and as such funding principles and evaluations become important issues.

Almost all project based funding is competitive and based on peer review. This of course has the obvious advantage that only the supposedly best applications receive the funding. The flip side of the coin is that there is a tendency that only those researchers that have a proven record of successful completions of projects are awarded again. It might therefore be difficult for newcomers to obtain funding. Another drawback is that applying for grants is particularly time consuming and many researchers might be discouraged to apply for funding due to the time and effort it takes - time and effort that most often have alternative uses with higher value. Hence, there is a delicate balance between promoting a competitive bidding process through project funds and allowing the necessary time and money for research. It could thus be doubted whether the increased reliance on project funding is optimal in relation to getting the most research for money.

There is little theory and evidence which examines in detail the importance of competition in the funding of research. A few studies exist, however, which investigate this issue empirically. It should be borne in mind that the causal relationship between research quality and external funding is not clear from the few papers which have been found. It may be that high levels of quality leads to high levels of external funding instead of high levels of external funding leading to high levels of quality of research.

Cherchye and Abeele (2005) is a recent paper, which investigates the statistical relationship between the performance of research programs and 
among other things the share of funding, which comes from research councils. Research output is measured as output of international journal articles, edited books and chapters in books, whereas input is measured as $\mathrm{Ph} . \mathrm{D}$ candidates, post-doctoral fellows, professors, associate professors and other senior staff and funding. The data comes from a comprehensive evaluation of Dutch universities in the period 1996-2000, both years included. Cherchye and Abeele (2005) find that there is a positive correlation between the share of external funding and research output. They interpret the results as an indication that the added assessment, which research projects have to pass in order to obtain external funding, is conducive to quality in research.

Another recent paper by Gulbrandsen and Smeby (2005) analyse the effect of industrial funding of research. They find that researches who receive funding from industry publish more work and achieve greater entrepreneurial success than researchers who do not receive funding from industry.

There is thus some evidence that external funding is positively correlated with the quality of research. More work is needed to determine whether external funding is the cause of high levels of research quality or whether the positive correlation just reflects that good researchers can attract more external funding.

When considering the design of incentives in external funding of basic research, it is useful to recall Lazear's (1997) summary of the implications of economic theory for the design of such incentives. ${ }^{4}$

Box 4.1 Lazear's findings on researcher incentives

1. Under a fixed award structure, less able researchers try harder than more able ones, but their efforts do not suffice to compensate for their low ability. To offset the diminished effort put forth by more able researchers, they should be subjected to tougher standards.

2. Increasing the number of awards while maintaining the expected prize constant reduces effort for both the able and the less able. Awarding many small prizes is likely to be socially detrimental.

3. Young researchers are induced to complete their projects when older researchers are given credit for past jobs well done. The effect is to increase effort among the young but decrease effort among the older researchers.

4. Efficiency can be improved by making awards age contingent. Mature researchers can be given higher awards to offset their tendency to reduce effort. If salary and ability are correlated, tying awards to salary is efficiency enhancing.

5. Holding awards until after the project is completed will induce individuals to complete the project. But late awards may severely limit the kinds of projects than can be undertaken to those that can raise their own capital. An alternative is to award early and make the receipt of future awards contingent on past performance.

\footnotetext{
${ }^{4}$ One finding has been left out, due to limited relevance to the Nordic situation.
} 
6. It pays to emphasize high-risk fields out of proportion to their expected value. Funding high-risk enterprises is especially valuable when the knowledge has longevity. Stressing basic theoretical research can be justified on these grounds.

Lazear's (1997) results imply that more able researchers should be induced to put more effort into writing applications for research funding by setting tougher standards for the able researchers. If researchers with low and high ability compete on even ground, the able researchers will be likely to win research funding even though they do not put forth much effort. Thus, Lazear's (1997) results speak in favor of a "handicap" system in competitions for research funding. If there is "learning by doing" in writing project application, older researchers will ex ante have higher probability of winning research funding, and will thus put less effort into writing applications. This effect can be offset by tying the amount of research funding received when winning a competition for research funding to researchers' salary, provided that older and higher ability researchers receive a higher salary.

Lazear (1997) also finds that for a given total amount of funds for financing research, it is best to finance a few projects which each receive large funding. By doing so, the amount of effort put into writing project applications is maximized.

Concerning the incentives of researchers to complete their projects, Lazear (1997) recognizes the trade-off between on the one hand rewarding the actual completion of projects and on the other hand providing sufficient funding to allow projects with large set-up costs to start. The results of Lazear point in the direction of the use of experience rating in fields where capital expenditure is a major cost of research. Lazear also argues in favor of financing high-risk-high-return fields of science, because frequent reviews of project progress will allow for identification of the projects that will have high returns. It is thus important with public start up capital and public review of project progress for high risk fields of science.

As mentioned above, performance agreements based on performance criteria between the government and the public research institutions have now become common in the Nordic countries. This has happened together with increased flexibility and autonomy in order to increase efficiency of public research funding.

In Norway the new funding model has as performance criteria:

- Completed student credits

- Number of graduates

- Number of international exchange students (in and out)

- Co-funding and research cooperation within the EU and from the Research Council of Norway 
- Number of higher academic positions and scientific publications

Similar criteria can be found in other Nordic countries as well. With an enhanced management culture within universities some or all of these criteria will be passed on to lower levels in the organisation; to faculties and further down to departments, and as regards research cooperation, co-funding and the number of scientific publications they are passed on to individual researchers' bonuses.

While these criteria give strong incentives to pursue the aims set out in governmental science and technology policies, one should be aware of the adverse effects such incentives might have on the tasks undertaken and the outcome of the $R \& D$ process.

While all agree that one of the main goals of higher education institutions is to get students who enrol to complete and graduate and diminish the number of students who drop out, there is a potential danger in basing funding on the number of graduates. Namely the one that too many students pass exams compared to a situation where funding is not based on this criteria. This will lower the average level of skills in a cohort.

The challenge when funding is based on co-funding from other sources is a mentioned earlier, the problem of securing sufficient breadth and diversity in the research portfolio, such that less popular areas are also favoured when resources are allocated within the university. To the extent that this criterion is passed on to the individual level as seems to be the case in some places, the discussion of time spend on different tasks with different alternative values should be taken into account.

It is hard to argue that scientific publications are not important. But when used as a funding criterion special caution is warranted. There is a large literature on measuring the impact of different journals. Not all journals carry equal impact. Some are from a scientific point of view better than others. But how should one article in a very good journal be valued compared to one in a mediocre? Publishing in a very good journal typically takes much more time and effort. Frequent publications in highly estimated journals may not be as frequent as in the more average journals. But does this leave room for those who publish rarely but with impact? Or does it foster a number of average researchers but no "Einsteins"?

Surprisingly there is not a criterion for good and valuable teaching, unless this is confused with the number of graduates. In creating pecuniary incentives, one should be very much aware of the effects these incentives have on the tasks that are not rewarded. There is a tendency that the non-rewarded tasks will be given low priority. Therefore it constitutes a potential problem that the quality of teaching is not in the performance criteria in the Norwegian performance agreement. 


\section{The Common Innovation Infrastructure for Private Sector Research in the Nordic Countries}

Companies generate knowledge through mainly development but also to a lesser extent through research. They participate in the circulation of knowledge between companies and other sectors of the economy through the mobility of labor and participation in R\&D cooperation.

Companies' main motive behind R\&D is to increase the value of their companies to the owners. The value of $R \& D$ to companies depends on a wide range of external as well as internal factors. External factors which can be expected to have great importance are the conditions of the competition in which the companies take part. Other factors relate to the preferences and demands of the companies' customers: Do they value improvements in quality and design and is the demand responsive to changes in the price? Companies are also concerned with the ability to protect their R\&D progress from being mimicked by competitors. Another important external condition for companies' R\&D performance is the thickness of labor markets for R\&D personnel. Thus, the presence of higher education institutions and other knowledge intensive companies matter much for the ability of a company to successfully undertake R\&D. Yet another factor is the access to adequate funding which is necessary both to undertake investments in equipment and buildings, but also to finance the daily activities of the project.

Relevant internal conditions are the scope for cost reductions through improved technical or organizational processes. Companies' ability to undertake product and process innovation depends on their access to knowledge capital such as higher educated employees and other key personnel. Thus, high technology companies and knowledge intensive companies are better equipped to successfully performing R\&D. Companies' networks are also of great importance for their access to the necessary expertise. Companies which interact with knowledge institutions and knowledge intensive companies have an advantage in terms of performing R\&D, because they can draw on a great knowledge base.

Most of the important framework conditions conducive to the business sector's R\&D have been discussed in section 3, both in terms of theoretical and empirical considerations. The next section will discuss some of the major challenges that science and innovations policies are confronted with, and some of the responses that have been made. 


\section{Challenges and Changes: Public/Private Partnerships}

Empirical findings suggest that there are positive spill-over from cooperation between public institutions and private enterprises.

The main reason for an increasing use of public/private partnerships (P/PP) is to achieve greater social benefits than could be accomplished they acted independently. This should happen by:

- Cost and risk sharing

- Commercialization of public research

- Improved knowledge infrastructures

- Exploit the complementarities between public and private R\&D

The following figure shows the expected benefits from P/PP.

Figure 5.1 Expected benefits from P/PP

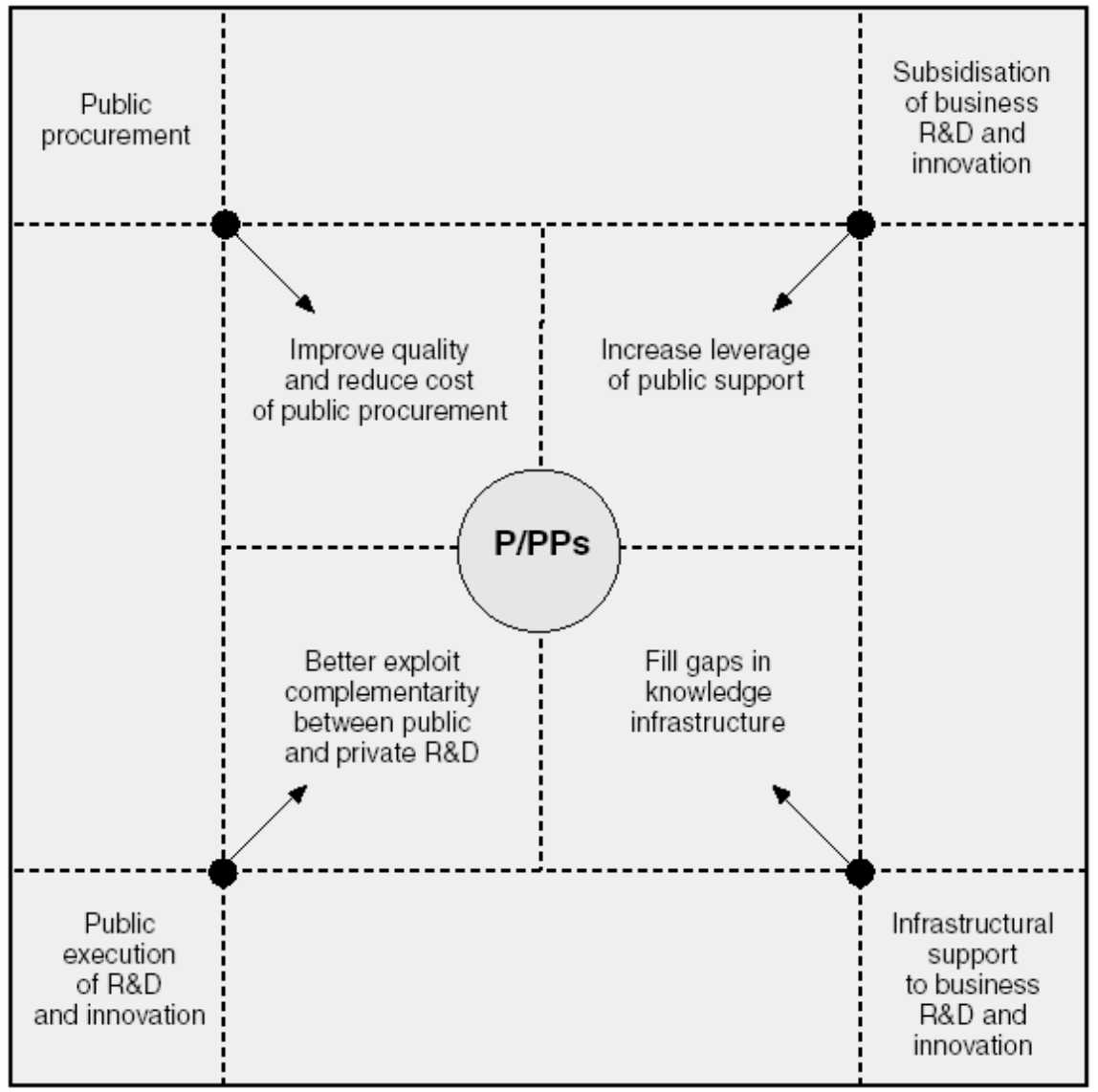

Source: OECD (2004) Science, Technology and Industry Outlook

In all the Nordic countries some form of specific government agencies or foundations that support public/private partnerships are found.

In Finland, The Academy of Finland and National Technology Agency Tekes are the principal public agencies funding research and technology development activities. The public R\&D financing is more 
and more allocated on the basis of competition and also aimed at promoting the $R \& D$ activities of SMEs. Utilisation of international research results and technological development is regarded as a particularly important source of growth for small countries like Finland. The great majority of public research money goes to technology and strategic research. High quality and relevance have been the primary criteria in allocating public $\mathrm{R} \& \mathrm{D}$ resources onwards.

Technology programmes are a central means for Tekes to make strategic choices and steer priorities. The programs strengthen technologies and know-how of primary importance for Finland's future and their businesses based on them. The programs promote cooperation and networking between companies, universities and research institutes, strengthen technology transfer and support international expansion.

In 2003 in Finland, 71 per cent of business R\&D projects cooperated with research institutes or universities. In 2003, companies ordered research services for 32 million euros for their Tekes' projects from research institutes and universities in the form of research subcontracting. (www.research.fi)

In addition, Finnish Science Park Association, TEKEL is a nationwide cooperation network connecting 22 science parks and technology centres in Finland's university cities. The science parks and technology centres accommodate 1600 enterprises and other organisations - bringing together 32000 experts working on different technology fields such as ICT, healthcare and medical technology, biotechnology, environmental and food technology, materials research and digital media. The science parks and technology centres have on their payroll 550 employees. In addition to TEKEL member organisations, there are around 40 (smaller) regional or local technology and innovation centres around the country. Incubators are in many cases linked to a university or a polytechnic and locate often in science parks and technology centres part of the TEKEL network. Koskenlinna (2005) estimates that in 2004 there were some 300 enterprises/entrepreneurs with relations with incubators of the TEKEL network.

In Denmark, ten Authorised Technological Service Institutes (GTS) are main actors in providing knowledge and services to private companies. They are now self-governing institutions working on market conditions with limited public financing, but were previously mainly publicly financed. On an annual basis they sell services to approximately 18.000 Danish companies, but they serve companies from other nations as well. In 2001, they had a turnover of 293 million EUR with approximately half coming from sales to Danish companies. $41 \%$ of the turnover stems from large companies (more than 200 employees).

Denmark also has seven science parks and eight innovation incubators. The latter have contributed to the establishment of 420 start-up companies since 1998 . 
In Iceland, there are several organizations stimulating and/or enabling entrepreneurship. The main organization is Impra, the Service Centre for Entrepreneurship and SMEs. The centre assists entrepreneurs in evaluating business ideas and provides counselling on start-up, growth and management of companies. The Research Liaison Office (RLO) of the University of Iceland (technology transfer office) is a forum for innovation within the academic society. It strengthens ties between university and industry and encourages relations between Icelandic researchers and colleagues in other countries. The RLO has available an incubator centre within the university campus

In Sweden, The Swedish agency for Innovation systems, VINNOVA, runs from May 2003 a seven-ten year long programme to support selected incubators. 14 incubators were selected based on "business criteria such as experience, access to business angels, ownership, and incitement for the management team, and support by the local university" (European Commission (2004), pp. 22-23). The program pays a maximum 50 percent of a grant. The annual budget is $€ 4.5$ million, with $€ 17.7$ million in matching funds.

ITPS (2004) has tried to map actors of the Swedish innovation system. The categories include among others (own translation): "Higher education related actors" (55 actors), "Holding companies" (9 actors), "Technique parks" (33 actors) among them science parks and incubators, and "Technology bridging foundations" (7 actors). There are also numerous actors in other categories. The technology bridging foundations were founded in 1994 with the aim to improve knowledge flows between academia and business. They finance activities such as incubators, seed financing, etc. Recently (July 2004) there has been a restructuring so that they instead of being separate units now belong to the same group, although each of the seven foundations forms a separate daughter company. The new group takes over VINNOVA's incubator programme. The group has a collective budget of 1.8 billion Swedish kronor or roughly 0.2 billion $€$ over the period 2004-2013.

In Norway, Innovation Norway is a state owned company that provides support to private companies in relation to innovation and internationalization. SIVA is a state owned company that is a central actor in a nationwide network of incubators and science parks primarily for entrepreneurs. In addition universities and some university colleges have established a technology transfer office for commercial exploitation of scientific results.

There are of course some major challenges that should be dealt with for P/PP to work properly. The first one is to ensure that both the public institution and private company share the same goals. The goals are not necessarily the same that a private company would pursue on its own. The reason for entering $\mathrm{P} / \mathrm{PP}$ is to increase the social benefits that may or 
may not correspond to the private benefits due to the positive externalities involved in $\mathrm{R} \& \mathrm{D}$ activities.

A second challenge is to get the often rather slow and bureaucratic public system to work more like a private business' net-work based and flexible organisation, and to adapt to best practises for project management. On the other hand, the private company must accept that P/PP's pursue goals that may be different from maximizing shareholder value.

A third challenge is to ensure strict evaluation programs and monitoring to ensure that the research agenda does not develop into neither "blue-sky research" with no market in the end nor the very market oriented research.

Another major challenge is to make sure that public/private partnerships do not contribute to a narrowing of public research areas such that some areas, that may not have a big commercial potential but have a large social value such as many areas within e.g. social sciences, humanities and art, are squeezed out. Furthermore there is a possibility that public/private partnerships results in a biased, however increased, knowledge diffusion if it is primarily larger companies that enter these partnerships. Small and medium-sized companies may not have the necessary resources to go into such arrangements. Even though large firms are empirically found to be the main contributors to $R \& D$, entrepreneurs are often also thought of as a sizeable input to the innovative system. And these may be left behind.

In some Nordic countries, the University Act have been changed (very recently in both Denmark and Norway) to incorporate a closer relationship between universities and the private sector. The other countries already have that in their objectives for universities. By the new university acts it has also been made possible and easier for university researchers to enter into business ventures and universities have been granted the possibility of patenting their results in order to commercialize them.

This of course poses the question of whether research results from public institutions are a public good that should be to the benefit of all. There may be good arguments in favour of this position, and proponents are found in for instance the Danish Economic Council, who in their report from spring 2003 in conclusion writes: "public research results should as a main principle not be patented". On the other hand, if public institutions are to engage in a partnership with private enterprises there need to be some sort of commercialization possible for this partnership to be established at all. The future will show whether these partnerships turn out to be a success; it is still premature to evaluate the success of the changes in the university act.

The challenge is to have innovative systems and policies that are sufficiently flexible to accommodate changes on the research frontier, to be able to adjust and observe new possibilities when they emerge and act accordingly in due time. That seems to be the lesson from the observa- 
tions of the 1990's, where those countries that had high increases in R\&D intensity were those able to swiftly allocate resources into growth markets. This challenge is of course equally valid to private enterprises as well as public institutions and science and technology policy makers.

\section{Challenges and Changes: Access to capital}

Another central role of governments is to provide the necessary access to capital or to create an environment conducive to risk willing capital lenders. The access to capital is an essential necessary input in the R\&D and innovation process.

Financially weak companies may have to accept unfavorable credit conditions in order to obtain funding for innovative activities. Investors or lenders will probably demand various forms of "risk premiums" in return for offering funding. This reduces the incentive to undertake innovative activities.

Thus, companies' financial strength is an important determinant of their potential for successfully undertaking innovative activities. In this situation, different kinds of government support to innovative activities could in principle improve companies' ability and incentive to perform innovative activities.

Venture capital is a mode of finance where the investor participates in the project and makes his or her expertise available. This reduces problems of asymmetric information, because the investor/lender can observe the progress of the project from up close.

Venture capital is particularly well-suited to finance projects in phases where those who initiated the project (the entrepreneur) lack competence in the fields of organization and marketing. The venture capitalist brings this competence along with capital to finance the project and combines this with the entrepreneur's project-specific expertise.

Generally, the problems of access to venture capital are likely to be found in a combination of financial market conditions and conditions for entrepreneurship and risk-taking for individuals, versus the opportunities they are faced with by opting for more secure opportunities in big business or the public sector. As the European Trend Chart on Innovation (2005) views it "it can even be the case that the whole level of seed capital in the total European market is too low".

\section{Challenges and Changes: The Role of Large and Multinational Enterprises}

Multinational enterprises (MNE's) have played an important role in growth and development for decades, and this role seems to have been increasing in the later years.

At the same time it is a general public perception that domestic firms relocate activities or are closed down due to globalization with lower wages in for instance Eastern Europe, China and India, and hence an 
animosity against MNE's. Still however many countries throughout the world attempt to attract MNE's by various policy instruments, and give support to domestic firms' efforts to become multinational. The reason is that it is perceived that MNE's contribute positively to growth through transfer of knowledge, better organizational structures and practices, and increased competition. So far little empirical evidence has supported this politically sensitive perception. But recently studies based on firm-level micro data have been conducted that seem to support this view.

MNE's contribute to a relatively large and increasing share of employment and production in both manufacturing and services, c.f. OECD (2004a).

In both Norway and Sweden the share in manufacturing turnover is between 30 and $40 \%$. In Denmark the share is of approximately $15 \%$. In employment the share is almost 30\% in Sweden, and 10\% in Denmark. In services the share in turnover from foreign affiliates is between 10 and $20 \%$ in 2001.

There are no studies available on Nordic data but a number of studies from the USA, UK and Belgium. The role of MNE's is striking. Corrado et al. (2003) report that in the period from 1995-2000 MNE's in the nonfarm private business in the USA had an annual labor productivity growth of $5.7 \%$ compared to domestically oriented businesses that witnessed annual growth rates of $0.7 \%$. In Belgium, De Backer and Sleuwaegen (2003) find on Belgian data that MNE's hosted by Belgium had marginally higher labor productivity growth rates than Belgian MNE's, but that both types of MNE's had about $50 \%$ higher growth rates than uninational firms.

Other types of studies (Baldwin and Gu (2002)) find that large multiplant firms contribute significantly to enterprise dynamics thus increasing growth. This can happen by various means for instance, increased competition through entry of foreign affiliates, takeover of existing firms, and closure of inefficient ones.

Based on empirical findings OECD (2004a) summarizes some stylized facts as they call them:

- 'MNE's are important contributors to productivity growth

- MNE's are important conduits for technology

- MNE's contribute to growth by stimulating enterprise dynamics"

(OECD (2004a, p. 177))

This of course poses a challenge to policy makers in creating an environment that is conducive to foreign MNE's and to domestic firms becoming MNE's. This should however be completed in a situation where there is growing public concern about job losses due to globalization and outsourcing of activities. 


\section{Challenges and Changes: The Service Sector}

So far in the report not much attention has been devoted specifically to the service sector. But services are the main sector in many industrialized countries. Among the OECD countries services accounted for 70 per cent of total value added in 2000. If one excludes government services, market services alone accounted for $50 \%$ in total OECD value added in year 2000.

Denmark, Sweden and Norway all lost jobs in manufacturing between 1990 and 2001, but they gained in services at almost the same or higher rate. Only in Finland did they lose jobs also in the business service sector.

Services are also an important component of innovation and growth, especially due to the growing use of ICT services. While it is a widespread belief that services do not contribute nearly as much to innovations compared to manufacturing, this belief turns out to be erroneous. In some areas services are more innovative than the average manufacturing firm according to OECD (2004a). Innovations in the service sector appear, however, to be more process oriented than do innovations in manufacturing where they are more product oriented. And they appear to be more small increments in processes, and hence they do not require nearly as much $R \& D$ as do manufacturing $R \& D$. Furthermore, many innovations happen in SME's relatively more often than in the manufacturing sector, though large firms are also more important in services than small firms.

Based on the CIS3 survey 2004 OECD (2004a) has reported a number of interesting findings regarding the service sector, though as OECD (2004a) points out the CIS3 survey result should be read and analyzed with some care since it is a result of voluntary responses by a number of firms throughout Europe. Unfortunately the response rate was not uniform over the countries such that the survey sample has an overrepresentation of German and Italian firms. Nevertheless, the CIS3 survey provides a significant hint about the service sector's importance and below an extract of some interesting conclusions is listed.

- In Iceland the share of innovative firms of all firms within a sector is a little more than 50 per cent for both services and manufacturing, and a little less for both sector in Sweden. In Denmark, Norway and Finland manufacturing has the highest innovative density of the two sectors. The biggest gap is observed in Denmark with approximately 52 per cent in manufacturing and 37 per cent in services.

- Large firms (250+ employees) have the largest share of innovative firms. However, the relation between firm size and innovation is weaker than for manufacturing firms.

- R\&D does not play the same role in services as a key driver of innovation compared to manufacturing. 
- Growth in R\&D business expenditures has been significantly higher in services than in manufacturing during the period 1990-2001.

Average annual growth rates in $R \& D$ business expenditures were 25 per cent in services and 7 per cent in manufacturing in Sweden, and about 10 per cent and 5 per cent respectively in Denmark. Also Finland and Norway have higher average growth rates in services than in manufacturing.

- $\quad R \& D$ is concentrated within the service sector. Business services and post and telecommunications account for more than 75 per cent of R\&D intensity in many countries.

- The service sector employs a larger share than do manufacturing of people with higher education. In Sweden the share of employees with higher education is about four times the share in manufacturing. But in all Nordic countries the share is higher in services.

- The share of newly established firms as a percentage of all innovative firms is larger in services than in manufacturing. Hence, entrepreneurship seems more important in services than in manufacturing.

Thus, polices aimed at improving the innovation intensity within the service sector would not necessarily be the same as those aimed at manufacturing. Previously the innovation policies have been sector neutral, but the growing importance of services and innovation herein has spurred a new set of policies specifically targeted at services. All Nordic countries have undertaken efforts to improve innovation within the service sector by various policy means, primarily in ICT and in developing human skills.

Based on the above evidence the primary challenge seems to be to be aware that innovations in services are often intangible and therefore not as easy to measure and market as product innovations. This fact should not discourage policy makers from fostering and encouraging service entrepreneurship given the huge weight services have in a modern economy.

\subsection{Framework conditions and R\&D output - results from a Danish case study}

Framework conditions such as the general level of technology in the economy, industrial specialization etc. play an important role for the functioning of an economy's knowledge system.

This subsection presents analyses of the relationship between on the one hand firms' value added and framework conditions on the other. ${ }^{5}$

\footnotetext{
${ }^{5}$ An analysis of the relationship between framework conditions and firms' patenting activity has also been performed. The results of this exercise are presented in Appendix E.
} 
Analyses have been performed on the relationship between firms' patenting activity and framework conditions. These results are presented in an appendix to this report. The analyses serve the dual purpose of illuminating some factors which affect R\&D performance and allowing for simulations of the effects of policy measures directed at different framework conditions.

The analysis of the relationship between firms' value added and R\&D input and framework conditions follow the so called production function approach and relates firms' value added to their physical capital, R\&D capital, labor input, other input and other determinants of value added. A brief recent survey of the methodologies used in the literature is contained in Wiese (2001).

The framework conditions investigated in these analyses are the access to highly educated labor, proximity to research and education institutions, own industry R\&D, product market competition and industrial agglomeration. Based on the discussion in chapter 0 one would expect that access to highly educated labor and proximity to research and education institutions is positively statistically related to firms' value added; similarly for own industry R\&D. One would also expect that industrial agglomeration is negatively related to value added for high technology firms but positively related to value added for low technology firms. Finally one would expect product market competition to be related to value added in an inverted U-shaped fashion. The econometric method used for this analysis is OLS.

\section{Data}

The data used for the analyses come from the Danish R\&D statistics developed by the Danish Centre for Studies in Research and Research Policy, the IDA-database and Danish firm data.

The Danish R\&D data relate to $2001 .{ }^{6}$ For this year there is information about firms' R\&D capital stock, the number of R\&D employees and their educational background. The R\&D capital stock has been constructed using firms' R\&D expenditure from 1991 to 2001. Different measures of R\&D capital have been constructed using different rates of depreciation of R\&D capital. For more docu-mentation of the R\&D data, see e.g. Graversen and Mark (2005).

The IDA-database has been used to construct the Ellison-Glaeser index of industrial agglomeration as well as indicators of regional human capital resources. The firm statistics provide information on firms' value added, employment and physical assets, and their provide the data necessary to calculate the Lerner index of industrial competition.

Table 5.1 presents descriptive statistics for the variables used in the analysis of the productivity impact of R\&D.

\footnotetext{
${ }^{6} \mathrm{R} \& \mathrm{D}$ data for earlier years are also available, but require some preparation in order to be applicable. The time available for this project has not allowed for this data preparation exercise.
} 
Table 5.1 Descriptive statistics

\begin{tabular}{lrrr}
\hline Variable & N & Mean & Std Dev \\
\hline Log fixed assets & 2291 & 14.7943 & 5.3890 \\
Log size & 2336 & 2.7536 & 3.2926 \\
Log R\&D_capital & 697 & 14.4858 & 4.1864 \\
Export & 2264 & 22182374.82 & 678124836 \\
Industrial agglomeration & 2341 & 0.0354 & 0.1402 \\
Lerner index of competition & 2196 & 0.9125 & 0.1828 \\
Age (2001) & 2318 & 19,2519 & 13,8051 \\
A/S (public limited company) & 2341 & 0.7663 & 0.4232 \\
Share of pop. w/3 education & 2341 & 0.0634 & 0.0293 \\
Share of empl. in R\&D sect. & 2279 & 0.0051 & 0.0034 \\
Share of empl. in educ. sect. & 2341 & 0.0852 & 0.0103 \\
Dummy for R\&D department & 2341 & 0.0628 & 0.6630 \\
Dummy for R\&D department & 2341 & 0.0628 & 0.6630 \\
Dummies for collaborators & & & \\
In Denmark & & & \\
- Other companies & 2341 & 0.0533 & 0.6141 \\
- Institution of higher education & 2341 & 0.0264 & 0.4380 \\
• Technological service institutes & 2341 & 0.0249 & 0.4261 \\
In EU. Exclusive of Denmark & & & \\
- Institution of higher education & 2341 & 0.0109 & 0.2836 \\
• Other public/private research centers & 2341 & 0.0107 & 0.2814 \\
Outside EU & & & 0.3434 \\
• Same company group & 2341 & 0.0161 & 0.3501 \\
• Other companies & 2341 & 0.0167 & 0.2037 \\
- Institution of higher education & 2341 & 0.0056 & 0.1862 \\
• Other public/private research centers & 2341 & 0.0047 & \\
\hline Source: Statistics Denmark and own calculations & & & \\
& & & \\
& & & \\
\hline
\end{tabular}

Results

Table 5.2 presents the results of the analysis of the productivity impact of R\&D. The analysis included several interaction terms between R\&D capital and framework conditions to test whether selected framework conditions affect the value of firms' R\&D.

The overall results of the analysis are that

- Investments in R\&D capital have a marked positive impact on firms' value added.

- Exports enter the regression with a significant positive effect, which probably reflects the effect of unobserved firm specific characteristics. Much recent research indicates that exporting firms tend to be those that are highly productive and therefore can survive the tough competition in the world market.

- The analysis has tried a large number of interaction terms between R\&D and industry structure, but none of them have been found to be statistically significant. It is somewhat surprising that the industry structure in Danish regions does not appear to affect the relationship between $R \& D$ and value added. It is also surprising that the employment share in the R\&D sector has no significant effect on the relationship between R\&D and value added. Similarly, it is surprising that firms' cooperation with GTS-institutes have no positive effect on value added or on the relationship between $R \& D$ and value added. These results may reflect that the data is insufficient, because they 
cover only one year, and cooperation with research institutions and GTS-institutes materialize after several years.

- The share of the population in a region with tertiary education enters only as an interaction with R\&D capital and with a borderline significant parameter estimate.

Table 5.2 Determinants of firms' value added

\begin{tabular}{|c|c|c|}
\hline Variable & Parameter Estimate & Standard Error \\
\hline Intercept & $5.9747^{\star \star *}$ & 2.1502 \\
\hline Log fixed assets & $0.1312^{* * *}$ & 0.0156 \\
\hline Log size & $0.6854^{\star * *}$ & 0.0211 \\
\hline Log R\&D capital & $0.0889^{\star * *}$ & 0.0183 \\
\hline \multicolumn{3}{|l|}{ Framework conditions } \\
\hline Industrial agglomeration & $-0.8262^{*}$ & 0.4481 \\
\hline Share of empl. in educ. sect. & -2.6844 & 2.5437 \\
\hline Share of empl. in R\&D sect. & -5.6606 & 8.9843 \\
\hline Share of pop. w/3 education & 0.3961 & 1.0501 \\
\hline Industry R\&D capital/value added & -0.5365 & 0.7133 \\
\hline Competition & $13.0577^{* * *}$ & 4.8645 \\
\hline Competition squared & $-8.6983^{* * *}$ & 2.8684 \\
\hline \multicolumn{3}{|l|}{ Dummies for collaborators } \\
\hline With dom. firm in corporate group & 0.0122 & 0.0646 \\
\hline With other dom. firm & $0.1130^{\star *}$ & 0.0524 \\
\hline With DK GTS-institute & $-0.1114^{*}$ & 0.0574 \\
\hline With DK institution of higher edu. & -0.0845 & 0.0619 \\
\hline With DK research institution & -0.06495 & 0.0792 \\
\hline With EU firm in corporate group & 0.03405 & 0.0721 \\
\hline With other EU firm & $-0.1631^{* *}$ & 0.0635 \\
\hline With EU institution of higher edu. & 0.0738 & 0.0990 \\
\hline With EU research institution & $0.1897^{* *}$ & 0.0922 \\
\hline With non-EU firm in corporate group & -0.0343 & 0.0824 \\
\hline With other non-EU firm & 0.0515 & 0.0781 \\
\hline With non-EU institution of higher edu. & 0.2447 & 0.1514 \\
\hline With non-EU research institution & -0.1937 & 0.1294 \\
\hline \multicolumn{3}{|l|}{ Interactions with R\&D capital } \\
\hline Industrial agglomeration & 0.0618 & 0.9444 \\
\hline Share of empl. in educ. sect. & 2.7640 & 4.1010 \\
\hline Share of empl. in R\&D sect. & -1.7473 & 12.0135 \\
\hline Competition & -19.9527 & 31.4006 \\
\hline Competition squared & 12.7050 & 17.7990 \\
\hline Share of pop. w/3 education & $0,0000^{*}$ & 0,000 \\
\hline Industry R\&D capital/value added & 0,0305 & 0,04891 \\
\hline Foreign owner & 0,0000 & 0,0000 \\
\hline With dom. firm in corporate group & 0,0000 & 0,0000 \\
\hline Col. with other dom. firm & 0,0000 & 0,0000 \\
\hline Col. with DK GTS-institute & 0,0000 & 0,0000 \\
\hline Col. with DK institution of higher edu. & 0,0000 & 0,0000 \\
\hline Col. with DK research institution & 0,0000 & 0,0000 \\
\hline Col. with EU firm in corporate group & 0,0000 & 0,0000 \\
\hline Col. with other EU firm & 0,0000 & 0,0000 \\
\hline Col. with EU institution of higher edu. & 0,0000 & 0,0000 \\
\hline Col. with EU research institution & 0,0000 & 0,0000 \\
\hline Col. with non-EU firm in corporate group & $0,0000^{\star * *}$ & 0,0000 \\
\hline Col. with other non-EU firm & 0,0000 & 0,0000 \\
\hline Col. with non-EU institution of higher edu. & 0,0000 & 0,0000 \\
\hline Col. with non-EU research institution & 0,0000 & 0,0000 \\
\hline Interaction: high tech. and ind. agglomeration & 0,0000 & 0,0000 \\
\hline
\end{tabular}




\begin{tabular}{lrr}
\hline Table $\mathbf{5 . 2}$ cont'd. & & \\
& & \\
Variable & Parameter Estimate & Standard Error \\
\hline Control variables & & \\
R\&D department & 7.2484 & 13.7837 \\
Exports & $0.0000^{* * *}$ & 0.0008 \\
Age & $-0.0032^{* *}$ & 0.0016 \\
Foreign owner & 0.0404 & 0.0694 \\
A/S (public limited company) & $0.1109^{* *}$ & 0.0501 \\
Staff less than 50 empl. & 0.5345 & 0.6064 \\
Staff between 50 and 99 empl. & 0.6762 & 0.5833 \\
Staff between 100 and 249 empl. & -0.0442 & 0.5667 \\
\hline Note: $* * *$, ** and * indicate that the estimate is significant at the 1, 5 or 10 per cent level. & \\
Source: Own calculations. & & \\
\end{tabular}

To get an impression of the economic significance of different R\&D related policies, two different policy simulations have been performed. In the first, DKK 1 billion has been spent on increasing the share of the population with tertiary education. In the second, DKK 1 billion has been spent on a subsidy to private firms R\&D.

The first simulation was performed using data for the cost of one year in the Danish education system. The data is the so-called student taximeter, which higher education institutions are paid per student-norm-year they produce. ${ }^{7}$ The costs differ for different levels of education. We assume that the DKK 1 billion is used to provide people with short further education, which normally takes two years to complete. This yields the maximum increase in the number of people with tertiary education (approx. 6,600, corresponding to an increase of approx. 3 per cent). The increase is assumed to be evenly distributed across the Danish regions. The 3 per cent increase in the share of population with tertiary education leads to a simulated first year effect of 0.2 per cent on firms' value added. This is an economically significant effect indeed. However, there are some caveats:

- The simulated effect is based on a borderline significant parameter estimate.

- It is uncertain whether it is possible to provide so many more people with education at the assumed fairly low cost.

- The parameter estimate was based on both individuals with short, medium length and long further education, whereas the simulated increase in the population share with tertiary education came from an increase in the number of people with short further education.

- There are other costs of education besides the pure public-finance effects, e.g. foregone earnings.

\footnotetext{
${ }^{7}$ One year in short further education costs approx. DKK 75,000. Short further education takes on average 2 years. There is approx. 220,000 persons with tertiary education in the age groups 15-64 (2001 values).
} 
The second simulation was performed using data on total R\&D expenditure by the Danish private sector (approx. DKK 27 billion in 2001). Estimates from Guellec and van Pottelsberghe (2003) indicate that on average across countries, a one dollar increase in direct public $R \& D$ subsidies to the private sector increases private sector $R \& D$ by 1.7 dollar. Thus, DKK 1 billion is assumed to increase private sector R\&D by DKK 1.7 billion, or approx. 6 per cent. Current R\&D expenditure amounts to approx. 30 per cent of R\&D capital. Thus, DKK 1 billion in direct R\&D subsidies to the private sector yields approx. 1.8 per cent increase in R\&D capital. This leads to a simulated first year increase in private firms' value added of approx. 0.4 per cent. When comparing this effect to the effect of an increase in tertiary education, it is necessary to consider the rate of depreciation of respectively human capital and R\&D capital. There is reason to believe that $R \& D$ capital depreciates much faster than human capital, but we have not dared to guess at the depreciation rate of human capital. 


\section{Common Nordic initiatives}

The Nordic countries are all small open economies which have chosen to design their public knowledge system in a fairly similar way. Besides this, there are important cultural similarities between the Nordic countries. Finally, in some fields of research the Nordic countries may belong to the international elite, in which case the best partners for research collaboration are the Nordic countries.

Small open economies interact much with the surrounding world and exchanges goods, services and ideas to a large extent. On the one hand this brings benefits of knowledge transfer from abroad. On the other hand much of the knowledge generated by domestic firms will leak to foreign firms, potentially reducing the domestic gains to be had from the innovation.

Furthermore, small economies may face problems in attaining necessary critical mass in some research fields. This issue is particularly pressing in a situation where regional policy considerations and the need for knowledge dissemination work to divide academic resources on several smaller units.

The similarities in the public knowledge system relate to the types of institutions present and to the tasks of the institutions. The Nordic countries have all chosen to assign the task of knowledge dissemination to universities and face a common challenge in providing the right incentives for university personnel to share their knowledge with the rest of the community. In the same vein, the Nordic universities share some organisational challenges with respect to the management of increased knowledge dissemination and collaboration with business enterprises.

There are thus some research themes for which Nordic collaboration appears to be valuable, and there are certainly some fields in which sharing of experiences is valuable. Research in the private and social returns to $R \& D$ and in the best ways to design intellectual property rights for small open economies appear to be well suited for a strategic common Nordic research effort. Under this umbrella lie issues such as mobility of researchers, knowledge transfer via exchange of goods and services, the role of public knowledge institutions in knowledge dissemination etc. Furthermore, research in the design of science policy which can achieve regional knowledge transfer while maintaining critical mass in research, or how to best balance these objectives. Another area, where common Nordic research is warranted is within the fields of history and culture. There may be yet other fields where the Nordic countries as a group differ markedly from the rest of the world, and where common research initiatives are warranted. 
It is also of great importance that the Nordic countries share their experiences in meeting the challenges of improving knowledge transfer from universities to business enterprises and of increased public-private collaboration.

The present common Nordic research and development initiatives entail Nordforsk, Nordic Centers of Excellence, and the Nordic Council Culture and Education and Training Committee. Nordforsk has the purpose of making the Nordic countries a leading and coherent research region. Nordforsk has the responsibility for Nordic collaboration in research and researcher education as well as the Nordic Innovation Centre (NICe). Nordforsk has three functions: coordination, financing and policymaking within the areas of Nordic research. Nordic Centers of Excellence have many purposes. They should increase awareness of Nordic research and make Nordic research more active in Europe and the world. They should support creative and effective research and researcher education environments, increase mobility among Nordic researchers and create Nordic critical mass. They should furthermore integrate Nordic top research environments into the national research systems, further multidisciplinary research, and ensure efficiency and specialization among Nordic researchers. So far, four Nordic Centers of Excellence have been formed in 2003 within the area of global climate change, and in 2004, three Nordic Centers of Excellence were formed within the area of molecular medicine.

To our knowledge these common Nordic initiatives have not yet been evaluated, and such evaluations would also be premature at the present time. However, it is possible to offer some points from economic theory regarding the design and purpose of the common Nordic initiatives. Given that the Nordic region is very open, one might ask: why should the Nordic countries aim for research leadership? Leadership is expensive, because 1) it is difficult to absorb knowledge from others: the leader already knows what everybody else do, and 2) leadership requires a large concentration of high quality researchers, which it is expensive to attract due to high taxes on income in the Nordic countries. Furthermore, the openness of the Nordic countries implies that much of the knowledge generated leaks abroad. So: for the Nordic countries there is reason to believe that the costs of scientific leadership are relatively high and the benefits are relatively low - though this is a question that needs to be subject to research and analysis in the future. This topic needs to be analyzed in depth. There are examples of common Nordic research initiatives with outstanding results, e.g. the Nordic Institute for Theoretical Physics, which belongs to the international elite in its field.

The idea of creating Nordic critical mass and enhancing researcher mobility is appealing from the point of view of economic theory. Researcher mobility enhances the common Nordic social benefit of re- 
search, and the goal of creating Nordic critical mass addresses one of the main challenges for the Nordic innovation system.

The Nordic Council Culture and Education and Training Committee also have intuitive appeal from an economic point of view - the Nordic countries have much common cultural background, hence a common Nordic effort in this area seems natural.

In the future, the performance of the Nordic Centers of Excellence and Nordforsk should be evaluated. One possible evaluation approach is demonstrated in Cherchye and Abeele (2005) as mentioned earlier in this report. 



\section{Conclusion}

The general economic performance of the Nordic countries is good. National income per capita is high, unemployment is low, inflation is low, the public budgets are fairly strong and foreign trade performance is good.

One way to summarize the general economic conditions in the Nordic countries is by means of the so-called global competitiveness index. This index comprises information on an economy's general macroeconomic stance, the quality of public institutions and the technological readiness. According to this indicator, the Nordic countries belong to the international economic elite.

The scientific output of the Nordic countries belongs to the international top. However, the ability to put knowledge to commercial use is less impressive. Measured by international patenting activity Finland and Sweden belong to the international top, Denmark performs better than average, and Iceland and Norway perform below average. Another indicator of the ability to put knowledge to commercial use is the share of companies' turnover accruing from the sales of products which are either new to the individual firm or to the market as a whole. This indicator shows that Finland is the only Nordic country in which companies are more innovative than the EU average. Denmark is slightly below the EU average and data is missing for Sweden, but Iceland and Norway perform markedly below average on this performance measure.

Except for Norway the R\&D efforts of the Nordic countries, measured by the amount of money spent on $R \& D$, is above both the EU average and the OECD average. Measured by human resources in R\&D and the share of the population with tertiary education, all the Nordic countries have an $R \& D$ input which is greater than the EU average. The number of researchers in the Nordic countries is also high in an international comparison.

A literature review performed in the report, finds that the framework conditions in the private sector and in the public sector are generally conducive to good $R \& D$ performance in the Nordic countries. However, there are a few problems. Iceland has difficulty fostering competition, and Norway is so specialized in low-technology that it may be a problem for fostering high technology innovation.

Results of a study performed in the report indicate that framework conditions do have important effects on firms' value added, and access to labor with tertiary education has a positive effect on the returns to investment in R\&D. Results from a simulation exercise indicate the government subsidies to private sector R\&D and an increase in the share of 
the labor force with tertiary education will have a substantial effect on firms' value added. It should be borne in mind that these results are from a case study of firms in Danish regions, and may thus not be applicable to the other Nordic countries and there are some important data limitations. One should thus be cautious when interpreting the results.

\section{Common challenges and suggestions for further analysis}

Small open economies like the Nordic countries are much exposed to the conditions of the world market. Final goods, factors of production and knowledge flow easier to and from such economies than what is the case for less open economies. This implies that a large part of the knowledge spill over from research and development will flow to other countries. However, the openness also gives greater potential for receiving knowledge transfer from abroad, provided the necessary absorptive capacity exists.

The Nordic countries also share many characteristics of the public sector's part of the knowledge system. The knowledge systems comprise similar types of institutions with similar overall objectives and roles. The Nordic countries thus face a number of common challenges regarding how to properly stimulate knowledge dissemination from universities to the private sector, how to strike the right balance between allocating funding through strategic research funds and through independent research funds and how to achieve critical mass in research.

The Nordic countries share much cultural and historical background, which opens promising venues for common research. It may also facilitate cooperation in the form of e.g. researcher education.

It is difficult to measure the performance with respect to knowledge transfer, and there are no internationally comparable indicators that allow for this. An approach to evaluate the progress with respect to achieving a higher level of knowledge transfer is to look at the incentives available to public sector researchers for disseminating knowledge.

In none of the Nordic country does knowledge dissemination have a strong impact on the academic career of public sector researchers. Promotions in academia are generally based on the "publish or perish" principle. In several Nordic countries, recent reforms have given public sector researchers improved rights with respect to patenting their inventions. The empirical effect of these measures remains to be seen. Theoretical considerations do not speak clearly in favour of this incentive mechanism, though. The problem is that patents give monopoly rights, which put a limit to the amount of knowledge dissemination that can take place. Recent research indicates that there are better mechanisms available to reward innovative researchers, which make the invention public and thus leads to more knowledge dissemination. Patent buyouts or invention contests are some of the possible mechanisms, which have theoretical appeal. 
When considering measures to increase knowledge dissemination from public sector research to private sector research, it is a challenge to strike the right balance between distributing research resources regionally and maintaining the critical mass necessary to perform high quality research. Presently, no tools exist for analysing the balance between achieving critical mass and disseminating knowledge. It is necessary to develop analytical tools to do so.

The balance between free research and strategic research should also be considered closely. While strategic research promises visible progress in selected areas, a number of drawbacks should be taken into consideration. It is difficult to identify a priori the fields of $R \& D$ that are most promising with respect to increasing national welfare. Robustness to changes in stakeholders' interest is a necessary part of a knowledge system. There is a need for critical mass in many fields of science in order to answer multidisciplinary research questions, and this could conflict with a great emphasis on strategic research.

The EU countries have a stated policy objective that 3 per cent of GDP should be spent on R\&D, and one third of this should be spent by the public sector, by 2010. As shown above, Denmark is still some way from reaching this goal. Reaching the goal will be problematic for Denmark. The gap between the objective and the current R\&D spending is large and the free resources of highly educated research personnel are limited. It is thus hard to envisage a drastic increase in public $R \& D$ spending that leads to a corresponding increase in high quality $R \& D$ output. ${ }^{8}$

One area where the Nordic countries differ much from each other concerns the way public research funding is allocated to researchers and institutions. Finland uses funding through research councils to a great extent, whereas Denmark distributes funds through university base funding. There is a need for further analysis of the optimal way to allocate funds. The few existing studies tend to find that research councils are more conducive to quality of research than university base funding is. This would indicate that channelling additional public funds for R\&D through research councils is better than through university base funding. However, more research and analysis in this area is needed to corroborate or falsify this finding.

Research and analysis is also needed to understand how supra-national research funding from e.g. the EU or from the Nordic Council of Ministers should interact with national public research funding. Should national public research funding fill the funding gaps left by other sources of funding?

\footnotetext{
${ }^{8}$ Norway has not signed the Barcelona agreement, but if Norway should try to attain the Barcelona target, the country would also lack researchers and face even greater problems than Denmark in maintaining the quality of research output while increasing $R \& D$ expenditure.
} 
Finally, the Nordic countries are all small open economies. There is a need for further research into the effects of international knowledge transfer on R\&D performance. Does international knowledge transfer create a demand for special tools for intellectual property protection? Or more generally, how do small open economies like the Nordic best participate in the international division of labor with respect to research, development and innovation?

\section{References}

Aghion, P. and P. Howitt (1998): Endogenous Growth Theory. MIT Press, Massachusetts.

Aghion P., N. Bloom, R. Blundell, R. Griffith, P. Howitt (2002): Competition and Innovation: An Inverted $U$ Relationship, NBER Working Paper 9269, National Bureau of Economic Research

Andersen, A.K. (2000): Commuting Areas in Denmark. AKF Forlaget. København.

Arrow, K.J. (1962): The Economic Implications of Learning by Doing. Review of Economic Studies, 29, pp. 155-173.

Bartelsman, E., Doms, M. (2000): Understanding productivity: lessons from longitudinal microdata. Journal of Economic Literature 38, 569-594.

Baygan, G. (2003): Venture capital policy review: Norway. STI Working paper 17/2003, OECD.

Baldwin, J. and W. Gu (2002): Plant Turnover and Productivity Growth in Canadian Manufacturing. STI Working Paper 2002/2, OECD, Paris.

Cherchye, L. and P. V. Abeele (2005): On Research Efficiency - A MicroAnalysis of Dutch University Research in Economics and Business Management. Research Policy 34, pp. 495-516.

Cohen, W. (1995): Empirical Studies of Innovative Activity. In Stoneman, P. (ed.) (1995): Handbook of the Economics of Innovation and Technological Change. Blackwell, Oxford.

Cohen, W. and D. Levinthal (1989): Innovation and Learning: Two Faces of R\&D. Economic Journal, 99, pp. 569-596.

Cohen, W., R.R. Nelson and J.P. Walsh (2000): Protecting their intellectual assets: Appropriability conditions and why US manufacturing firms patent (or not). NBER Working Paper No. 7552.

Conway, P., V. Janod and G. Nicoletti (2005): Product Market Regulation In Oecd Countries: 1998 To 2003. OECD ECO/WKP(2005)6.

Corrado, C., P. Lengermann and L. Slifman (2003): The Contribution of MNCs to US Productivity Growth. DSTI/EAS/IND/SWP/AH(2003)2.

Gulbrandsen, M. and J.-C. Smeby (2005): Industry Funding and University Professors' Research Performance. Research Policy 34, pp. 932950.

Czarnitzki, D. and G. Licht (2005): Additionality of Public R\&D Grants in a Transition Economy: The Case of Eastern Germany. Economics of Transition, forthcoming.

Danish Economic Council (2003): Danish Economy, Autumn 2003. Copenhagen.

Danish Ministry of Science, Technology and Innovation (2003): Knowledge in Growth. Copenhagen.

De Backer, K. and L. Sleuwaegen (2003): A Closer Look at the Productivity Advantage of Foreign Affiliates. DSTI/EAS/IND/SWP/AH(2003)4.

Dixit A and R. Pindyck (1994): Investment under Uncertainty. Princeton University Press.

Duranton, G. and D. Puga (2001): Nursery Cities: Urban Diversity, Process innovation, and the LifeCycle of Products. American Economic Review, forthcoming.

Eeckhout, J. and B. Jovanovic (2001): Knowledge Spillovers and Inequality. 
American Economic Review, 92 (5), pp. 1290-1307.

European Commission (2004): European Trend Chart on Innovation

- Annual Innovation Policy Report for Sweden. Bruxelles.

Feldman M. P. and Audretsch D. B. (1999): Innovation in cities - Science-based diversity, specialization and localized competition. European Economic Review 43, pp. 409-429.

Geroski, P. (1995): Markets for Technology: Knowledge, Innovation and Appropriability. In Stoneman, P. (ed.) (1995): Handbook of the Economics of Innovation and Technological Change. Blackwell, Oxford.

Glaeser E. L., H. D. Kallal, J. A. Scheinkman; A. Shleifer (1992): Growth in Cities. The Journal of Political Economy, 100 (6) Centennial Issue, pp. 1126-1152

Goolsbee, A. (1998): Does Government R\&D Policy Mainly Benefit Scientists and Engineers? American Economic Review, 88 (2), papers and proceedings, pp. 298-302.

Graversen, E.K. and M. Mark (2005): Forskning og Udviklingsarbejdes påvirkning af produktivitet og beskaftigelse. Rapport for Ministeriet for Videnskab, Teknologi og Udvikling.

Guellec, D. and B. Van Pottelsberghe de la Potterie (2003): The Impact of Public R\&D Expenditure on Business R\&D. Economics of Innovation and New Technologies, 12 (3), pp. 225244.

Halvorsen, T., O. Korsnes, og R. Sakslind (1996): The Norwegian Disconnection: Professional Unity and Industrial Division. In Whitley and $\mathrm{H}$. Kristensen (eds.) (1996): The Changing European Firm: Limits to Convergence Routhledge, London.

Henderson, V. A. Kuncoro and M. Turner (1995): Industrial Development in Cities. Journal of Political Economy, 103 (5), 1067-1090.

Herstad, S.J. (2005): The Norwegian Knowledge System. Arbejdsnotat, CEBR.

Jacobs, J. (1969): The Economy of Cities. Vintage, New York.

Jones, C. I. and J. C. Williams (1998): Measuring the Social Return to R\&D.
Quarterly Journal of Economics, 113 (4), pp. 1119-1135.

Klette, T.J and Møen, J (2002): Vitenskapelig forskning og næringsutvikling (Scientific reserach and industrial development). In Hope, E. (ed.): Nceringspolitikk for en ny økonomi (Industrial policy for a new economy) Fagbokforlaget, Bergen

Koskenlinna M. (2004): Välittäjäorganisaatiot Suomessa - rakenteelliset haasteet.

Koskenlinna M., Smedlund A., Ståhle P., Köppä L., Niinikoski M.-L., Valovirta V., Halme K., Saapunki J., Leskinen J. (2005): Välittäjäorganisaatiot - moniottelijat innovaatioita edistämässä. Tekes Teknologiakatsaus 168/2005.

Kremer, M. (1998): Patent Buyouts: A Mechanism for Encouraging Innovation. Quarterly Journal of Economics, 113, pp. 1137-1168.

Lazear, E. P. (1997): Incentives in Basic Research. Journal of Labor Economics, 15 (1), pp. S167-S197.

Ljunglöf, T. (2004): Livslöner 2002. SACO, Stockholm.

Marshall, A. (1890): Principles of Economics. MacMillan, London.

Mohnen, P. (1996): R\&D Externalities and Productivity Growth. STI Review 18, pp. 39-66. OECD, Paris.

Nickell S. J. (1996): Competion and Corporate Performance. Journal of Political Economy, 104 (4), pp. 724746.

OECD (2002): Frascati Manual - Proposed Standards Practice For Surveys And Research And Experimental Development. Paris

OECD (2003a): Targeting R\&D: Economic and Policy Implications of Increasing R\&D Spending, STI Working Paper 2003/8

OECD (2003b): Governance of Public Research: Towards Better Practices. Paris.

OECD (2004a): Science, technology and Industry Outlook. Paris.

OECD (2004b): University Research Management: Meeting the Institutional Challenge. Paris.

OECD (2005): Innovation policies: innovation in the business sector. Working Party No.1 on Macroeconomic and Structural Policy Analysis. 
Park, W.G. and S. Wagh (2002): Index of Patent Rights in Economic Freedom of the World 2002: Annual Report, the Cato Institute.

Porter, M. (1990): The Competitive Advantage of Nations. Free Press, New York.

Romer P.M. (1986): Increasing Returns and Long Run Growth. Journal of Political Economy, 94, pp.1002-1037.

Schmidt K. M. (1997): Managerial Incentives and Product Market Competition. Review of Economic Studies, 64 (2), pp. 191-213.

Schneider, C. (2005): Indicators of innovative activity. Arbejdsnotat, CEBR.

Scotchmer, S. (2004): Innovation and Incentives. MIT Press, Cambridge, Massachusetts.
Sheehan J. and A. Wyckoff (2003): Targeting R\&D: Economic and Policy Implications of Increasing R\&D Spending. STI Working Paper 2003/8.

Sørensen, A. H.C. Kongsted and M. Marcusson (2005): R\&D, Public Innovation Policy, and Productivity: The Case of Danish Manufacturing. Economics of Innovation and New Technology, 12 (2), pp. 163-178.

Wieser, R. (2001): R\&D and Productivity: Empirical Evidence at the Firm Level. WIFO working paper $158 / 2001$.

World Economic Forum (2004): Global Competitiveness Report. 2004-05. Palgrave Macmillan. 


\section{Appendix A: Nordic venture capital initiatives}

In Norway, insufficient supply of private equity in general and venture capital in particular has during the last years been put forward as a main weakness of the Norwegian institutional system. This resulted in the 2001 establishment of Argentum. This is a government-owned investment company, and the only pure fund-of-fund investor in the private equity sector in Norway. Argentum aims, through its investments, to facilitate access to international venture capital, and to be a main driving force in the development of an internationally competitive private equity environment in Norway. Argentum invests through either established or new fund management structures, the idea being to achieve an arms length relationship between what is basically indirect state ownership and individual projects; thus boosting private equity markets without influencing through state strategic control.

In Finland, The National Technology Agency (Tekes), provides funds for applied technical research and risk-carrying R\&D ventures in industry. In 2004, Tekes provided funding for 2,242 research and development projects in companies, universities and research institutes. The total budget for these projects was 798 million euros, of which Tekes financed 409 million euro. In 2004, 28 per cent of all Government research funding was channelled through Tekes.

In Iceland, there are several financial institutes that, to a varying degree, are active in financing innovative projects. The Biotechnology Fund is an investment company (venture capital / private equity) primarily providing seed and early stage funding within the fields of biotechnology, medicine, and pharmaceuticals. Another relevant organization is the New Business Venture Fund, an independent company owned by the Government, which financially supports innovative projects.

In 1998 the Icelandic New Business Venture Fund began its operations. It is an independent company owned by the Icelandic Government. Overall supervision of the Fund is undertaken by the Minister of Industry and Commerce. The Fund is the outcome of a more thorough reorganization of the banking sector in 1997 where four sectoral credit funds were merged into the Icelandic Investment Bank and New Business Venture Fund (In April 2000 the Icelandic Investment Bank merged with the private bank Islandsbanki.). The purpose of the Fund is to strengthen the Icelandic economy and expand its internationalization. This is to be achieved through participation in innovation-oriented investment projects and by helping to develop marketing skills in companies. The Fund pro- 
vides start-up capital and invests in early stage and expanding companies. Also grants and loans are given.

The main activities of the Fund are divided into segments:

- The Core Fund invests in new business ventures, supports research and development projects and awards venture capital loans for specific projects. The capital base of the Core Fund is ISK 4 billion (approximately $€ 50$ million).

- The Product Development and Marketing Department offers funding for product development and marketing projects.

- The Information Technology Fund supports new business ventures and job creation in the fields of information technology and high technology, focusing on rural regions. The capital base is ISK 1 billion (approximately $€ 13$ million).

- The Export Credit Guarantee Department guarantees loans, investments etc. related to exports and activities by Icelandic parties overseas.

However, since Iceland is small by population, there is limited availability of venture capital in total amounts, which might decrease the number of start-up companies.

In Sweden, ALMI Business Partner consists of a parent company owned by the government, and 21 regional offices. The ALMI group provides funding and consultancy services for business development.

Denmark has two main public sources for risk willing capital. The major one is The Danish Growth Fund that was founded in 1992. It provides seed and development capital to pre-projects by granting equity and loans with variable interest depending on the success of the project. The other main source is a guarantee scheme for development firms where the state insures against losses of up to $50 \%$. The scheme has approximately 130 million EUR and it is at present fully used. 


\section{Appendix B: Short country descriptions}

The following section will try to further describe the industrial structural characteristics of the Nordic countries with special emphasis on features important for R\&D and innovation.

\section{Norway}

The Norwegian industrial system can be described as a dual structure consisting of the large-firm tier that dominate Norwegian exports, and a distinct tier of small and medium sized enterprises (SME) that generate the overwhelming part of Norwegian employment. Whereas a distinction between a large firm and a small firm tier is not uncommon in developed countries, the distinctiveness of the Norwegian system is related to a) the dominance of state ownership in the former tier, b) the emphasis on natural resource based activities in the same; and c) its lack of 'high-tech' locomotives such as Ericsson (Sweden) and Nokia (Finland). Natural resource specialisation extends beyond mere petroleum specialisation and into both energy-intensive process industries such as metals, historically nurtured by cheap hydroelectricity, and fisheries, fish-farming and pulp and paper. All these are industries inherently characterised by process rather than product innovations.

Distinctive institutional features include a comparably weak and statedominated banking system, unable to play the co-ordinating roles of the national banking systems in Sweden or Finland (Halvorsen et al (1996)); the lack of strong systems of private industrial ownership and comparably weak markets for venture capital (Baygan (2003)). These characteristics are reflected in data on ownership as the relationship between low levels of domestic private ownership, and high levels of state and foreign portfolio and direct ownership.

Of the two big companies in the petroleum and natural gas extraction and refinement industry, Statoil and Norsk Hydro, the state controls $82 \%$ and $43 \%$ respectively, of equity. In the major telecommunications company Telenor the state has direct control of $78 \%$ of the equity. Of the firms quoted on the Oslo Stock Exchange the state owns 39\% of the shares, domestic financial and industrial agents own $25 \%$ and foreign agents $28 \%$.

When interpreting data on the Norwegian knowledge and industrial system it is important to keep in mind such national characteristics. This of course in particular applies for cross-country comparisons. There are few economies in the world that are so clearly specialised, and it is plau- 
sible to argue that low measured private sector $R \& D$ expenditures at least in part is a reflection of a very large number of small firms in sectors that inevitably will invest comparatively smaller proportions of turnover or profits in R\&D. A weakness in measurable industry innovation input (R\&D) does not necessarily imply a non-innovative industry.

\section{Iceland}

Iceland is different from the other Nordic countries in notably one respect: its size in terms of population. Iceland has barely 300.000 inhabitants. Thus, Iceland has a very small internal market. This poses restrictions on local expansion but also forms a stimulus for many companies to internationalize. Due to its small population Iceland does not have many big firms relative to the other Nordic countries. Its main economic sector is fisheries. While competition is low in many sectors, this is to be expected in a remote economy as small as Iceland's. Minimum efficient economic scale dictates high concentration or even monopoly conditions in many sectors. The economy is also generally open to competition through international trade and foreign direct investment, except in energy, agriculture and fisheries.

\section{Sweden}

As in other countries most companies in Sweden are small. However Sweden has in contrast to Iceland, Norway, and Denmark a relatively great number of large firms and multinational firms. Machinery and equipment, instruments, and transport equipment is the predominant group of industries for R\&D in Sweden. Much of Swedish R\&D takes place in radio, television, and communication equipment, dominated by Ericsson and Sony-Ericsson. In fact, relatively large companies are responsible for most of Swedish R\&D. For instance, one area where Sweden has relatively more R\&D than OECD19 is in chemical, rubber, plastics and fuel, where pharmaceuticals is produced. Here, AstraZeneca is an important contributor to Swedish R\&D.

Sweden has little state control of enterprises, although it does not belong to the group of countries with the least control. There are few barriers to trade and investment, and low barriers to entrepreneurship. Sweden as well as the other Nordic countries has a trade integration rate of around 30 percent in goods. These figures show the importance of world markets for Sweden. Despite being the largest of the Nordic countries, it has nonetheless the highest integration rate. The historical past with an industry structure consisting to a large extent of exporting firms is thus maintained.

\section{Finland}

In Finland, the business sector is highly concentrated, where large domestic multinational enterprises have a significant role in the national econ- 
omy. The large industrial enterprises, especially in the national industrial strongholds of forestry, engineering and manufacturing, and the electronics industries have markets and production sites around the globe. Internationalisation of these firms is also reflected in Finland's outward foreign direct investments' share of GDP, the growth of which in the second half of the 1990s was remarkable. The share of the manufacturing sector of the corporate $\mathrm{R} \& \mathrm{D}$ is the highest, while the share of the service sector is lower than the EU average. On the other hand, the service sector today covers around two-thirds of GDP, whereas the share of the industry sector is slightly below one-third.

The total number of enterprises in Finland has been increasing since 1995 and currently there are more companies than ever before. The majority of companies (around 93\% in 2002) are classified as micro enterprises - with less than 10 employees. Only 0.3 per cent of the companies (570) employed at least 250 employees in 2002. The concentration of business activity comes from the fact that the 159 largest companies by turnover stood for 41 per cent of the total turnover of the enterprise sector in 2002 .

\section{Denmark}

The Danish industry structure is dominated by small firms, as in most other countries. Approximately $90 \%$ of all private companies have less than 10 employees. However, though the majority of firms are small, most of the employment is generated by bigger firms, which also hold most of the assets of the private city industries. The fact that the assets of the private city industries are highly concentrated on relatively few firms has great importance for the average financial strength of private companies, and thus on the average ability of these firms to undertake expensive $\mathrm{R} \& \mathrm{D}$ projects.

According to the OECD's definition of firms' technology level, Danish firms are mostly low technology. The share of total turnover of medium and high technology firms was only about 10 per cent in 2001 (see Danish Ministry of Science, Technology and Innovation (2003)). If one considers also firms within the so called knowledge-service industries, which are mainly counselling, analysis and marketing firms, the share of knowledge intensive firms in the total private sector turnover increases from about 10 per cent to about 16 per cent (see Ministry of Science, Technology and Innovation (2003)). 



\section{Appendix C: Some measurement caveats}

The most common indicator of the input side to the knowledge system is $\mathrm{R} \& \mathrm{D}$ expenditures relative to GDP. The measure has extracted widespread interest in efforts to increase R\&D and innovations in economic systems. As an example, the EU countries have set as a target in the socalled Barcelona declaration from the summit in Barcelona in March 2002 that R\&D expenditures should approach 3\% of GDP by year 2010 with an approximate contribution from the private sector of $2 / 3$.

While there might exist good reasons to focus on $R \& D$ expenditures as a means of increasing innovations and growth in a society, the measure is not without problems. First it measures not output nor the value nor the quality of the possible innovations that R\&D may lead to. Second, R\&D is not the only input into the knowledge system and hence not the only source of innovations. Activities such as learning by doing, design, and product engineering are conducted in most cases on the basis of new technology coming out of $R \& D$. On a larger scale successful $R \& D$ is not only the result of high expenditures to R\&D, but also a result of industry, economic and social structures. Third, R\&D expenditures poorly represent technology development investments in small firms that do not have a distinct $R \& D$ unit. Fourth, the growing importance of non-R\&D innovations in the service sector is not well captured by this measure. Finally, the reported R\&D expenditures by firms may be flawed because the widespread use of public tax incentives to promote $R \& D$ give firms an incentive to report non- $R \& D$ expenditures as $R \& D$ expenditures.

The reason for centering attention on $R \& D$ expenditures is first of all the obvious one that they are easily available from several sources, that they have been reported for almost 40 years, and they are straightforwardly understood. Furthermore, it provides to some extent a consistent basis for comparisons across industries and countries.

Even though R\&D expenditures may not be a precise indicator it should still be kept in mind, the problems notwithstanding, that $R \& D$ expenditures are an important input to the knowledge system. It is hard to argue that substantial advances in technology and processes would be undertaken without systematic expenditures to the knowledge system.

As a typical measure on the output side in the knowledge system is the number of patents. A patent is an intellectual property right granted by a patent office to a firm, an individual or a public institution which gives the applicant a temporary monopoly of the invention. Patent can further- 
more be considered as a crude indicator of the extent to which the knowledge produced is put to commercial use.

Patents are as such one of the best measures at disposal. There are however, some problems that one should be aware of when using patent data as an indicator of innovation. First, not all inventions are patented. Companies can and frequently do, choose other means of protecting their invention for instance by keeping it secret if it is commercially sensitive, or by using trademarks, copyrights, or design restrictions. Cohen et al (2000) and OECD (2005) both find that the use of patent applications as a means of protection is small relative to the total use made of protection methods. OECD (2005) finds this to be particularly true in services and for small firms. Hence, indicators based on patent data will tend to underestimate the actual innovations being made in general and in particular for services and small firms. Second, the number of patens as such does not tell anything about the quality and value of the patent. A way to overcome this problem is to look for other related measures. A typical measure is the so-called triadic patents. Triadic patents are patents that have been applied for and granted at the European Patent Office (EPO), the Japanese Patent Office (JPO), and the United States Patent and Trademark Office (USPTO). To obtain a triadic patent is thus much more costly than to obtain a patent in a specific country, and triadic patents can thus be seen as a proxy for higher quality and value of the invention. Third, patents are only an intermediate measure of output from the knowledge system. Many patents may never be implemented commercially. Furthermore, companies may use patents to protect their own inventions from being made obsolete by other firms' inventions. By patenting a wide array of possible ways of providing the same service or patenting slight improvements of their own product, companies may be able to prevent competition from new products. Finally, when considering patents as a measure of output from the public sector, notably universities and public research organizations, it should be noted that at least in the Nordic countries it has just very recently been an objective of these institutions to seek patents.

In spite of the possible problems with patent data that tend to underestimate the true level of innovations, and overestimate the value, it is still one of the best measures that are at disposal in measuring the output from at least the business sector's R\&D efforts. 


\section{Appendix D: Short descriptions of the public knowledge system in the Nordic countries}

The following describes very briefly the main characteristics of the public knowledge system in each of the Nordic countries.

\section{Denmark}

There are 12 universities, 18 university hospitals, 15 government research institutes, 10 authorized technological service institutes, 21 centers for higher education, and 14 vocational academies.

Universities have access to a wide variety of sources of funding. The most important sources are base research appropriations and the so called student taxi-meter, which depends on the universities' numbers of students. A second major source of funding is grants from e.g. research councils to specific research projects. A third major source of funding is government appropriations for rental and use of buildings.

Copenhagen University has the highest number of students and scientific personnel. This university takes in about a quarter of all university students in Denmark and employs about a quarter of all university scientific personnel. On the other hand, some of the more specialized universities, such as the IT University and the Pharmaceutical University account for only a small fraction of the students and the scientific personnel.

By the very recent University Act from June 2003 universities are self-owned institutions with very specific overall objectives stated in the University Act.

The objectives are to perform research and research based education at the highest international level within their fields of expertise, and they should disseminate their knowledge of scientific results and methods to the wider community. Although the overall objectives are set by the parliament through the University Act, the universities have a great deal of autonomy in setting the operational objectives.

A university is led by a board of directors, which is appointed by the universities themselves according to procedures, which each university develops. The board consists of a majority of external members and a minority of internal members such as scientific personnel and technical and administrative personnel. The chairman of the board is an external board member. 
The board sets strategic objectives and priorities for the university. The strategic objectives and priorities are approved by the Minister of Science, Technology and Innovation. The strategic objectives and priorities are specified in performance contracts between the university and the Minister of Science, Technology and Innovation. There are no examples of the use of performance contracts in the evaluation of universities' performance yet. The chancellor is the top university manager and is hired by the board. The chancellor hires deans and the deans' hire head of departments. Thus the collegiate system is by the new University Act replaced by a management system.

The research council structure consists of two research councils that act as both advisory bodies and funding bodies. One is the so-called "Council for Independent Research" that is based on bottom-up ideas and the other is the "Strategic Research Council" that funds research based on political top-down priorities. Both councils have a board of directors consisting of recognized researchers. In addition there are a number of research specific councils organized under the Council for Independent Research and some multidisciplinary program committees under the strategic council. Finally there is the Danish National Research Foundation that is an independent foundation which finances major research activities based on bottom-up ideas and develops centres of excellence within major programs. As a main counseling body for research policy, there is the Danish Council for Research Policy, and a newly established council for innovation: The Council for Technology and Innovation.

Finally, there exist a number of institutions which provide facilities for entrepreneurs and innovative companies like science parks and socalled innovation incubators which help companies assess the commercial potential of R\&D projects. They can also co-finance R\&D projects on the state's behalf if they deem the projects economically sound. These framework institutions take part in knowledge transfer with companies and knowledge institutions through employee circulation, but they have no independent $\mathrm{R} \& \mathrm{D}$ activities.

\section{Finland}

The Higher Education sector covers altogether 20 universities and a network of polytechnics (29): Ten multi-faculty universities, three universities of technology, three schools of economics and business administration and four art academies. The universities are responsible for higher education and basic research while the polytechnics training professionals. In addition, Finland has 19 government research institutions.

Universities are regulated according to the University Act of 1997 and an amendment in 2004. The overall aim is to further the free research, to teach at the highest level based on research, and to prepare the students for serving the mother country and mankind. The universities shall per- 
form the tasks in cooperation with the civil society and promote the research results' power of penetration to society.

A university is led by a senate where some are elected by faculty and staff and up to one third are external members. The chancellor is elected by the electorate collegiate for a period of five years. However, the chancellor could be an external person to the university. He or she is required to possess a doctorate degree or have been appointed professor at some point in time.

Universities have access to a wide variety of sources of funding. The most important sources are base research appropriations. The appropriations are granted according to a performance agreement. A second major source of funding is grants from e.g. research councils to specific research projects.

The Finnish research, technology development and innovation policy making system has remained almost unchanged over twenty years, since the founding of the National Technology Agency of Finland, Tekes in 1983 and the establishment of the Science and Technology Policy Council in 1987. The Science and Technology Policy Council is the highestlevel policy and coordinating body in the respective field. The main tasks of the Council include directing and coordinating science and technology policy, dealing with the overall development of scientific research and education, and issuing statements on the allocation of public science and technology funds to the various ministries and fields. The Council is chaired by the Prime Minister. The members are the Minister of Education, the Minister of Trade and Industry, the Minister of Finance, four other ministers, and ten other members well versed in science or technology (representatives of the Academy of Finland, Tekes, industry and employers' and employees' organisations).

At the level of the central government, The Ministry of Trade and Industry and the Ministry of Education are the key actors in science, technology and innovation policy formulation and implementation of targets in R\&D activities. The Ministry of Trade and Industry is responsible for technology policy and provides support for industrial research and development.

The National Technology Agency, Tekes has a central position in formulation and implementation of technology policy. It is the principal source of public funding for applied technological research and industrial R\&D. Tekes prepares, funds and co-ordinates national technology programmes, and provides funds for applied technical research and riskcarrying $R \& D$ ventures in industry. It also contributes to the preparation of national technology policy. Tekes has a regionally comprehensive domestic organisation that acts in conjunction with the Employment and Economic Development Centres. In 2004, Tekes provided funding for 2,242 research and development projects in companies, universities and research institutes. The total budget for these projects was 798 million 
euros, of which Tekes financed 409 million euros. In 2004, 28 per cent of all Government research funding was channelled through Tekes.

The Academy of Finland, which includes four national research councils, is responsible for financing and strategy formulation for basic research, research training and science policy. The financing function is carried out through individual projects, programmes, centres of excellence, research posts and research training. In 2004, approx. 14 per cent (EUR 224 million) of all Government research funding were channelled through the Academy. The Academy's responsibilities also include the advancement of scientific research and the encouragement of its exploration, and the development of international scientific co-operation. In its strategy (2003), the Academy underlines the importance of investing in education and research as a key to achieving national success. The Academy is also committed to promoting the development of Finnish society, to implementing the European Research Area and to strengthening global co-operation in such a way that it supports the developing information and education society.

The state research institutes are responsible for applied and missionoriented research in their respective administrative fields. The R\&D institute sector is large by international standards. In total, R\&D activities carried out by state research institutes and public administration corresponds to about 11 per cent of total R\&D expenditure.

\section{Iceland}

Iceland has 10 universities where a number are relatively small and specialized given Iceland's population of a little less than 300.000. Four of these are to be merged this year. In addition, it has 12 public research institutions.

Universities are regulated according to the Universities Act no. 136 December 1997. The main objectives are not as such stated in the act but "A university shall provide students with the education to independently pursue scholarly projects, innovation and fine arts, and to perform various work for society for which higher education is required. Universities shall disseminate knowledge to the general public and provide society with services by means of their knowledge" (Universities Act no. 136 December 1997, article 2).

A university is led by a senate. The senate has up to ten members including the vice-chancellor (rector) who is chairman of the senate. Up to five representatives of the university faculty has a seat in the senate. Students up to two members and the Minister of Education appoints up to two representatives. The Senate nominates a Vice-chancellor to the Minister of education who appoints him or her. The nomination from the senate is based on application for the position. Within the university, the Senate is empowered to decide the organization. 
In 1994 the Icelandic Research Council was established to replace the previous Council of Science (basic research) and National Research Council (applied R\&D). A new legislation on the organisation of science and technology policy and the funding of research and technological development in Iceland was enacted by the Parliament (Althing) at the end of January, 2003.

The legislation is composed of three separate laws:

- Law on the Science and Technology Policy Council under the Office of the Prime Minister

- Law on Public Support to Scientific Research under the Ministry of Education, Science and Culture

- Law on Public Support to Technology Development and Innovation in the Economy under the Ministry of Industry and Commerce

This resulted in the new Science and Technology Policy Council (SPTC) headed by the Prime Minister replacing the Icelandic Research Council (from 1994). The Council provides for the permanent seat of three other ministers, the Minster of Education and Science, the Minister of Industry and Commerce and the Minister of Finance. Fourteen other members are appointed to the Council through nominations from higher education institutions, labour market organisations and other resort ministries. The mission of the STPC is to strengthen scientific research, scientific training and technology development in the country in support of Icelandic cultural development and increased economic competitiveness

The Law on Support to Scientific Research establishes the Research Fund. The Research Fund is governed by a board, whose chairman is also the chairman of the Science Board. Linked to the same board is also the Instrument Fund financed by $20 \%$ annual levies on the University Lottery net income. Similarly the Law on the Support to Technology Development and Innovation has lead to the establishment of a Technology Development Fund which is governed be a board chaired by the Chairman of the Technology Board. The administrative services to the operational level of the whole structure are provided by the Icelandic Centre for Research - Rannís which is the secretariat of the previous Icelandic Research Council. Its mission is to give administrative and operational support to the boards and funding bodies, to manage the international connections, monitor the effects and impacts of policies and to provide intelligence and informed advice to the STPC and its boards and subcommittees. Rannís administers all the funding bodies. Rannís functions as the operational arm of the new council structure. The new law also provides for the establishment of an Innovation Centre, IceTec. The Centre fills a major function by establishing co-operation among public bodies which comprise the support network for innovation in the economy and which shape and operate support projects tailored for small and me- 
dium-sized enterprises and individuals, particularly in regard to the realisation of new business ventures. The current structure is visualized in figure D. 1

The current organisation of the innovation policy delivery structure ensures the link between policy and implementation through funding. The changes in the innovation governance have made innovation an interministerial issue; moreover innovation has become a matter of political responsibility. Coordination within the structure takes place formally but also informally. Ad-hoc meetings depending on whether urgent issues occur take place frequently. A certain degree of flexibility in problemsolving and decision making is herewith provided.

Figure D.1 Organisational chart of the innovation governance system

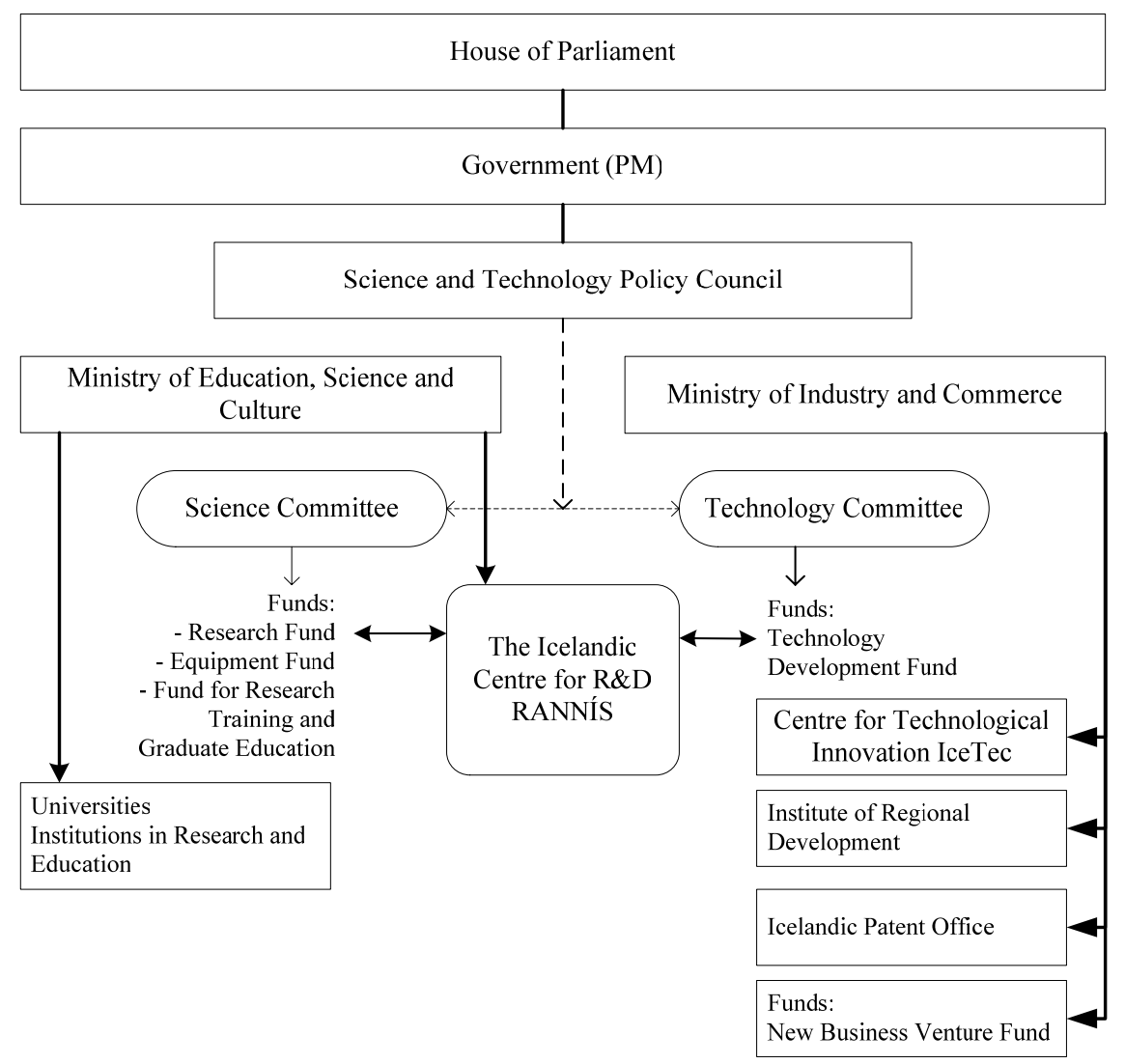

Source: Finnbjørnsson and Verbeek (2005).

\section{Norway}

There are 6 universities, 4 specialized university institutions, 2 national academies of art, 26 university colleges and 21 private colleges in Norway. Norway has a small vocational sector that is not part of the definition of higher education in Norway, in contrast to the definitions of higher education in the other Nordic countries. 
Universities have access to a wide variety of sources of funding. The most important sources are base research appropriations. The appropriations are granted according to a performance agreement. A second major source of funding is grants from e.g. research councils to specific research projects.

University objectives are among other things to provide higher education on the basis of the foremost scientific research, artistic development work and empirical knowledge. Institutions involved in higher education and research shall cooperate and complement each others' academic activities. The institutions are responsible for disseminating knowledge of their activities and for promoting understanding and application of scientific methods and results in public administration, cultural life and business and industry. The overall objectives are set by the parliament through the Act relating to Universities and Colleges (1995, amended in 2002). However, the universities have a great deal of autonomy in setting the operational objectives.

A university is led by a board that consists of eleven members: four academic representatives (including the rector and pro-rector), one representative from the technical and administrative staff, two student representatives, and four external members appointed by the Ministry of Education and Research. The external members often have a background from industry, business, culture, politics, or public organizations. The Board is headed by the chancellor of the institution. The members of the Board are elected for a term of four years, except for the two student representatives, who are elected for one year. Thus Norway has a collegiate system. However, a proposal to a new university law has been presented to the National Assembly in February 2005. At the moment it has not been passed yet. It is proposed that the chancellor could be hired and not elected but that the individual university is to decide what it finds suit it best.

Norway has a large institute sector which has been developed since World War II. Approximately one fourth of total R\&D expenditures are spend in this sector. The largest is The Foundation or Scientific and Industrial Research (SINTEF).

Norway has only one research council. It is a national funding and strategic body. It performs advice to the government and gives funding to both strategic and independent research programs. It is divided into three divisions: The division for science, the division for strategic priorities, and the division for innovation.

\section{Sweden}

In Sweden, there exist 14 state owned universities and 22 state owned university colleges. There are also three university colleges not owned by the state but by foundations with the right to conduct research and therefore have doctoral education, another 10 university colleges with the ex- 
amination rights in undergraduate education and some additional education providers only in psycho-analytics. The university colleges do not always and are not always allowed to undertake research. They are usually smaller and do not embody all faculties.

Sweden do not have a long tradition of science and innovation policy. The science and innovation policy is conducted by two ministries: The Ministry of Education and Science and The Ministry of Industry, Employment, and Communication.

Sweden has reorganized its research council structure and funding structure from 2001. There are now two main funding bodies and research councils: The Swedish Research Council, and VINNOVA (The Swedish Agency for Innovation Systems). In addition, a number of smaller funding agencies exist for more specific disciplines of multidisciplinary research within more narrow frames. Another major source of financing is The Knowledge Foundations which was established in 1994 using money from "The wage earners fund" that was closed down by the conservative government.

Sweden's institute sector is miniscule by international standards; it only represents about 3 percent of public research funds. Instead, the HE system takes on tasks which are normally to a larger extent the job of the institute sector in other countries, such as more applied types of research and dissemination of research results and continued education. Thus, the HE-sector carries through tasks that are more or less politically driven. 


\section{Appendix E: An econometric investigation of the Patents-R\&D relationship for Denmark}

\section{Introduction}

Patent counts are commonly used as output indicators of innovative activity and technical change (see e.g. Griliches, 1990). This is not surprising, given the availability of data and the amount of information they contain. The R\&D expenditures, in turn, are often viewed as an innovation input. It is however recognized that R\&D measure only a fraction of this output. It is also recognized that patents may differ greatly in their economic value, since the distribution of values of patents is very dispersed and skewed (see the surveys by Scherer and Harhoff, 2000 and Scherer, 1998).

A large body of literature has tried to study patents as indicators of output of R\&D. This literature goes back to Pakes and Griliches (1980), Hausman et al. (1984) or Hall et al. (1986). More recently, several studies tried to identify other determinants of patenting activity at the firm level, e.g. Licht and Zoz (1998), Hall and Ziedonis (2001) or Ziedonis (2004).

We now briefly summarize what the earlier work in this area has found:

- Patents are an output to R\&D rather than an input, as it had been sometimes argued. (Hall et al., 1984)

- $\mathrm{R} \& \mathrm{D}$ and patents are dominated by a strong contemporaneous relationship rather than lags (Hall et al., 1984)

- There is a general agreement that $R \& D$ expenditures and firm size have a strong positive effect on patenting activity, even if some studies found that small firms tend to patent more by unit of R\&D than large firms (Pavitt, 1985).

- Other determinants like export activities have a more ambiguous effect on patents, since some studies find a strong relationship between them (Licht and Zoz, 1998), whereas other studies find only a weak correlation (Zimmerbach and Schwalbach, 1991).

- The determinants of patenting have changed over time. In industries using "complex" technologies, firms use patents for defensive reasons and are involved in portfolio races. Hall and Ziedonis (2001) studied this phenomenon in the semiconductor industry in the US. 
Our analysis builds on this literature to study the patents-R\&D relationship by using a matched patents-R\&D database for Denmark in 2001 and applying Zero-Inflated count models, to take into account the heterogeneity due to the large number of firms that did not apply for patents in 2001.

\section{Sample and Data}

The database used for this analysis results from the merge of the R\&D data and data from the CEBR Patent Database, containing information on all patent applications by Danish firms at the European Patent Office (EPO) since its creation in 1978. Kaiser and Schneider (2004) provide details on how the database has been constructed.

The CEBR Patent Database provides two patent application dates; the "priority date" - the date at which the patent applicant first sought patent protection either at some national patent office or the EPO - and the "application date" - the date at which the patent applicant sought patent protection at the EPO. The two dates only coincide if the patent application directly went to the EPO without a prior application to a national patent office. Our analysis uses the priority date as the relevant time stamp since this date is closest to the invention date.

We do not have information on patents applied by Danish firms elsewhere, e.g. the Danish Patent Office (DKPTO) or any other national patent office, if this application is not followed by an EPO application. The cost of applying for a patent is however much higher at the EPO than at the DKPTO, we then expect these firms to apply for their more valuable inventions at the EPO and the less valuable ones at the DKPTO.

By merging our two databases, we were able to identify 90 firms that had applied for at least one patent in 2001, out of 497 in the patent database. The remaining firms in the R\&D database (2102, after having cleaned the database) have not applied for any patent in 2001. Figure E1 shows the distribution of the number of patents applied by the Danish firms in the matched R\&D-patents database, conditional on having applied for at least one patent.

Our base specification of the patent production function includes the following variables, for which summary statistics are given in table E1:

\section{Dependent variable:}

The total number of patents applied for in 2001, at the EPO or with subsequent application at the EPO. (i.e. patents applied for at the EPO, with priority year 2001)

\section{Explanatory variables:}

Total R\&D expenditures in 2001 (in DKK 1000; in logs) ${ }^{9}$

\footnotetext{
${ }^{9}$ Due to the fact that some firms report that they did not make any R\&D expenses in 2001, the variable is defined as $\log (R \& D+1)$
} 
Figure E1 Distribution of patent applications

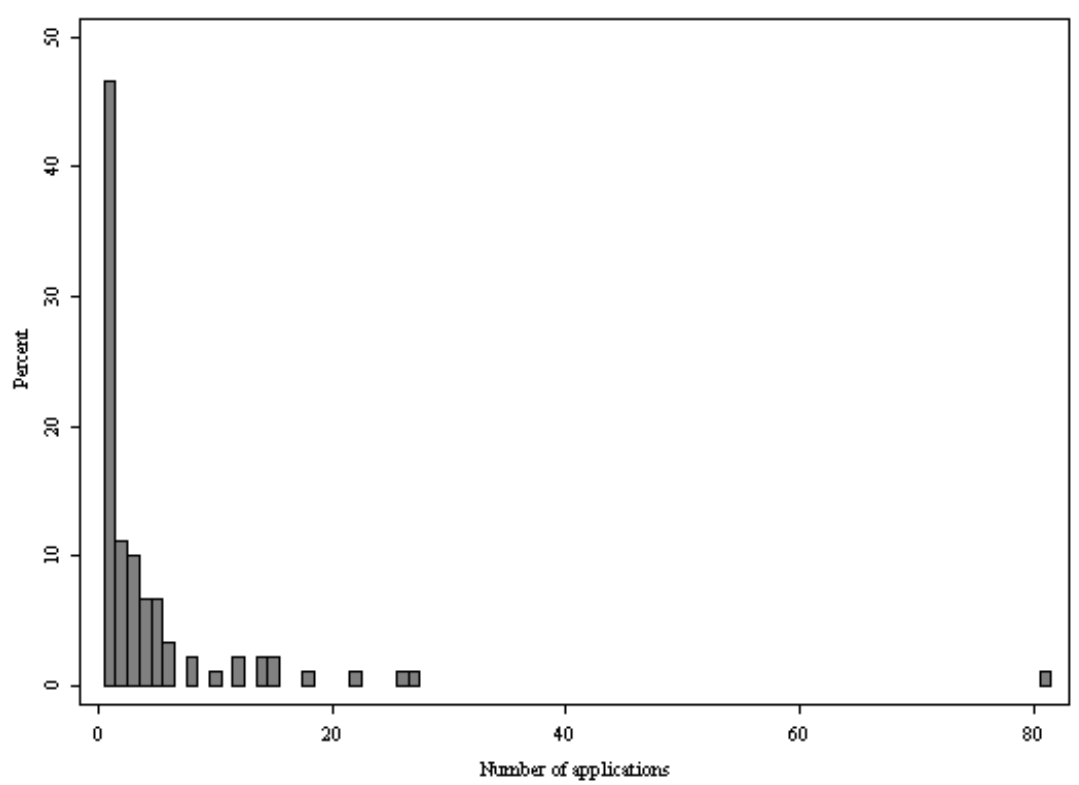

The size of the firms, measured as the number of employees in 2001 (in logs)

The amount of fixed assets (in DKK 1000; in logs)

A dummy variable that indicates if the firm is in a "complex" product industry. We follow the classification by Cohen et al. (2000). In complex product industries, an invention is comprised of numerous separately patentable elements, whereas in "discrete" product industries, a new invention only requires a limited number of patents. Industries with NACE codes above 2900 (machinery, computers, electrical equipment, electronic components, instruments, and transportation equipment) where coded as complex.

A dummy variable for stock-listed firms, that indicates if the firm has an " $A / S$ " legal structure.

A dummy variable that indicates if the firm has made an innovation in 2001. We can see from table E1 that some firms applied for a patent in 2001 but report no innovation. There could be 2 reasons. The first one is that the innovation has been made the year before (2000) whereas the patent has been applied for in 2001. The other reason could be that the firms bought an innovation to second party, which can be a university, another firm, an individual inventor, etc. The dummy variable takes the value 1, only if the firms has made an innovation itself.

A dummy variable indicating if the firm has a permanent $R \& D$ department.

The age of the firm in 2001, calculated as the difference between 2001 and the date at which the firm has been founded. 
Table E1 Descriptive statistics

\begin{tabular}{|c|c|c|c|c|c|c|c|c|}
\hline \multirow[b]{2}{*}{ Variable } & \multicolumn{4}{|c|}{ Patenting firms } & \multicolumn{4}{|c|}{ All firms } \\
\hline & Mean & SD & Min. & Max. & Mean & SD & Min & Max \\
\hline \# applications & 3.493 & 7.346 & 1 & 81 & 0.046 & 0.932 & 0 & 81 \\
\hline $\log (1+R \& D)$ & 7.681 & 4.076 & 0 & 14.263 & 0.990 & 2.563 & 0 & 14.263 \\
\hline Log size & 4.652 & 1.715 & 2.079 & 8.820 & 2.806 & 1.134 & 0.693 & 9.501 \\
\hline Log fixed assets & 18.830 & 1.951 & 15.708 & 24.151 & 16.149 & 1.513 & 11.429 & 25.000 \\
\hline Age in 2001 & 18.645 & 16.659 & 3 & 119 & 16.798 & 12.021 & 0 & 145 \\
\hline$E G$ & 0.060 & 0.046 & -0.0003 & 0.232 & 0.036 & 0.052 & -0.014 & 0.729 \\
\hline RDSI (\%) & 0.495 & 0.289 & 0.006 & 0.796 & 0.433 & 0.294 & 0.006 & 0.796 \\
\hline RSI & 1.416 & 0.967 & 0.406 & 7.321 & 1.202 & 1.071 & 0.026 & 12.851 \\
\hline $\mathrm{D} A / \mathrm{S}$ & 0.922 & 0.268 & & & 0.603 & 0.489 & & \\
\hline D innovation & 0.009 & 0.098 & & & 0.125 & 0.331 & & \\
\hline D Complex & 0.741 & 0.438 & & & 0.767 & 0.422 & & \\
\hline D R\&D dpt & 0.587 & 0.493 & & & 0.064 & 0.246 & & \\
\hline \# obs. & \multicolumn{4}{|c|}{90} & \multicolumn{4}{|c|}{2192} \\
\hline
\end{tabular}

The Ellison-Glaeser index (EGI) that measures the degree of geograpchical concentration to which a given industry is geographically concentrated (in terms of employment) in a given location.

The share of employees in the region where the firm is based, which work in the $R \& D$ sector (RDSI).

\section{Econometric methodology: models for count data}

Due to the nature of the dependant variable (the number of patent applications), which is positive and only takes integers values, we use count models to investigate the patents-R\&D relationship. We use the patent production function proposed by Pakes and Griliches (1980) and Hausman et al. (1984).

\section{Poisson and Negative Binomial models}

Suppose that the functional form of the expected number of patent applications is exponential:

$$
E\left[n_{i} \mid X_{i}\right]=\lambda_{i}=\exp \left(X_{i} \beta\right)
$$

The simplest assumption traditionally made is that the data generating process follows a Poisson distribution:

$$
\operatorname{Pr}\left[n_{i}=N_{i} \mid X_{i}\right]=\frac{\exp \left(-\lambda_{i}\right) \lambda_{i}^{n_{i}}}{n_{i} !}
$$

With: $n_{i} \geq 0$ and $E\left[n_{i} \mid X_{i}\right]=\operatorname{Var}\left[n_{i} \mid X_{i}\right]=\lambda_{i}>0$

The assumption that the data follow a Poisson distribution implies that the mean equals the variance. In most cases, the count variable is greater than the mean, which is a violation of the Poisson distributional assumption. That is, the model underestimates the amount over overdispersion in the outcome. 
A way to overcome this problem is to use the Negative Binomial specification, by assuming that the Poisson parameter follows a Gamma distribution $\widetilde{\lambda}=\exp \left(X_{i} \beta+\varepsilon_{i}\right)$. The distribution of $n_{i}$ can then be shown to be Negative Binomial:

$$
\operatorname{Pr}\left[n_{i}=N_{i} \mid X_{i}\right]=\frac{\Gamma\left(n_{i}+v_{i}\right)}{\Gamma\left(n_{i}+1\right) \Gamma\left(v_{i}\right)}\left(\frac{v_{i}}{\phi_{i}+v_{i}}\right)^{v_{i}}\left(\frac{\phi_{i}}{\phi_{i}+v_{i}}\right)^{n_{i}}
$$

With: $E\left[n_{i} \mid X_{i}\right]=\phi_{i}=\exp \left(X_{i} \beta\right)$ and $\operatorname{Var}\left[n_{i} \mid X_{i}\right]=\phi_{i}+\frac{\phi_{i}^{2}}{v_{i}}$

If we set $v_{i}=\alpha^{-1} \phi_{i}$ we get the so-called NegBin I model specification, with the variance $\operatorname{Var}\left[n_{i} \mid X_{i}\right]=(1+\alpha) E\left[n_{i} \mid X_{i}\right]$ which leads to a constant variance-to-mean ratio.

Similarly, the NegBin II model is obtained by setting $v_{i}=\alpha^{-1}$, which implies a different form of heteroscedasticity:

$$
\operatorname{Var}\left[n_{i} \mid X_{i}\right]=E\left[n_{i} \mid X_{i}\right]\left[1+\alpha E\left[n_{i} \mid X_{i}\right]\right]
$$

In this case, the variance-to-mean ratio is linear in the mean.

\section{Zero-Inflated models}

In addition to overdispersion, count data and especially patent data, often have the characteristic to be overabundant of zeros. The Poisson and Negative Binomial models need to be modified, in order to take account of the "excess zero" feature. We briefly present the Zero Inflated Poisson (ZIP) and Zero Inflated Negative Binomial (ZINB) proposed by Greene (1994). These specifications allow us to model the excess zeros by using the mixture of a distribution for positive outcomes (modeled as a Poisson or a Negative Binomial distribution) and the zeros.

Suppose that:

$$
\begin{aligned}
& n_{i}=0 \text { with probability } q_{i} \\
& n_{i} \sim \operatorname{Poisson}\left(\lambda_{i}\right) \text { with probability } 1-q_{i}
\end{aligned}
$$

As before we assume that $\lambda=\exp (X \beta)$. In addition, we specify the probability weight as a logit CDF:

$$
q_{i}=\frac{\exp \left(Z_{i} \delta\right)}{1+\exp \left(Z_{i} \delta\right)}
$$

and consider a process whereby the observed variable, $n$, is generated as:

$$
n_{i}=z_{i} n_{i}^{*}
$$


where $z_{i}$ is a binary variable, and $n_{i}^{*}$ is distributed as Poisson or Negative Binomial. The ZIP and ZINB models are then given by:

$$
\begin{aligned}
& \operatorname{Pr}\left[n_{i}=0\right]=q_{i}+\left(1-q_{i}\right) f(0) \\
& \operatorname{Pr}\left[n_{i}=k\right]=\left(1-q_{i}\right) f(k), \quad f(k)>0
\end{aligned}
$$

Where $f($.$) is the Poisson or Negative Binomial distribution for n_{i}^{*}$.

There are a huge number of firms for which no patent application has been registered in 2001. There are firms that are not willing to apply for patents, whereas there are others for which the number of applications might follow more conventional patterns amenable to a Poisson or Negative Binomial regression, but might, once again be zero. However, the actual number is observable only if a firm decides to apply for a patent.

There is a substantial difference between a decision to apply for patents and the decision to increase the number of applications. The former decision reflects the propensity to patent. The latter captures the extent to which the firm applies for patents. Zero-Inflated models capture both these aspects by estimating a combined qualitative regression that explains the decision to apply or not for patents, and a quantitative regression that explains the extent to which firms apply for patents.

Besides Zero-Inflated models, hurdle models are commonly applied in count data with excess zeros. The basic idea is that the participation decision and the positive counts are generated by separate processes. For patent applications, the decision model for applying or not for patents is generally specified by a logit or probit model. The second part is a truncated at zero count model that only focuses on firms with a positive number of patent applications. See Winkelmann and Zimmermann (1995) or Licht and Zoz (1998) for an application to patent data.

\section{Results}

Table E2 shows the estimation results for the Poisson and Negative Binomial models. Since the variance of the count variable is almost 19 times greater than the mean, a Negative Binomial specification might be preferable to the Poisson model, which requires that the mean equals the variance. The overdispersion parameter $(\alpha)$ is significantly positive. This is confirmed by the Likelihood-Ratio (LR) test that rejects the pure Poisson model. All the models indicate a strong positive effect of $R \& D$ and firm size measured as the number of employees, which is consistent with the previous studies. We also find that firms with a permanent R\&D department and firms with an A/S legal structure were more likely to patent than their competitors. More surprisingly, we find that the fixed assets elasticity is significantly negative and that the effect of innovative firms does not have a significant effect on the number of patent applications.

As the LR test has shown, the model presents overdispersion, which can be caused by individual heterogeneity and/or excess zeros. $96 \%$ of 
the firms did not apply for a patent in 2001. This issue can be dealt with, by using the Zero-Inflated models presented in section 3 .

Table E. 3 presents the result from the Zero-Inflated models. Again, the Negative Binomial specification is favored by the LR test, after the excess zero issue is addressed. Moreover, the Bayesian and Akaike Information criterion (BIC and AIC) provide very strong support for the ZINB model, against any of the other model (Poisson, NB and ZIP).

Table E2 Poisson and Negative Binomial models

\begin{tabular}{|c|c|c|c|}
\hline \multicolumn{4}{|l|}{ Variables } \\
\hline Log R\&D & $0.598(0.023) * * *$ & $0.380(0.027)$ *** & $0.466(0.030) * * *$ \\
\hline Log size & $0.775(0.037)^{* * *}$ & $0.737(0.065) * * *$ & $0.804(0.086) * * *$ \\
\hline Log fixed assets & $-0.573(0.015)^{* * *}$ & $-0.434(0.025) * * *$ & $-0.545(0.031)^{* * *}$ \\
\hline Age in 2001 & $0.006(0.002)^{* * *}$ & $-0.006(0.007)$ & $0.005(0.007)$ \\
\hline EG & $0.612(0.958)$ & $2.839(1.340)$ ** & $1.252(1.819)$ \\
\hline RDSI & $71.489(15.232) * * *$ & $12.943(23.803)$ & $40.628(33.457)$ \\
\hline RSI & $0.118(0.030)^{* * *}$ & $0.023(0.059)$ & $-0.080(0.094)$ \\
\hline D A/S & $0.248(0.117)^{* *}$ & $0.392(0.201)$ * & $0.877(0.241)^{* * *}$ \\
\hline D innovation & $0.855(0.434)$ ** & $-1.034(0.705)$ & $0.118(0.444)$ \\
\hline D Complex & $-0.895(0.077)^{* * *}$ & $-0.594(0.147)^{* * *}$ & $-0.539(0.216)$ ** \\
\hline D R\&D dpt & $0.715(0.093) * * *$ & $0.631(0.149) * * *$ & $0.799(0.207) * * *$ \\
\hline$\alpha$ & & $5.697(0.848)$ & $9.188(1.153)$ \\
\hline LR test for overdispersion & & $1017.79^{* * *}$ & $1040.78^{* * *}$ \\
\hline Log-likelihood & -1673.049 & -1164.157 & -1132.533 \\
\hline \multirow{2}{*}{$\begin{array}{l}\text { BIC/AIC } \\
\text { \# observations }\end{array}$} & $-13431.396 / 1.537$ & $-14441.489 / 1.073$ & $-14464.483 / 1.063$ \\
\hline & \multicolumn{3}{|c|}{2192} \\
\hline
\end{tabular}

Weighted observations

Standard errors in parenthesis

BIC/AIC: Bayesian Information Criteria/Akaike Information Criteria

${ }^{* \star *} p<0.01$

${ }^{* *} p<0.05$

$* p<0.1$

Note that different patterns may govern the decision to apply or not for a patent (the binary part) and the decision to increase the number of applications (the count model). This fact is reflected when the signs in both parts of the model are different. It is also important to note that the firms' strategies play a crucial role, in addition to the economic environment and the individual characteristics, as we are going to see.

$R \& D$ expenses and firm size turn out to be major sources in generating new knowledge. The elasticities of the number of patents with respect to $R \& D$ and with respect to firm size are increasing with the current value of these variables: the number of patents applied for increases with R\&D and firm size. The coefficient indicates that for a $1 \%$ increase in $R \& D$ expenditures, the number of patents applied for would increase by about $0.47 \%$, whereas the same increase of the number of employees would result in $0.58 \%$ more patents. In addition, $R \& D$ and firm size have also a positive impact in the decision part: the probability to apply for at least one patent increases with firm size and the amount of R\&D expenses. 
Stock-listed firms (A/S legal structure), patent on average $128 \%$ $(=\exp (0.826)-1)$ more than other firms, but the effect of the dummy variable is insignificant in the decision stage. A possible interpretation of this result is that $\mathrm{A} / \mathrm{S}$ firms have a better knowledge on the manner to manage intellectual property and get access to other appropriability mechanisms.

As expected, firms having innovated in 2001 are more likely to apply for a patent and do it to a larger extent. These firms patent on average 261 times more than the other firms. The effect of the variable is strongly significant in both stages of the model.

Table E3 Zero-Inflated models

\begin{tabular}{|c|c|c|c|c|}
\hline \multirow[b]{2}{*}{ Variables } & \multicolumn{2}{|r|}{ ZIP } & \multicolumn{2}{|r|}{ ZINB } \\
\hline & Logit & Poisson & Logit & $\begin{array}{l}\text { Negative } \\
\text { Binomial }\end{array}$ \\
\hline \multirow[t]{2}{*}{ Log R\&D } & 0.119 & 0.573 & 0.303 & 0.471 \\
\hline & $(0.069)^{* *}$ & $(0.050) * * *$ & $(0.142)^{* * *}$ & $(0.038) * * *$ \\
\hline \multirow[t]{2}{*}{ Log size } & -0.610 & 0.369 & 4.269 & 0.578 \\
\hline & $(0.093)^{* * *}$ & $(0.045)^{* * *}$ & $(1.203) * * *$ & $(0.098) * * *$ \\
\hline \multirow[t]{2}{*}{ Log fixed assets } & 0.111 & 0.426 & -6.998 & -0.466 \\
\hline & $(0.496)^{* *}$ & $(0.029)^{* * *}$ & $(1.737)^{* * *}$ & $(0.035) * * *$ \\
\hline \multirow[t]{2}{*}{ Age in 2001} & 0.022 & 0.014 & 0.033 & 0.004 \\
\hline & $(0.007)^{* * *}$ & $(0.002) * * *$ & $(0.037)$ & $(0.007)$ \\
\hline \multirow[t]{2}{*}{ EG } & -5.193 & -2.721 & -50.756 & -1.854 \\
\hline & $(2.257)^{* *}$ & $(1.263)^{* *}$ & $(14.434)^{* * *}$ & $(2.050)$ \\
\hline \multirow[t]{2}{*}{ RDSI } & 26.219 & 52.151 & -624.618 & -18.810 \\
\hline & (36.779) & $(23.670) * *$ & $(278.146)^{\star *}$ & $(49.009)$ \\
\hline \multirow[t]{2}{*}{ RSI } & 0.041 & 0.031 & -0.005 & -0.063 \\
\hline & $(0.109)$ & $(0.041)$ & $(0.662)$ & $(0.109)$ \\
\hline \multirow[t]{2}{*}{ D A/S } & 0.743 & 1.195 & 1.224 & 0.826 \\
\hline & $(0.377)$ & $(0.187)^{* * *}$ & $(1.218)$ & $(0.300)^{* * *}$ \\
\hline \multirow[t]{2}{*}{ D innovation } & 5.805 & 5.751 & 124.467 & 5.565 \\
\hline & $(0.930)^{* * *}$ & $(0.687)^{* * *}$ & $(30.952)^{* * *}$ & $(1.224)^{* * *}$ \\
\hline \multirow[t]{2}{*}{ D Complex } & 0.482 & -0.145 & 108.932 & 0.734 \\
\hline & $(0.217)^{* *}$ & $(0.093)$ & $(27.374)^{* * *}$ & $(0.198) * *$ \\
\hline \multirow[t]{2}{*}{ D R\&D dpt } & -0.419 & 0.318 & -3.521 & 0.372 \\
\hline & $(0.201)$ & $(0.135) * *$ & $(1.178)^{* * *}$ & $(0.253)$ \\
\hline$\alpha$ & & & & $4.862(0.693)$ \\
\hline LR test for overdispersion & & & & 220 *** \\
\hline McFadden $\mathrm{R}^{2} /$ Cragg \& Uhler $\mathrm{R}^{2}$ & & $0.391 / 0.626$ & & $0.336 / 0.518$ \\
\hline $\mathrm{BIC} / \mathrm{AIC}$ & -14 & $30.303 / 1.144$ & -14 & $663.936 / 0.943$ \\
\hline Log-likelihood & & -1126.385 & & -1010.624 \\
\hline \# observations & & 21 & & \\
\hline$\#$ applications $=0$ & & 96 & & \\
\hline
\end{tabular}

Weighted observations

Standard errors in parenthesis

BIC/AIC: Bayesian Information Criteria/Akaike Information Criteria

${ }^{* \star *} p<0.01,{ }^{* *} p<0.05,{ }^{*} p<0.1$

In the same way, the signs of the coefficients for firms active in industries using "complex" technologies are positive and significant in both stages of the model. this confirms the argument by Hall and Ziedonis (2001) that firms in these sectors are engaged in portfolio races and that their high patenting rate can be explained by defensive reasons. In complex tech- 
nology industries, innovations are typically highly cumulative (they build on prior art) and complementary, which implies that firms patent more aggressively in these sectors. In our model, firms using complex technologies apply, an average of approximately $108 \%$ more patents than other firms in the sample.

Having a R\&D department, as well as the share of employees working in the R\&D sector in the region where the firm performs, has negative impacts in the decision part and an insignificant impact in the number of applications. This result can be interpreted in the same way, i.e. firms with permanent $R \& D$ activities and with a pool of potential employees working in the R\&D sector, have a better knowledge about alternative ways to protect their inventions.

The most surprising result is that the fixed assets have a negative impact on both stages of the model. A possible explanation could be that the Danish industry structure is dominated by large firms in fairly lowtechnology industries which do not patent much.

The Ellison-Glaeser index has a negative impact on the decision to apply for a patent but the elasticity of the number of applications is insignificant.

Finally, the age of the firm and the regional specialization have an insignificant impact on both stages of the model.

\section{Conclusion}

Patent data have been and still are widely used by economists as indicators of innovative activity of a country or a firm. The above analysis intended to explain the patenting behavior using Danish data and applying Zero-Inflated count models. We now briefly summarize the main findings of this analysis.

First and foremost, our analysis confirms the importance of the traditional determinants of patenting activity, namely $R \& D$ expenditures and firm size. R\&D turns out to be a major source in generating new knowledge, although the elasticity of the number of patents, with respect to R\&D with our data is lower than studies that use American data (e.g. Hausman et al., 1984), German data (Licht and Zoz, 1998) or French data (Crépon and Duguet, 1996).

Secondly, our results reflect the growing importance of patents as a strategic tool. Hall and Ziedonis (2001) as well as Cohen et al. (2000), found that firms in industries using "complex" technologies, firms create "thickets" of complementary and/or cumulative patents to reduce the "holdup" problem posed by external patent owners. Our results confirm these earlier results, by showing that firms in complex technology industries patent more than in other sectors.

Our results also highlight another strategic aspect, which resides in the appropriability mechanism to protect inventions. Cohen et al. (2000), found out that patenting is among the firms' least preferred appropriabil- 
ity mechanism, with large differences between industries, far behind trade secrecy for instance. Several of our results seem to confirm this result. Firms having a permanent $R \& D$ department have a lower propensity to patent, which can be interpreted by the fact that these firms have a better knowledge of alternative appropriability mechanism to protect their inventions.

Analyzing patent data as indicators of innovation is complex given the rapid change in patenting behavior over the last decade. The rapid growth in patenting that took place in Denmark in particular (see Kaiser et al., 2005 ) and worldwide in general (see, e.g., OECD, 2004) needs to be further investigated to see if this mirrors technological change and innovation, but the fact that we were restricted to a single cross section sample did not allow us to go deeper in this analysis. Further research is currently undertaken using the CEBR Patent Database, using Danish data, to investigate unresolved issues regarding patents and innovation (see Kaiser and Schneider, 2004).

\section{References}

Cohen, W.M., Nelson, R.R. and Walsh, J.P. (2000) "Protecting Their Intellectual Assets: Appropriability Conditions and Why US Manufacturing Firms Patent (or not)" NBER Working Paper 7552.

Greene, W. (1994) “Accounting for Excess Zeros and Sample Selection in Poisson and Negative Binomial Regression Models" Department of Economics Working Paper EC-94-10, Stern School of Business, New York University.

Griliches, Z. (1990) "Patent Statistics as Economic Indicators: A Survey" Journal of Economic Literature, 28() 1661-1707.

Hall, B. H., Griliches, Z. and Hausman, J. (1986) "Patents and R\&D: Is There a Lag?" International Economic Review, 27(2) 265-283.

Hall, B.H. and Ziedonis, R. H. (2001) "The Patent Paradox Revisited: An Empirical Study of Patenting in the US Semiconductor Industry, 19791995" RAND Journal of Economics, 32(1) 101-128.

Hausman, J.A., Hall, B.H. and Griliches, Z. (1984) "Econometric Models for Count Data with an Application to the Patents-R\&D Relationship" Econometrica, 52() 909938.
Kaiser, U., Licht, G., Rønde, T. And Schneider, C. (2005) "Patenting Activity in Denmark", Centre for Economic and Business Research (CEBR) Discussion Paper, DP 2005-09.

Kaiser, U. and Schneider, C. (2004) "The CEBR matched patent/patent Applicant/employee data base: part 1 - patent data", mimeo. CEBR Discussion paper; available at: http://www.ulrichkaiser.com/papers/p atentdesc.pdf.

Licht, G. and Zoz, K. (1998) "Patents and R\&D. An Econometric Investigation Using Applications for German, European and US Patents by German Companies" Annales d'Économie et de Statistique, 49/50 495-516.

OECD (2004) "Compendium of Patent Statistics" OECD, Paris.

Pakes, A. and Griliches, Z. (1980) "Patents and R\&D at the Firm Level: A First Look" Economic Letters, 5() 377-381.

Pavitt, K. (1985) "Patent Statistics as Indicators of Innovative Activities: Possibilities and Problems" Scientometrics, 7() 77-99.

Scherer, F.M. (1998) "The Size Distribution of Profits from Innovation" Annales d'Économie et de Statistique, 49/50 495-516. 
Scherer, F.M. and Harhoff, D. (2000) "Technology Policy for a World of Skew-Distributed Outcomes" Research Policy, 29() 559-566.

Winkelmann, R. and Zimmermann, K. F. (1995) "Recent Developments in Count Data Modelling: Theory and Application" Journal of Economic Surveys, 9() 1-24.
Ziedonis, R.M. (2004) “Don't Fence Me In: Fragmented Markets for Technology and the Patent Acquisition Strategies of Firms" Management Science, 50(6) 804-820.

Zimmerbach, K. F. and Schwalbach, J. (1991) "Determinanten der Patentaktivität" ifo-studien, 37() 201-227. 



\section{Appendix F: Svend E. Hougaard Jensen's presentation at seminar in the Danish Ministry of Finance 16 September 2005}

Only available electronically:

http://www.norden.org/pub/sk/showpub.asp?pubnr=2005:586 